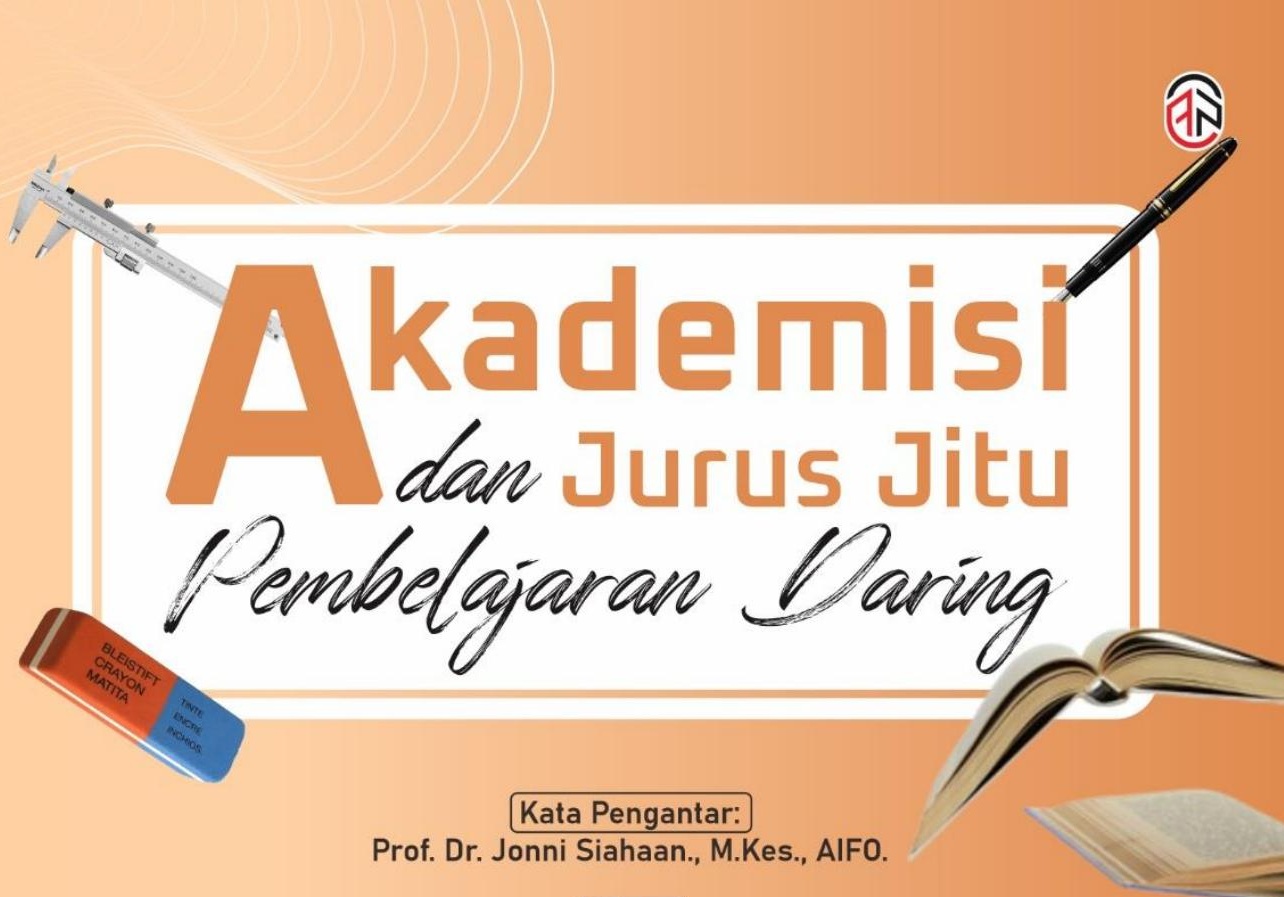

\title{
Editor:
}

Dr. Adi Wijayanto, S.Or., S.Kom., M.Pd., AlFO.

Dr. Anita, S.S., M.Pd.

Ulfah Mey Lida, M.Pd.

Dr. Aria Septi Anggaira, M.Pd

Iffat Maimunah | Adelina Citradewi | Baskoro Nugroho Putro | Netty Herawaty Purba Nurul Nitasari | Siti Rodi'ah | Maria Andriani Barek Ladjar | Emy Putri Alfiyah | Sufiana Noor

M.A Yohanita Nirmalasari | Ita Rakhmawati | Saidna Zulfiqar Bin Tahir Katharina E.P Korohama | Nirwaning Makleat | Melifera Yani Makleat | Corneli Gaite Sukarman Hadi Jaya Putra | Agep Rumanto | Salisa Maulidiyah | MarianusYufrinalis Mariana Ikun RD Pareira | Hiljati | Yulianti Wulandari | Aulia Novemay Dhita Rahmadyah Kusuma Putri | Abdul Khamid | Prima Nanda | Eka Kurnia Darksman Anik Widayanti E.W.T | Hamzah

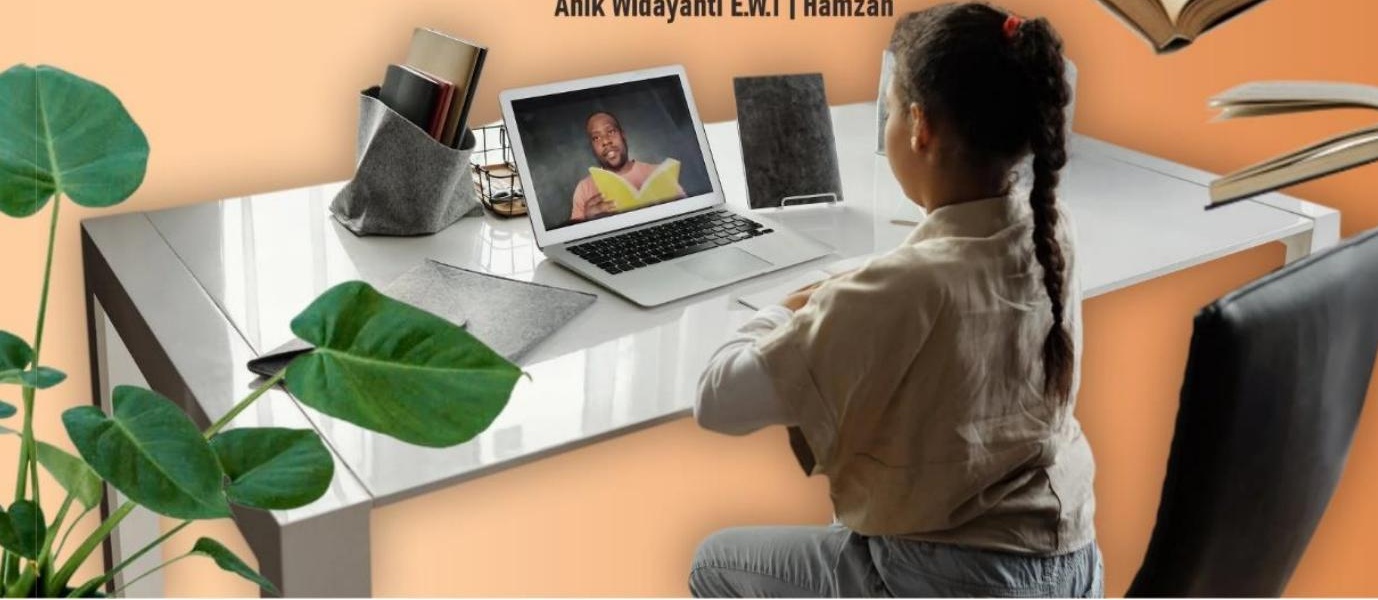




\section{AKADEMISI DAN JURUS JITU PEMBELAJARAN DARING}

Iffat Maimunah | Adelina Citradewi | Baskoro Nugroho Putro | Netty Herawaty Purba | Nurul Nitasari | Siti Rodi'ah | Maria Andriani Barek Ladjar | Emy Putri Alfiyah | Sufiana Noor

| M.A Yohanita Nirmalasari | Ita Rakhmawati |

Saidna Zulfiqar Bin Tahir | Katharina E.P Korohama |

Nirwaning Makleat | Melifera Yani Makleat | Corneli Gaite | Sukarman Hadi Jaya Putra | Agep Rumanto | Salisa Maulidiyah|

Marianus Yufrinalis | Mariana Ikun RD Pareira | Hiljati | Yulianti Wulandari | Aulia Novemy Dhita | Rahmadyah Kusuma Putri | Abdul Khamid | Prima Nanda | Eka Kurnia Darisman | Anik Widayanti E.W.T | Hamzah |

\section{Editor:}

Dr. Adi Wijayanto, S.Or., S.Kom., M.Pd., AIFO.

Dr. Anita, S.S., M.Pd.

Ulfah Mey Lida, M.Pd.

Dr. Aria Septi Anggaira, M.Pd

\section{Kata Pengantar:}

Prof. Dr. Jonni Siahaan., M.Kes., AIFO. 


\section{AKADEMISI DAN JURUS JITU PEMBELAJARAN DARING}

Copyright (C) Iffat Maimunah, dkk., 2021.

Hak cipta dilindungi undang-undang

All right reserved

Editor: Adi Wijayanto, dkk

Layout: Kowim Sabilillah

Desain cover: Diky M. Fauzi

Penyelaras akhir: Saiful Mustofa

viii+ 237 hlm: 13,5 x 20,5 cm

Cetakan Pertama, Juni 2021

ISBN: 978-623-6364-00-0

\section{Anggota IKAPI}

Hak cipta dilindungi undang-undang. Dilarang mengutip atau memperbanyak sebagian atau seluruh isi buku ini tanpa izin tertulis dari penerbit.

Diterbitkan oleh:

\section{Akademia Pustaka}

Perum. BMW Madani Kavling 16, Tulungagung

Telp: 081216178398

Email: redaksi.akademia.pustaka@gmail.com

Website: www.akademiapustaka.com 


\section{KATA PENGANTAR}

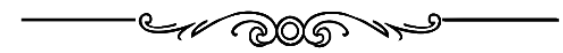

Presiden Republik Indonesia bersama Menteri
Pendidikan dan Kebudayaan Riset dan Teknologi sangat mengharapkan peringatan Hardiknas sebagai momentum untuk wujudkan program merdeka belajar secara serentak di Indonesia. Program merdeka belajar ini sangat diharapkan dapat menciptakan loncatan-loncatan dalam pengembangan pendidikan di tanah air sehingga menghasilkan sumber daya manusia (SDM) unggul yang siap menghadapi era persaingan bebas yang ditandai dengan perkembangan revolusi industri 4.0 dimana salah satu produknya adalah lahirnya teknologi digital dan robotik yang sistem kerjanya masif dan canggih dan diharapkan dapat bersinergis menunjang peningkatan pendidikan di Indonesia.

Seiring dengan tema Hardiknas tahun 2021 maka sangat tepat apabila para pendidik atau akademisi memiliki jurus jitu untuk wujudkan proses belajar yang profesional meskipun tetap menjaga diri dari penyebaran virus corona. Akademisi sangat diharapkan memiliki kemampuan mengembangkan proses belajar secara daring di sekolah dan selanjutnya dijadikan acuan bagi anak didik dan diberi kebebasan dalam mengembangkan proses belajarnya secara mandiri di rumah sehingga target belajar yang hendak dicapai dapat terwujud, meskipun ada dugaan bahwa selama pandemi Covid-19 ini sangat mungkin terjadi penurunan kualitas anak didik karena salah satu penyebabnya yaitu masih sulitnya menciptakan proses belajar yang optimal secara daring, tanpa dipantau 
langsung para guru seperti proses belajar tatap muka di sekolah.

Pemikiran-pemikiran yang cerdas dari berbagai pakar pendidikan dan akademisi yang telah dijabarkan dalam tulisan-tulisan telah memperkaya isi buku Bunga Rampai "AKADEMISI DAN JURUS JITU PEMBELAJARAN DARING" sehingga para guru sedikitbanyaknya dapat menggunakannya sebagai dasar berpikir untuk mensukseskan proses belajar daring di rumah anak didik. Selanjutnya dengan mempertimbangkan bahwa wabah pandemi covid-19 yang belum tahu pasti kapan berakhirnya, maka berbagai sumbangan pemikiran dari para pakar pendidikan yang ada dalam buku Bunga Rampai ini bisa menjadi opsi bagi para guru, anak didik, sekolah dalam mengambil kebijakan terkait proses belajar daring. Demikianlah sebagai pengantar yang menjadi dasar pemikiran betapa pentingnya buku Bunga Rampai ini untuk dibaca para guru, anak didik dan masyarakat.

Jayapura, Mei 2021

Prof. Dr. Jonni Siahaan., M.Kes., AIFO. Guru Besar Universitas Cenderawasih Papua 


\section{DAFTAR ISI}

KATA PENGANTAR ............................................................... iii

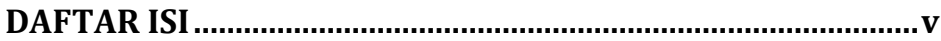

BAB I: DISRUPSI PEMBELAJARAN DARING .............................1

MEMBANGKITKAN ONLINE ACADEMIC WRITING SKILL

DI ERA COVID-19

Oleh Iffat Maimunah, M.Pd .3

IMPLEMENTASI CONTEXTUAL TEACHING AND LEARNING PADA PEMBELAJARAN PASAR MODAL GUNA MENUMBUHKEMBANGKAN MINAT BERINVESTASI MAHASISWA DI ERA PANDEMI COVID-19

Oleh Adelina Citradewi, S.Pd., M.Ak. 13

OPTIMALISASI KETRAMPILAN BERTANYA UNTUK MENINGKATKAN PARTISIPASI PESERTA DIDIK DALAM PEMBELAJARAN DARING

Oleh Baskoro Nugroho Putro, M.Pd.

EFEKTIFITAS PENGGUNAAN APLIKASI BELAJAR TIDAK BERBAYAR DALAM PROSES PEMBELAJARAN DARING PADA MATA KULIAH ASUHAN KEBIDANAN KEHAMILAN Oleh Netty Herawaty Purba, SST., M.Keb

MENUMBUHKEMBANGKAN KEPERCAYAAN DIRI PESERTA DIDIK DALAM PRAKTIK BERPIDATO DI ERA PEMBELAJARAN DARING

Oleh Nurul Nitasari, M. Pd 37

INOVASI PEMBELAJARAN DARING MELALUI PEMANFAATAN HASIL PENELITIAN

Oleh Siti Rodi'ah, S.Pd.I

OPTIMALISASI PEMAHAMAN MAHASISWA MATA KULIAH EVALUASI PEMBELAJARAN PENJASORKES MELALUI STRATEGI PEMBELAJARAN DARING

Oleh Maria Andriani Barek Ladjar,S.Si., M.Pd 
EDUKASI DINI PENDIDIKAN MODERASI BERAGAMA PADA KEGIATAN PONDOK RAMADHAN DI TINGKAT MADRASAH

Oleh Emy Putri Alfiyah, S.Th.I 59

MENUMBUHKAN ENTREPRENEURSHIP INTENTION

MAHASISWA MELALUI PEMBELAJARAN DARING

Oleh Sufiana Noor, M.M.

EKSISTENSI ILMU KIMIA DAN PEMBELAJARANNYA

DALAM MASA PANDEMI

Oleh M.A Yohanita Nirmalasari, S.Si., M.Pd

ANALISIS AKUNTANSI KEPERILAKUAN PADA

PEMBELAJARAN PROGRAM STUDI AKUNTANSI

Oleh Ita Rakhmawati

BAB II: REALITA PEMBELAJARAN DARING 87

PENGEMBANGAN MODEL PEMBELAJARAN ONLINE PADA MASA PANDEMI COVID-19 DI DAERAH 3T DI MALUKU Oleh Dr. Saidna Zulfiqar Bin Tahir, Lc., M.Pd., Ph.D

GAMBARAN SOFT SKILL MAHASISWA

DI TENGAH PANDEMI COVID 19

Oleh Katharina E.P Korohama, S.Pd., M.Pd

POTRET PENDIDIKAN NON FORMAL DALAM BINGKAI PANDEMI COVID-19

Oleh Nirwaning Makleat, S.Si.,M.Pd

CORONA VIRUS DISEASE DALAM EVOLUSI PENDIDIKAN DI NUSA TENGGARA TIMUR

Oleh Melifera Yani Makleat, S.Si.,M.Si

DINAMIKA PEMBELAJARAN DI PSDKU ARU PADA MASA PANDEMI COVID-19

Oleh Corneli Gaite, M.Pd

DAMPAK PENDIDIKAN KEWIRAUSAHAAN PADA GELIAT USAHA TANAMAN HIAS DI MASA PANDEMI COVID-19 Oleh Sukarman Hadi Jaya Putra, S.Pd., M.Si. 
PERGESERAN PERAN DOSEN DALAM

ERA OVERLOAD INFORMATION

Oleh Agep Rumanto, M.E

PEMBELAJARAN DARING DI MASA PANDEMI COVID-19

Oleh Salisa Maulidiyah, M.Pd

MENAKAR KESIAPAN DAN PARTISIPASI PESERTA DIDIK DALAM PEMBELAJARAN DARING SELAMA MASA PANDEMI COVID-19 DI KABUPATEN SIKKA, NTT

Oleh Marianus Yufrinalis, S.Fil., M.A

BAB III: PSIKIS, NILAI DAN KARAKTER

PEMBELAJARAN DARING

UDKUNGAN PSIKOSOSIAL BAGI MAHASISWA DI MASA PANDEMI COVID-19

Oleh Mariana Ikun RD Pareira, M.Psi.T

PROSES PEMBELAJARAN DARING DAN PEMBENTUKAN KARAKTER PESERTA DIDIK

DI MASA PANDEMIK COVID 19

Oleh Hiljati, S.Ag.,M.Pd,I. 165

PEMBELAJARAN DARING MELATIH KEMANDIRIAN DAN PENDEWASAAN PROSES BELAJAR MAHASISWA DI MASA PANDEMIK

Oleh Yulianti Wulandari, SKM.,MARS. 175

SEBUAH DIALOG: PENDIDIKAN KARAKTER DAN PEMBELAJARAN SEJARAH BERBASIS DARING

Oleh Aulia Novemy Dhita, M.Pd 183

MEMBANGUN LITERASI MEMBACA MAHASISWA MELALUI PENUGASAN STUDI KASUS DAN INFOGRAFIS PADA

PEMBELAJARAN JARAK JAUH

Oleh Rahmadyah Kusuma Putri, M.Pd

PERSEPSI DAN EKSPEKTASI PEMBELAJARAN JARAK JAUH (PJJ) DI ERA WABAH PANDEMI COVID-19

Oleh Abdul Khamid, M.Pd 
WADAH OLAHRAGA REKREASI NAGARI

PAUAH LUBUK SIKAPING

Oleh Prima Nanda, S.Pd., M.Pd

207

BENTUK LATIHAN MENTAL DALAM PERKULIAHAN

DI MASA PANDEMI

Oleh Eka Kurnia Darisman, S.Pd., M.Pd...................................... 213

PERAN GURU DALAM MEMOTIVASI KEBERANIAN

BERTANYA PESERTA DIDIK PADA

PEMBELAJARAN DARING

Oleh Anik Widayanti E.W.T, S.Psi, M.Psi....................................... 221

PERSEPSI MAHASISWA PRODI PENDIDIKAN BAHASA ARAB INSTITUT AGAMA ISLAM DDI POLEWALI MANDAR

TENTANG PEMBELAJARAN DARING DI MASA

PANDEMI COVID-19 TA. 2020-2021

Oleh Dr. Hamzah, S.S., M.Pd.I.

229 


\section{BAB I: \\ DISRUPSI PEMBELAJARAN DARING}

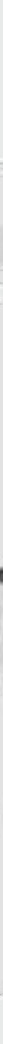




\title{
MEMBANGKITKAN ONLINE ACADEMIC WRITING SKILL DI ERA COVID-19
}

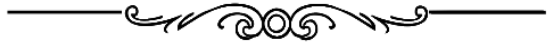 \\ Iffat Maimunah, M.Pd1 \\ UIN Maulana Malik Ibrahim Malang
}

"Meski kehadiran dosen tidak bisa tergantikan dalam proses

transfer ilmu, namun setidaknya online library dan pengenalan tool reference manager dapat menunjang pengembangan ilmu bagi mahasiswa dan mendukung academic writing skill."

Skill menulis karya ilmiah merupakan kebutuhan mendasar bagi mahasiswa. Setiap mahasiswa tidak dapat menghindari aktivitas menulis, sejak ia memulai studi di perguruan tinggi. Demikian pula setiap mata kuliah yang diprogram dalam perkuliahan meniscayakan mereka menguasai dan memahami materi dengan baik dan mengimplementasikan dalam wujud tulisan. Meski ceramah merupakan metode yang tidak bisa ditinggalkan oleh dosen, namun demikian membaca diktat kuliah, mereview dan menulis makalah turut serta menyempurnakan proses belajar mahasiswa. Terlebih lagi jika diskusi menjadi kegiatan rutin yang dijalankan dalam perkuliahan, maka menulis makalah dan membuat slide PPt menjadi piranti

1Penulis lahir di Balung Jember, 27 Mei 1979. Penulis sebagai pengajar di UIN Maulana Malik Ibrahim Malang. Aktif dalam kegiatan academic writing, baik sebagai narasumber atau peserta. Kegiatan academic writing menuntunnya untuk terus belajar dan produktif dalam berkarya. 
perkuliahan yang harus disiapkan dan tidak boleh diabaikan.

Moment kebersamaan seorang dosen dengan mahasiswa dalam proses penyelesaian tugas dan kewajiban perkuliahan, menjadi momentum yang dapat memberikan support system dalam hal tulis menulis. Maka mengenalkan tehnik dasar menulis karya ilmiah menjadi sebuah tuntutan yang harus ditunaikan oleh seorang dosen. Bermula dari penyampaian materi perkuliahan secara teoritis dan normatif, maka pengenalan aspek empiris hendaknya juga menjadi sebuah ihtiar yang harus dilakukan untuk melengkapi tujuan perkuliahan yang berbasis outcome. Dengan demikian, praktek menulis makalah atau karya ilmiah merupakan kebutuhan yang tidak bisa ditawar, dan niscaya menjadi materi utama yang disampaikan oleh dosen, dan hendaknya dipahami oleh mahasiswa (Sianipar, 2018).

Apalagi dalam masa pandemi COVID-19, terhitung sejak bulan Maret 2020 telah dinyatakan sebagai bencana global yang harus menjadi kewaspadaan bersama (Wargadinata, et al., 2020), maka kelangsungan segala aktivitas bergeser menuju pada aktivitas virtual. Demikian pula proses pembelajaran di seluruh jenjang pendidikan, harus tetap berjalan dan protokol kesehatan menjadi perhatian yang diprioritaskan (Febriani, 2020). Regulasi kebijakan yang mengharuskan mahasiswa belajar dari rumah dapat dikuatkan dengan gerakan semangat dan giat menulis. Keadaan darurat yang terjadi pada masa pandemi ini telah merubah aktivitas pembelajaran face to face dan digantikan dengan instrumen media belajar online, demikian pula interaksi secara intensif dengan perpustakaan online (online library) akhirnya dilakukan oleh mahasiswa (Wargadinata, et al., 2020). 
Menghadapi fenomena yang demikian, hendaknya tidak menjadikan fokus perkuliahan dilengahkan oleh siapapun, baik oleh dosen dan mahasiswa. Maka, sebagai langkah mendasar adalah menguatkan skill akademik mereka dengan menunjukkan teknik dasar menulis, dan sejalan dengan penguatan tujuan utama perkuliahan berbasis outcome. Dengan memanfaatkan ketersediaan sumber belajar dan referensi online di laman-laman internet, maka menunjukkan dan mengenalkan link sumber rujukan keilmuan menjadi upaya yang harus dilakukan. Dengan kata lain, mahasiswa yang tidak dapat berkunjung ke perpustakaan kampus tetap bisa produktif menulis, meski mereka berada di rumah masing-masing.

Fenomena pandemi COVID-19, melengkapi tantangan global bagi dunia pendidikan secara umum, mulai pendidikan dasar hingga perguruan tinggi (Wargadinata et al., 2019). Mahasiswa dituntut menjalankan aktivitas akademik bergantung pada internet, seiring dengan perkembangan Revolusi Industri 4.0, darurat pandemi juga merubah era ini menuju pada era internet of thing (Junaidi April, 2015), demikian pula dalam mengakses sumber keilmuan, maka ketergantungan pada internet menjadi hal yang tak terbantahkan. Menyikapi keadaan yang sedang berjalan, dengan keharusan interaksi berjarak dalam dunia pendidikan, maka mahasiswa hendaknya giat dan semangat mengenal tool reference manager yang tersedia di laman internet. Memfungsikan dan memanfaatkan on line library dengan maksimal menjadi piranti dasar penulisan karya ilmiah yang dapat membantu mahasiswa dalam menyelesaikan tugas dan kewajiban kuliah (Dulkiah et al., 2020).

Dengan menyadari sepenuhnya atas kehidupan mahasiswa yang bergantung pada internet, akhirnya 
menuntut mereka melek digital, tidak hanya untuk berkomunikasi sehari-hari, akan tetapi internet menjadi sumber keilmuan yang dapat dengan mudah diakses, jika secara real time kebutuhan jaringan dan kuota internet terpenuhi maka siapapun dapat memanfaatkan dengan mudah tanpa ada batas ruang dan waktu. Artinya, produktivitas dalam berkarya sangat mudah diwujudkan jika piranti utama sudah berada di dalam genggaman tangan (Khair, 2015).

Meski kehadiran dosen di ruang virtual tidak bisa tergantikan dalam proses transfer ilmu, namun setidaknya online library dan pengenalan tool reference manager dapat menunjang pengembangan ilmu bagi mahasiswa dan mendukung academic writing skill. Keterbacaan mahasiswa atas online library yang tinggi dapat memenuhi kebutuhan mahasiswa selama masa perkuliahan berlangsung, tidak hanya di masa pandemi tentunya, akan tetapi hingga nanti selama kebutuhan akses referensi dan library masih berlangsung selama masa studi.

Masa pandemi COVID-19 yang memediasi semua umat dengan kebutuhan IT, telah berimplikasi pada pengenalan laman-laman referensi dan online library. Upaya ini setidaknya menjadi jurus jitu bagi pendidik untuk menguatkan academic writing skill kepada mahasiswa. Meski academic writing skill umumnya ditempuh oleh mahasiswa dalam mata kuliah "Bahasa Indonesia" atau mata kuliah "Writing" pada prodi Bahasa Inggris, namun saat ini membangun academic writing skill menjadi gerakan yang selalu didengungkan dan digalakkan secara masif, baik melalui agenda workshop dan pelatihan, atau ruang belajar bersama yang berlangsung secara live streaming di link zoom dan atau link YouTube (Munir \& Supriyatno, 2020). 
Demikian halnya pengenalan tool dan laman online library, secara sederhana sesungguhnya dapat diakses oleh mahasiswa melalui searching di laman google, akan tetapi alangkah baiknya jika mengenalkan laman online library dan tool reference manager ini disampaikan kepada mahasiswa sejak dini (bagi mahasiswa semester satu dan dua), mengingat membangun academic writing skill, menjadi kebutuhan dasar di dunia akademik, dan produktivitas ilmu pengetahuan di kalangan mahasiswa menjadi momentum yang selalu dinantikan (AlMarwani, 2020).

Banyak sekali online library yang dapat membantu mahasiswa dalam melakukan produksi ilmu pengetahuan melalui dunia tulis menulis, dan tidak asing lagi di dunia publikasi. Online library membantu mahasiswa untuk menulis tugas harian, artikel penelitian, tugas akhir, dan publikasi. Database yang terdapat di dalam online library, seperti mendeley desktop atau zotero dilengkapi dengan fitur literature search dan dokumen referensi (GarcíaPuente, 2020). Sehingga pengguna dapat memanfaatkan untuk melakukan pengutipan (sitasi) referensi secara otomatis baik dengan model innote atau footnote, dan disempurnakan dengan pencantuman daftar bibliografi secara otomatis. Di antara laman online library yang dapat diakses dengan mudah oleh mahasiswa adalah Google Scholar, ScienceDirect, Library Genesis, Academia, Researchgate, Wiley Online Library, Indonesian Publication Index, Perpustakaan Nasional (Francavilla, 2018), dan tentunya masih banyak lagi yang lain.

Menguatkan academic writing skill bagi mahasiswa hendaknya dilalui pula dengan mengenalkan teknik penelitian sederhana yang bertujuan untuk memenuhi komponen penulisan makalah dan artikel ilmiah (Meza \& 
González, 2020). Dalam penelitian dapat dijelaskan model penelitian, penentuan sumber data, teknik pengumpulan data dan teknik analisa data. Untuk kemudahan dalam praktek penelitian (lapangan) sederhana di masa pandemi COVID-19 ini bisa dijalankan di lingkungan sekitar tempat tinggal mereka, dan tentunya dengan menyesuaikan bidang kajian mereka.

Dengan demikian academic writing skill bagi mahasiswa, sejatinya dapat memacu mahasiswa untuk semangat belajar, dengan kata lain pada saat giat menulis sesungguhnya mahasiswa telah melakukan praktek belajar yang sesungguhnya, dan proses peningkatan self efficacy dapat terwujud secara efektif. Selain academic writing skill bertujuan mengetahui perkembangan scientific atas suatu disiplin ilmu, mereka pun dapat memproduksi perkembangan keilmuan baru, jika karya ilmiah berhasil dipublikasikan maka karya tersebut akan menjadi bangunan keilmuan yang turut membangun sejarah di dunia ilmu pengetahuan.

Disadari atau tidak, ketersediaan online library dan tool reference manager di laman online benar-benar membantu mahasiswa, dan terpenting lagi menjadi penggugah proses menulis. Sehingga, dapat dipastikan jika seseorang telah mengetahui perkembangan scientific, state of the art suatu disiplin ilmu, kemudian dikuatkan dengan pemahaman yang benar atas online library dan tool reference manager, serta didukung kecukupan data yang diperoleh di lapangan, maka mahasiswa dapat dengan mudah menguraikan karya tulis ilmiah, baik sebagai tugas dan kewajiban kuliah, penulisan artikel penelitian, ataupun publikasi ilmiah.

Oleh karena itu, academic writing skill hendaknya menjadi materi utama yang dikenalkan pada masa awal 
studi mahasiswa (Kiriakos \& Tienari, 2018). Meski metode penulisan telah menjadi muatan mata kuliah tertentu yang dipelajari oleh mahasiswa, setidaknya akan lebih baik jika dikenalkan dalam materi pendampingan di awal studi mereka. Sehingga, pada saat proses perkuliahan berlangsung, mahasiswa sudah mengenal dasar-dasar penulisan, memudahkan teknik review artikel ilmiah, dan membuka cakrawala bangunan teori dan keilmuan terdahulu. Maka, sebagai harapan terbesar dari terwujudnya academic writing skill adalah lahirnya ilmuwan yang mampu memproduksi ilmu pengetahuan dari karya ilmiah yang dituliskan. 


\section{Daftar Pustaka}

AlMarwani, M. (2020). Academic Writing: Challenges and Potential Solutions. Arab World English Journal, 6. https://doi.org/10.24093/awej/call6.8

Dulkiah, M., Nurmawan, N., Rohmana, J. A., \& Rahman, A. S. (2020). Adaptasi Mahasiswa Dalam Penggunaan Media on Line Sebagai Dampak Wabah Covid-19. Digital Library UIN Sunan Gudung Djati, 1(1).

Febriani, S. R. (2020). Implementation of Arabic Learning During COVID-19 Emergency in Indonesia: HOTS, MOTS, or LOTS? Alsinatuna: Journal of Arabic Linguistics and Education, 5(2).

Francavilla, M. L. (2018). Learning, teaching and writing with reference managers. Pediatric Radiology, 48(10). https://doi.org/10.1007/s00247-0184175-z

García-Puente, M. (2020). Reference Managers as Day-toDay Tools. Zotero. Pediatria de Atencion Primaria, 22(85).

Junaidi April. (2015). Internet Of Things, Sejarah, Teknologi Dan Penerapannya : Review. Jurnal Ilmiah Teknologi Informasi, IV(3).

Khair, F. (2015). Internet Of Things, Sejarah, Teknologi Dan Penerapannya: Review. Jurnal Ilmiah Teknologi Informasi, IV(3).

Kiriakos, C. M., \& Tienari, J. (2018). Academic writing as love. Management Learning, 49(3). https://doi.org/10.1177/1350507617753560

Meza, P., \& González, M. (2020). Construction and validation of the self-efficacy scale for disciplinary academic writing. Cogent Education, 7(1). https://doi.org/10.1080/2331186X.2020.1830464

Munir, M., \& Supriyatno, T. (2020). Media Daring sebagai Self Directed Learning Materi PAI SD Pada Masa Pandemi Covid-19. Fikrotuna. 
Sianipar, V. M. B. (2018). Pembelajaran Literasi Informasi Terhadap Menulis Karya Ilmiah Sederhana. EDUKASI KULTURA: Jurnal Bahasa, Sastra Dan Budaya, https://doi.org/10.24114/kultura.v1i1.11723

Wargadinata, W., Maimunah, I., Dewi, E., \& Rofiq, Z. (2020). Student's Responses on Learning in the Early COVID-19 Pandemic. Tadris: Jurnal Keguruan Dan Ilmu Tarbiyah. https://doi.org/10.24042/tadris.v5i1.6153

Wargadinata, W., Maimunah, I., Febriani, S. R., \& Humaira, L. (2020). Mediated Arabic Language Learning for Arabic Students of Higher Education in COVID-19 Situation. Izdihar: Journal of Arabic Language Teaching, Linguistics, and Literature. https://doi.org/10.22219/jiz.v3i1.11862

Wargadinata, W., Wahidmurni, W., Abdussakir, A., Wahyuni, E., \& Maimunah, I. (2019). Alternative Education In The Global Era: Study Of Alternative Models of Islamic Education In Tazkia International Islamic Boarding School Malang. Library Philosophy and Practice.

https://doi.org/https://digitalcommons.unl.edu/li bphilprac/3748/ 


\section{IMPLEMENTASI CONTEXTUAL TEACHING AND LEARNING PADA PEMBELAJARAN PASAR MODAL GUNA MENUMBUHKEMBANGKAN MINAT BERINVESTASI MAHASISWA DI ERA PANDEMI COVID-19}

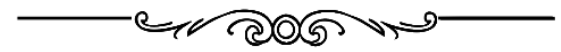

\section{Adelina Citradewi, S.Pd., M.Ak. ${ }^{2}$}

Institut Agama Islam Negeri Kudus

"Dalam konteks pembelajaran pasar modal, dosen selaku tenaga pendidik dapat mengarahkan mahasiswa selaku peserta didik untuk dapat berkontribusi aktif sebagai investor di Bursa Efek Indonesia."

Pandemi covid-19 yang melanda hampir ke seluruh penjuru di dunia membuat adanya perubahan pada aktivitas sosial masyarakat. Pola konsumsi masyarakat menjadi salah satu hal yang bersinggungan dengan adanya status pandemi covid-19 ini. Masyarakat dituntut untuk mampu menyesuaikan segala perubahan yang ada, tanpa terkecuali pada aspek manajemen keuangan. Aspek keuangan merupakan aspek yang menjadi hal yang sangat berpengaruh akibat adanya pandemi covid-19.

2Penulis lahir di Brebes, 02 September 1993, penulis merupakan Dosen IAIN Kudus dalam bidang ilmu Akuntansi, penulis menyelesaikan gelar Sarjana Pendidikan Akuntansi di Universitas Negeri Semarang (2015), sedangkan gelar Magister Akuntansi di Universitas Diponegoro Program Studi Akuntansi (2018). 
Menteri Ketenagakerjaan dalam pidatonya saat acara pembukaan Pelatihan Berbasis Kompetensi (PBK) pada Kamis, 18 Februari 2021 menyampaikan bahwa sebanyak 17,8\% perusahaan melakukan Pemutusan Hubungan Kerja (PHK) selama pandemi covid-19. Beliau menambahkan bahwa sebanyak $25,6 \%$ perusahaan merumahkan pekerjanya dan $10 \%$ perusahaan melakukan kedua hal tersebut. Tingginya angka PHK sebagai dampak dari penurunan volume penjualan menuntut masyarakat untuk cerdas dalam mengelola keuangan yang dimilikinya. Manajemen aset merupakan salah satu alternatif yang dapat dilakukan, khususnya saat meningkatnya ketidakpastian ekonomi dimasa pandemi covid-19. Implementasi tersebut dapat dilakukan dengan menjadikan investasi sebagai pilihan wajib yang dilakukan masyarakat.

Terdapat berbagai macam jenis instrumen investasi yang dapat dijadikan pilihan bagi masyarakat, baik yang berbentuk real asset atau pun financial asset. Investasi yang berbentuk real aset, seperti tanah dan emas masih menjadi pilihan sebagian besar masyarakat di Indonesia karena dianggap memiliki tingkat risiko yang lebih rendah dibandingkan dengan berinvestasi di pasar keuangan, serta lebih stabil dan konsisten terhadap inflasi. Sedangkan investasi pada pasar keuangan dalam bentuk financial asset, seperti deposito, saham, reksadana ataupun obligasi masih menjadi pilihan kedua dibandingkan investasi pada real asset tersebut. Saham merupakan salah satu contoh financial asset yang populer dalam dunia investasi. Saham adalah salah satu instrumen investasi di pasar modal yang merupakan tanda bukti kepemilikan modal atau dana pada suatu perusahaan (Fahmi, 2012). Masyarakat yang memilih saham sebagai instrumen investasinya, maka mereka 
termasuk sebagai pemilik perusahaan tersebut sesuai dengan besaran persentase atas saham yang dimilikunya.

Perguruan tinggi selaku institusi yang menciptakan sumber daya manusia yang unggul dalam menghadapi tantangan di era Society 5.0 dituntut untuk menciptakan metode pembelajaran yang selaras dengan realita zaman. Salah satu metode pembelajaran yang dapat menjadi pilihan adalah metode Contextual Teaching and Learning. Menurut Daryanto (2012) metode Contextual Teaching and Learning adalah suatu proses pendidikan holistik dan bertujuan memotivasi peserta didik untuk memahami makna materi pembelajaran yang dipelajarinya dengan mengaitkan materi tersebut dengan konteks kehidupannya mereka sehari-hari sehingga peserta didik memiliki pengetahuan atau keterampilan yang secara fleksibel dapat diterapkan.

Dalam konteks pembelajaran pasar modal, dosen selaku tenaga pendidik dapat mengarahkan mahasiswa selaku peserta didik untuk dapat berkontribusi aktif sebagai investor di Bursa Efek Indonesia. Hal ini dapat dilakukan dengan melibatkan peran dari perusahaan sekuritas selaku pihak yang menjembatani mahasiswa selaku calon investor dan perusahaan selaku emiten di pasar modal. Adanya kehadiran perusahaan sekuritas yang memfasilitasi calon investor dengan modal awal Rp 100.000 merupakan angin segar bagi investor pemula yang memiliki dana minim untuk berkontribusi dalam meningkatkan jumlah investor pasar modal di Indonesia dan menumbuhkan iklim investasi di masyarakat.

Pada awal tahun 2014, Bursa Efek Indonesia juga telah mengeluarkan aturan konversi jumlah lot saham. Kebijakan perubahan 1 lot saham dari 500 lembar menjadi 100 lembar saham, salah satunya bertujuan untuk 
meningkatkan jumlah investor pasar modal di Indonesia. Selain itu, kampanye "Yuk Nabung Saham" yang dilaunching oleh Bursa Efek Indonesia sejak 12 November 2015 juga bertujuan untuk meningkatkan minat masyarakat dalam berinvestasi di pasar modal. Hal ini dilakukan guna mengubah mindset masyarakat dari saving society menjadi investing society. Hal ini didukung pula dengan wujud nyata kehadiran "Galeri Investasi Bursa Efek Indonesia" pada beberapa perguruan tinggi di Indonesia. Kehadiran Galeri Investasi ini bertujuan untuk mempermudah mahasiswa dalam memperoleh akses, baik informasi seputar pasar modal maupun hubungannya dengan perusahaan sekuritas.

Bursa Efek Indonesia selaku institusi yang menyelenggarakan dan menyediakan sistem jual beli efek telah berupaya untuk memberikan kemudahan akses dan informasi guna meningkatkan minat investasi masyarakat. Penerapan metode Contextual Teaching and Learning dapat diimplementasikan dengan mengintegrasikan konsep pasar modal yang diperoleh selama proses pembelajaran dan peran aktif mahasiswa untuk menjadi "The Real Investor" agar dapat mengaplikasikan konsep yang diperoleh sebelumnya. Selaras dengan hal tersebut, mahasiswa juga akan menjadi angka penyumbang jumlah investor di pasar modal Indonesia.

Menurut data statistik pasar modal dari PT Kustodian Sentral Efek Indonesia (KSEI) yang berlaku sebagai Lembaga Penyimpan dan Penyelesaian (LPP) efek, per Desember 2020 investor di pasar modal Indonesia didominasi oleh 61,58\% laki-laki, 54,9\% usia di bawah 30 tahun, 43,88\% lulusan sarjana, 53,67\% berpenghasilan 10 100 juta Rupiah/tahun dan 71,82\% berdomisili di Pulau Jawa. 


\section{Usia}

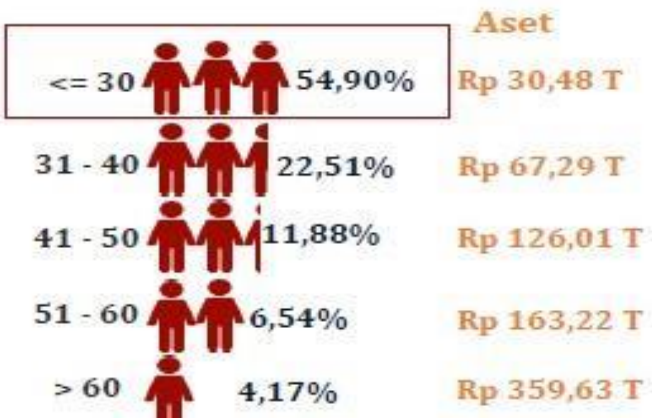

Gambar 1. Demografi Investor Individu Berdasarkan Usia

Selain itu, KSEI juga mencatat bahwa pada tahun 2020 telah terjadi peningkatan jumlah investor di pasar modal. Berikut ini merupakan data statistik jumlah investor di pasar modal dari tahun 2017 hingga tahun 2020.

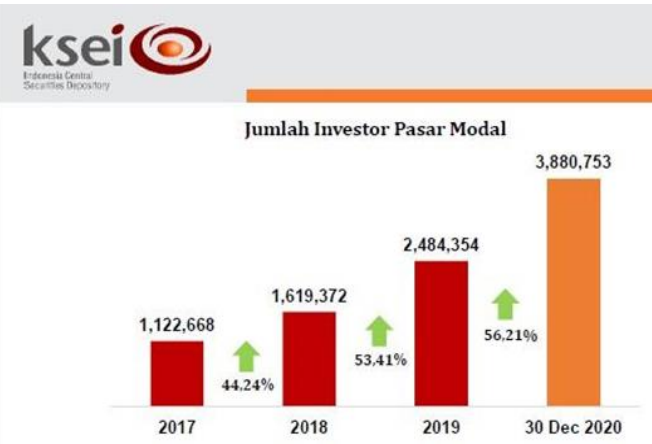

Gambar 2. Jumlah Investor Pasar Modal Tahun 2017-2020

Data tersebut menunjukkan bahwa telah terjadi peningkatan jumlah investor di pasar modal sebesar lebih dari 300\% selama kurun waktu 3 tahun terakhir. Peningkatan ini juga didukung oleh adanya kontribusi dari investor milenial dalam rentang usia di bawah 30 tahun. Tahun 2020, diklaim sebagai tahun kebangkitan investor domestik. Berdasarkan data KSEI dilaporkan bahwa tahun 2020 merupakan tahun dengan jumlah investor domestik 
tertinggi sepanjang sejarah, yaitu menembus angka 56,85\%. Investor milenial dianggap mampu mengangkat laju Indeks Harga Saham Gabungan (IHSG) yang sempat mengalami titik terendahnya sebesar Rp 3.937 saat pandemi virus covid-19 masuk ke Indonesia dan saat ini telah kembali menguat kembali pada level Rp 6.000.

Adanya peningkatan jumlah investor di pasar modal, didukung oleh adanya peran serta dari Bursa Efek Indonesia dan pihak-pihak terkait lainnya. Perguruan tinggi selaku institusi penyelenggara Tri Darma Perguruan Tinggi diharapkan mampu menjadi wadah dalam menciptakan bibit-bibit investor baru melalui proses pembelajaran yang bersifat kontekstual guna menghadapi tuntutan zaman yang semakin tinggi. 


\section{Daftar Pustaka}

Daryanto. (2012). Model Pembelajaran Inovatif. Yogyakarta: Gava Media.

Fahmi, Irham. (2012). Pengantar Pasar Modal. Bandung: Alfabeta.

https://www.merdeka.com/uang/menaker-178perusahaan-phk-karyawan-selama-pandemi-covid19.html diakses tanggal 6 Mei 2021.

KSEI News. 2020. Komitmen KSEI dalam Pengembangan Infrastruktur Digital Pasar Modal. Jakarta: PT Kustodian Sentral Efek Indonesia.

Surat Keputusan Direksi PT Bursa Efek Indonesia Nomor Kep-00071/BEI/11-2013 Tentang Perubahan Satuan Perdagangan dan Fraksi Harga. 


\title{
OPTIMALISASI KETRAMPILAN BERTANYA UNTUK MENINGKATKAN PARTISIPASI PESERTA DIDIK DALAM PEMBELAJARAN DARING
}

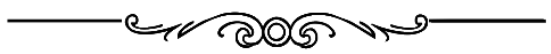

\author{
Baskoro Nugroho Putro, M.Pd. ${ }^{3}$
}

Universitas Sebelas Maret

"Proses interaksi sosial yang dilakukan oleh manusia seharihari tidak dapat lepas dari keterlibatan pertanyaan."

\section{Belajar Daring}

ntegrasi proses belajar dengan sistem daring diharapkan
untuk membantu perkembangan lingkungan belajar modern dan menyediakan kesempatan belajar yang lebih baik (Rodrigues et al., 2019). Penggunaan platform daring yang mengakomodir proses interaksi belajar secara virtual seperti zoom, webex, dan google meet membantu manusia untuk dapat berkomunikasi meskipun berada di tempat yang berbeda. Belajar daring memberi kemudahan bagi peserta didik untuk menjalani proses pembelajaran. Peserta didik tidak perlu hadir secara fisik untuk melakukan tatap

3Penulis lahir di Malang, 28 Juni 1989, penulis mengajar di prodi S1 Pendidikan Jasmani, Kesehatan dan Rekreasi Fakultas Keolahragaan Universitas Sebelas Maret. Pendidikan yang dijalani oleh penulis adalah menyelesaikan gelar Sarjana Pendidikan di Program Studi S1 Pendidikan Jasmani dan Kesehatan Universitas Negeri malang (2011), gelar Magister Pendidikan di Progam Studi S2 Pendidikan Olahraga Universitas Negeri Surabaya (2014) dan sedang menjalani Studi Doktoral di Program Studi S3 Ilmu Keolahragaan Universitas Sebelas Maret. 
muka dengan pendidik. Jauhnya jarak peserta didik dengan penyelenggara pendidikan dapat diatasi dengan sistem belajar daring. Suasana dan strategi belajar memiliki peranan penting dalam keberhasilan pembelajaran daring (Arafat et al., 2019). Belajar daring merupakan belajar yang multi proses, selain proses belajar itu sendiri di dalamnya terdapat proses penggunaan teknologi informasi dan proses pengembangan media pembelajaran berbasis digital. Tidak dapat dipungkiri bahwa penggunaan teknologi informasi tertentu dan media belajar digital mempengaruhi proses belajar daring. Hanya saja, pendidik tetap memiliki peran mutlak tentang bagaimana pembelajaran dilaksanakan. Keberhasilan pembelajaran daring ditentukan dari manajemen pembelajaran daripada kecanggihan teknologi yang digunakan (Cuku et al., 2010).

\section{Ketrampilan Bertanya}

Bertanya merupakan kegiatan yang sering dilakukan oleh manusia. Proses interaksi sosial yang dilakukan oleh manusia sehari-hari tidak dapat lepas dari keterlibatan pertanyaan. Secara sederhana bertanya digunakan untuk memuaskan rasa ingin tahu akan sesuatu. Lebih jauh lagi, bertanya merupakan proses berpikir kritis, kreatif dan usaha untuk memecahkan masalah (Chin \& Osborne, 2008). Bertanya tidak hanya ada pada interaksi sosial non-ilmiah, tetapi juga terdapat di dalam proses pembelajaran yang merupakan interaksi ilmiah antara pendidik dengan peserta didik. Sudah sewajarnya apabila proses pembelajaran harus mengarah pada pencapaian kompetensi peserta didik, oleh karena itu pertanyaan yang diberikan oleh pendidik harus mengarah pada peningkatan pemahaman materi ajar peserta didik yang berujung pada tercapainya kompetensi yang diharapkan. Bertanya merupakan bentuk sederhana dari evaluasi. Evaluasi dapat memberikan banyak 
perspektif terkait dengan hubungan sebab akibat (Levin \& McEwan, 2003). Melalui pertanyaan pendidik dapat mengetahui tingkat pemahaman dan bagian apa yang tidak dipahami oleh peserta didik. Pertanyaan merupakan bagian dari proses komunikasi yang memerlukan imbal balik. Melalui pertanyaan pendidik dapat memancing peserta didik untuk berpartisipasi dalam proses pembelajaran karena ada kewajiban sosial untuk memberikan jawaban sebagai imbal balik. Bertanya dalam proses pembelajaran tidak dapat dilakukan secara sembarangan. Diperlukan ketrampilan bertanya yang mumpuni bagi pendidik agar kelas memberikan respon yang positif (Lihat Tabel 1).

Tabel 1. Ketrampilan Bertanya (LPPMP, 2020)

\begin{tabular}{|l|l|l|}
\hline $\begin{array}{l}\text { N } \\
\text { o. }\end{array}$ & $\begin{array}{l}\text { Komponen } \\
\text { Ketrampilan }\end{array}$ & Deskripsi \\
\hline 1 & $\begin{array}{l}\text { Pertanyaan } \\
\text { diberikan secara } \\
\text { jelas dan singkat }\end{array}$ & $\begin{array}{l}\text { Pertanyaan dengan kalimat yang } \\
\text { panjang lebih sulit dipahami. }\end{array}$ \\
\hline 2 & $\begin{array}{l}\text { Memberikan } \\
\text { acuan peserta } \\
\text { didik untuk } \\
\text { memberikan } \\
\text { jawaban }\end{array}$ & $\begin{array}{l}\text { Acuan digunakan agar jawaban yang } \\
\text { diberikan peserta didik sesuai } \\
\text { dengan tema/materi ajar. }\end{array}$ \\
\hline 3 & $\begin{array}{l}\text { Pemusatan } \\
\text { pertanyaan }\end{array}$ & $\begin{array}{l}\text { Pertanyaan terpusat pada materi } \\
\text { yang dibahas dan tidak keluar dari } \\
\text { materi. }\end{array}$ \\
\hline 4 & $\begin{array}{l}\text { Pemindahan } \\
\text { giliran } \\
\text { menjawab }\end{array}$ & $\begin{array}{l}\text { Beri kesempatan pada peserta didik } \\
\text { lain untuk menjawab apabila ada } \\
\text { peserta didik yang terlalu sering } \\
\text { merespon pertanyaan. }\end{array}$ \\
\hline 5 & $\begin{array}{l}\text { Distribusi } \\
\text { Pertanyaan: } \\
\text { Bertanya pada } \\
\text { seluruh kelas, }\end{array}$ & $\begin{array}{l}\text { Pertanyaan ditujukan pada seluruh } \\
\text { kelas dan dilanjutkan menunjuk } \\
\text { peserta didik tertentu apabila tidak } \\
\text { respon. Jawaban dari mahasiwa yang }\end{array}$ \\
\hline
\end{tabular}




\begin{tabular}{|l|l|l|}
\hline & $\begin{array}{l}\text { bertanya pada } \\
\text { peserta didik } \\
\text { tertentu, } \\
\text { Menyebarkan } \\
\text { responsi peserta } \\
\text { didik }\end{array}$ & $\begin{array}{l}\text { ditunjuk dapat digunakan sebagai } \\
\text { bahan diskusi lebih lanjut. }\end{array}$ \\
\hline 6 & $\begin{array}{l}\text { Pemberian } \\
\text { waktu berpikir }\end{array}$ & $\begin{array}{l}\text { Beri waktu yang cukup bagi peserta } \\
\text { didik untuk menyusun jawaban. }\end{array}$ \\
\hline 7 & $\begin{array}{l}\text { Menuntut } \\
\text { peserta didik }\end{array}$ & $\begin{array}{l}\text { Memberikan pertanyaan dengan cara } \\
\text { lain agar peserta didik tidak bosan, } \\
\text { menyederhanakan pertanyaan bagi } \\
\text { peserta didik yang termasuk dalam } \\
\text { kategori "kurang", dan meminta } \\
\text { peserta didik mengulangi penjelasan } \\
\text { untuk meningkatkan pemahaman. }\end{array}$ \\
\hline 8 & $\begin{array}{l}\text { Urutan } \\
\text { pertanyaan }\end{array}$ & $\begin{array}{l}\text { Pertanyaan diberikan secara } \\
\text { berjenjang mulai dari yang sederhana } \\
\text { hingga kompleks. }\end{array}$ \\
\hline 9 & $\begin{array}{l}\text { Pertanyaan } \\
\text { digunakan } \\
\text { sebagai } \\
\text { analisa } \\
\text { pemahaman } \\
\text { peserta didik }\end{array}$ & $\begin{array}{l}\text { alat } \\
\text { Jawaban peserta didik harus relevan } \\
\text { klarifikasi, alasan, atau contoh. }\end{array}$ \\
\hline
\end{tabular}

\section{Aplikasi “Bertanya” dalam Proses Pembelajaran Daring}

Keterlibatan dari peserta didik sebagai bentuk interaksi sosial dan perkembangan dari peserta didik yang merujuk pada terjadinya proses merupakan bukti terlaksananya pendidikan (Ogden, 2005). Melalui pemberian pertanyaan yang tepat peserta didik dapat terlibat aktif dalam proses pembelajaran daring, meskipun proses komunikasi terjadi secara virtual. Pengunaan ketrampilan bertanya tetap mengacu pada komponen ketrampilan bertanya yang telah 
dijelaskan sebelumnya. Aplikasi pemberian pertanyaan dapat dilihat pada kerangka di bawah ini:
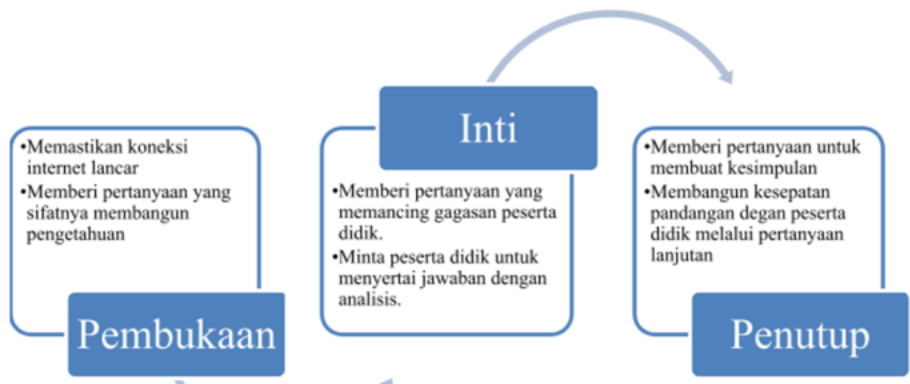

Bagan 1. Kerangka Penggunaan Ketrampilan Bertanya

Setiap kali memberikan pertanyaan dan mendapatkan respon dari peserta didik, pendidik harus kreatif agar proses komunikasi dapat berjalan secara dinamis. Terdapat langkah-langkah yang dapat digunakan sebagai acuan untuk memberi pertanyaan. Langkah-langkah tersebut adalah (Fusco, 2012):

1. Merencanakan pertanyaan yang diberikan.

2. Memberikan pertanyaan.

3. Memberi waktu peserta didik untuk berpikir.

4. Mendengarkan jawaban peserta didik.

5. Pendidik menilai jawaban peserta didik.

6. Memberi waktu peserta didik untuk memahami penilaian.

7. Pertanyaan lanjuta.

8. Kembali ke langkah pertama.

Pemberian pertanyaan yang terstruktur dan jelas tujuannya akan mempermudah pendidik untuk mengevaluasi tingkat pemahaman peserta didik. Memberi perhatian pada tingkat kesulitan pertanyaan memberikan 
waktu bagi peserta didik untuk beradaptasi dengan tuntutan pertanyaan yang semakin sulit. Pada akhirnya dengan bertanya maka pendidik secara langsung memberikan tanggung jawab peserta didik untuk terlibat aktif dalam pembelajaran dan mendorong peserta didik untuk melakukan analisa untuk memperoleh jawaban yang sesuai. Efek positif lain yang dapat diperoleh adalah melalui keterlibatan aktif dan gagasan yang diberikan, peserta didik dapat memahami materi dengan lebih mudah karena logika yang digunakan sesuai dengan pemikiran peserta didik. 


\section{Daftar Pustaka}

Arafat, S., Aljohani, N., Abbasi, R., Hussain, A., \& Lytras, M. (2019). Connections between e-learning, web science, cognitive computation and social sensing, and their relevance to learning analytics: A preliminary study. Computers in Human Behavior, 92, 478-486.

Chin, C., \& Osborne, J. (2008). Students' questions: a potential resource for teaching and learning science. Studies in Science Education, 44(1).

Cuku, M., Alfifrevic, N., Granic, A., \& Garaca, Z. (2010). Computers \& Education e-Learning process management and the e-learning performance: Results of a European empirical study. Computers \& Education, 55 , 554-565. https://doi.org/10.1016/j.compedu.2010.02.017

Fusco, E. (2012). Effective Questioning in the Classroom. In Australasian Journal of Special Education (Vol. 14, Issue 1). Teacher College Press. https://doi.org/10.1017/s1030011200022314

Levin, H. M., \& McEwan, P. J. (2003). Cost-Effectiveness Analysis as an Evaluation Tool. In Daniel L. Stufflebeam, Thomas Kellaghan, \& Lori A. Wingate (Eds.), International Handbook of Educational Evaluation (9th ed., pp. 125-148). Kluwer Academic Publishers. https://doi.org/10.1007/978-94-0100309-4

LPPMP. (2020). Modul PEKERTI AA Dosen Universitas Sebelas Maret (3rd ed.). UNS Press.

Ogden, R. M. (2005). Psychology and Educaton. Taylor \& Francis e-Library.

Rodrigues, H., Almeida, F., Figueiredo, V., \& Lopes, S. L. (2019). Tracking e-learning through published papers: A systematic review. Computers and Education, 136(December 2018), 87-98. https://doi.org/10.1016/j.compedu.2019.03.007 


\section{EFEKTIFITAS PENGGUNAAN APLIKASI BELAJAR TIDAK BERBAYAR DALAM PROSES PEMBELAJARAN DARING PADA MATA KULIAH ASUHAN KEBIDANAN KEHAMILAN}

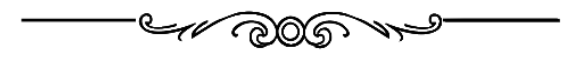

Netty Herawaty Purba, SST., M.Keb 4

\section{Program Studi Kebidanan Program Sarjana, STIKes} Awal Bros Batam

“Untuk menghadiri kelas online, dosen dan mahasiswa membutuhkan tingkat kemahiran teknologi tertentu termasuk kemampuan untuk berhasil masuk, berpartisipasi dalam kelas, mengirimkan pekerjaan, dan berkomunikasi dengan guru dan teman sekelas."

Pandemi corona virus (COVID 19) telah menjadi di indonesia, dengan sebagian besar institusi mengubah pembelajaran kelas tatap muka dan beralih ke pemebelajaran online/ daring. Pandemi ini juga mengancam untuk mengubah hampir setiap aspek kegiatan kampus secara signifikan, dari penerimaan dan pendaftaran dan kegiatan lain di perguruan tinggi. Ketika perguruan

4Netty Herawaty Purba, SST., M.Keb lahir pada tanggal 21 September 1986 di Desa Sei Kopas. Penulis Menyelesaikan pendidikan Pascasarjana Kebidanan di Universitas Padjajaran Bandung Tahun 2017. Penulis merupakan dosen kebidanan sejak tahun 2009, dan saat ini menjadi dosen prodi Kebidanan di STIKesAwal Bros Batam. Penulis bertempat tinggal di Perumahan Bida Asri I Blok B1 No.17 Batam Center, Kota Batam Kepulauan Riau. 
tinggi pindah ke kelas online untuk pengajaran, kekhawatiran tambahan muncul tentang kualitas pengajaran pendidikan yang dapat diberikan dari jarak jauh. Studi sebelumnya telah memperingatkan bahwa kinerja mahamahasiswa, terutama bagi mahasiswa yang sudah berjuang secara akademis, dapat sangat menderita dalam kursus online. Penelitian lain menemukan bahwa hingga 20\% mahasiswa memiliki masalah dalam mengakses teknologi yang efektif termasuk laptop yang berfungsi dan internet berkecepatan tinggi yang andal. Pergeseran ke kursus online juga telah mendorong banyak perguruan tinggi untuk mempertimbangkan kembali sistem penilaian untuk mencoba dan mengakomodasi dan mendukung mahasiswa dalam masa transisi.

Pengalaman baru dalam pembelajaran daring pada masa pandemi covid-19 memberikan tantangan baru baik bagi pendidik maupun peserta didik. Untuk menghadiri kelas online, dosen dan mahasiswa membutuhkan tingkat kemahiran teknologi tertentu termasuk kemampuan untuk berhasil masuk, berpartisipasi dalam kelas, mengirimkan pekerjaan, dan berkomunikasi dengan guru dan teman sekelas. Semua pendidik mendekati paradigma baru ini dengan berbagai tingkat antusiasme dan perhatian. Penting untuk mempertimbangkan pro dan kontra dari pembelajaran online sehingga dosen dapat lebih siap untuk menghadapi tantangan bekerja di lingkungan baru ini serta merangkul peluang baru yang ditawarkan.

Salah satu mata kuliah terdampak adalah mata Kuliah Asuhan kebidanan kehamilan yang mempelajari tentang asuhan kebidanan pada kehamilan dengan tujuan memberikan kemampuan kepada mahasiswa untuk dapat melaksanakan asuhan yang akan digunakan dalam praktik kebidanan yang berhubungan dengan kehamilan yang 
sesuai kompetensi profesi bidan. Selama masa pandemi ini, metode pembelajaran untuk mata kuliah asuhan kebidanan kehamilan mau tidak mau harus menggunakan metode online, agar proses belajar mengajar terus berjalan. Beberapa aplikasi yang digunakan pada pembelajaran ini yaitu edmodoo, kahoot, dan zoom. Namun dari semua aplikasi yang disebutkan diatas, masing masing mempunyai kekurangan dan kelebihan.

Edmodo merupakan platform microblogging pribadi yang dikembangkan untuk guru dan siswa, dengan mengutamakan privasi siswa. Edmodo merupakan aplikasi non berbayar alias gratis, sehingga hal ini memiliki keuntungan yang besar dari segi harga, namun walaupun gratis aplikasi ini sangat direkomendasikan karena mempunyai tampilan yang menarik, dan skala besar. Penggunaan KAHOOT sebagai salah satu media pembelajaran akan menjadi pilihan utama guru dalam mengajar, dengan menggunakan KAHOOT guru dapat menciptakan suasana belajar mengajar yang aktif dan menyenangkan. Di setiap akhir proses pembelajaran, setiap pendidik melakukan evaluasi pembelajaran untuk mengukur sejauh mana kemampuan siswa dalam memahami apa yang sudah diterangkan dengan berbagai macam cara, bisa dengan memberi kuis, presentasi secara berkelompok, test tertulis dan juga menggunakan media kahoot yaitu dengan cara memasukkan soal pilihan ganda ke aplikasi kahoot yang memang menggunakan fasilitas internet agar handphone siswa bisa terkoneksi langsung untuk menjawab kuis yang disajikan oleh pendidik melalui media kahoot tersebut (Afilisia, 2019).

Sementara untuk membantu interaksi pembelajaran dengan komunikasi secara langsung dosen menggunakan aplikasi zoom. Dimana pada saat masa pandemi ini dosen 
sebagai pengguna akses utama memiliki keberuntungan karena aplikasi ini masih diberikan secara gratis, tetapi pada dasarnya aplikasi ini adalah berbayar. Zoom adalah salah satu aplikasi cloud meeting multi platform yang dapat dimanfaatkan untuk bekerja dari rumah selama anjuran work from home (WFH) dari pemerintah diberlakukan. Salah satu keunggulan Zoom yaitu mendukung hingga 1.000 partisipan. Artinya, konferensi video atau video call bisa dilakukan bersama 1.000 orang sekaligus. Zoom juga menawarkan paket itu tetapi dengan keterbatasan, macam partisipan maksimal 100 orang, untuk group meeting maksimal 40 menit, dan hal-hal yang dibatasi lainnya. Berdasarkan pengalaman selama pemebelajran online pada mata kuliah asuhan kebidanan kehamilan dapat dilakukan evaluasi terkait kelebihan dan kekurangan dengan metode pembelajaran online.

\section{Dapat dilakukan dimana saja.}

Keuntungan utama dari pembelajaran online asinkron adalah memungkinkan siswa untuk berpartisipasi dalam situasi pembelajaran yang berkualitas tinggi ketika jarak dan jadwal membuat pembelajaran di lapangan menjadi sulit. Siswa dapat berpartisipasi dalam kelas-kelas dari mana saja di dunia asalkan mereka memiliki komputer dan koneksi internet.

\section{Kapan saja}

Kelas online dapat diakses 24 jam sehari, tujuh hari seminggu. Efisiensi waktu adalah kekuatan lain yang ada pada salah satu format pembelajaran online.

\section{Sinergi}

Pembelajaran kelas online memungkinkan interaksi yang dinamis antara dosen dan mahasiswa dan di antara mahasiswa itu sendiri. 


\section{Dialog Berkualitas}

Di dalam struktur diskusi, mahasiswa dapat merefleksikan komentar dari orang lain sebelum menanggapi atau pindah ke item berikutnya.

\section{Pemanfaatan Sumber Daya}

Siswa memiliki akses ke sumber daya dan materi yang mungkin secara fisik terletak di mana saja di dunia.

\section{Pengajaran Kreatif}

Pembelajaran orang dewasa (pedagogi) mendukung penggunaan lingkungan belajar interaktif sebagai kontribusi untuk pengarahan diri sendiri dan pemikiran kritis.

\section{Kekurangan Pembelajaran Online pada mata kuliah Asuhan Kebidanan Kehamilan}

Sementara program online memiliki kekuatan yang signifikan dan menawarkan akses yang belum pernah terjadi sebelumnya kepada pendidikan berkualitas, namun ada kelemahan yang melekat dalam penggunaan media ini yang dapat menimbulkan potensi ancaman bagi keberhasilan program online. Masalah-masalah ini terbagi atas:

\section{Teknologi}

a. Kesetaraan dan Aksesibilitas ke Teknologi

Kurangnya akses apakah karena alasan ekonomi atau logistik akan menjadi pengecualian mahassiswa yang memenuhi syarat dari pembelajaran. Sejauh menyangkut aksesibilitas Internet, itu tidak universal, dan di beberapa wilayah kepulauan riau, dengan kondisi sebagian besar merupakan kepulauan akses.

b. Keterbatasan Teknologi 
Server yang menjadi tuan rumah program dapat crash dan memotong semua peserta dari kelas; seorang peserta dapat mengakses kelas melalui komputer jaringan yang bisa turun; PC individu dapat memiliki banyak masalah yang dapat membatasi akses siswa; akhirnya, koneksi Internet bisa gagal, atau lembaga yang menampung koneksi bisa macet dengan pengguna dan memperlambat, atau gagal semuanya.

\section{Mahasiswa}

Pendidikan online memberi mahasiswa kendali atas pengalaman belajar mereka, dan memungkinkan fleksibilitas jadwal belajar bagi mahasiswa modern; Namun, ini menempatkan tanggung jawab yang lebih besar pada mahasiswa untuk memotivasi diri dan mengatur manajemen waktu dengan baik.

\section{Dosen (Fasilitator)}

a. Kualitas Belajar

Instruksi tatap muka yang sukses tidak selalu diterjemahkan menjadi instruksi online yang sukses. Jika dosen tidak terlatih dengan baik dalam penyampaian dan metodologi online, keberhasilan program online akan sulit.

\section{Lingkungan Online}

a. Tingkat Sinergi

Pembelajaran online memiliki potensi paling menjanjikan dalam sinergi tinggi yang diwakili oleh dialog aktif di antara para peserta, salah satu sumber pembelajaran paling penting di Kelas Virtual.

b. Apa Yang Seharusnya Tidak Diajarkan Online 
Antusiasme untuk program pembelajaran online yang sedang dilakukan baru-baru ini, penting untuk mengenali bahwa beberapa materi/topik pada mata kuliah asuhan kebidanna kehamilan tidak dapat diajarkan secara online karena media elektronik dalam keadaan perkembangan saat ini tidak memungkinkan metode terbaik dalam pengajaran.

\section{Kurikulum}

Kurikulum program online apa pun harus dipertimbangkan dan dikembangkan dengan hati-hati agar berhasil. Situasi yang memaksa saat ini harus menggunakan metode pembelajaran online untuk mengembangkan program pendidikan jarak jauh, pentingnya kurikulum dan kebutuhan bagi para mahasiswa yang memenuhi syarat untuk mengembangkannya diabaikan. 


\section{Daftar Pustaka}

Aflisia. N,. Karolina. A,. Yanuarti. E. 2020. "Pemanfaatan Aplikasi Kahoot untuk Meningkatkan Penguasaan Unsur Bahasa Arab". Prosiding Bahasa Arab, 1(1):117. 


\section{MENUMBUHKEMBANGKAN \\ KEPERCAYAAN DIRI PESERTA DIDIK \\ DALAM PRAKTIK BERPIDATO DI ERA \\ PEMBELAJARAN DARING

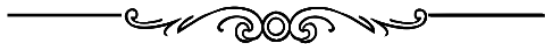

Nurul Nitasari, M. Pd. 5

MTs. N 1 Kudus

"Pembelajaran daring tidak menghalangi pendidik untuk dapat menumbuhkembangkan kepercayaan diri dan memotivasi para peserta didik."

Salah satu indikator pencapaian kompetensi dalam mata pelajaran Bahasa Indonesia kelas IX semester gasal adalah menyajikan pidato persuasif secara menarik. Hal tersebut mengharuskan pendidik dan peserta didik untuk mempersiapkan diri dalam memenuhi capaian indikator tersebut walaupun dalam era pembelajaran daring. Berpidato merupakan salah satu keterampilan yang sering digunakan di masyarakat. Oleh karena itu, diperlukan suatu kepercayaan diri sehingga seseorang dapat tampil dengan maksimal dan memukau di depan banyak orang. Dengan demikian, diperlukan peran seorang pendidik untuk

5Penulis lahir di Kudus, 25 Mei 1988, penulis merupakan Pendidik Bahasa Indonesia di MTs.N 1 Kudus. Penulis menyelesaikan gelar Sarjana Pendidikan di Universitas Negeri Semarang (2010), demikian pula gelar Magister Pendidikan diselesaikan di Universitas Negeri Semarang (2014). Penulis telah mengabdi di dunia pendidikan selama 11 tahun. 
menumbuhkan kepercayaan diri siswa sebagai bekal dalam menghadapi masa yang akan datang.

Pendidik dan peserta didik dituntut untuk melaksanakan pembelajaran praktik berpidato secara daring. Jadi, diperlukan suatu platform seperti google classroom atau zoom meeting dan sejenisnya sebagai wadah untuk penyampaian materi dan penilaiannya. Adapun teknis pelaksanaannya adalah sebagai berikut. Pertama, sebelum melakukan penilaian terhadap peserta didik, pendidik harus menjelaskan materi mengenai apa itu pidato, jenis-jenis pidato, bagaimana menyusun teks pidato, bagaimana berpidato dengan baik, dan lain sebagainya melalui platform zoom meeting dengan presentasi power point melalui share materi. Setelah itu, antara pendidik dan peserta didik dapat melakukan tanya jawab dan diskusi terhadap materi yang telah dipaparkan sehingga peserta didik akan semakin mengerti dan menguasai teori tentang berpidato.

Kedua, tahap menyusun pidato. Sebelum menyusun pidato, peserta didik dapat menentukan tema. Tema yang dipilih merupakan tema yang sudah disepakati antara pendidik dan peserta didik. Setelah itu, peserta didik dapat menyusun kerangka pidato. Kerangka pidato yang disusun harus relevan dengan tema yang sudah dipilih. Terakhir, menulis teks pidato dengan mengacu pada kerangka yang sudah disusun.

Ketiga, tahap praktik berpidato. Dalam tahapan ini, tentunya peserta didik sudah matang dalam memahami isi teks yang telah disusunnya. Pada dasarnya metode dalam berpidato ada empat jenis: (1)impromptu (spontan), (2)menghafal, (3)naskah, (4)ekstemporan (menggunakan catatan kecil). Berdasarkan pengalaman penulis yang telah mengajar materi berpidato selama 11 tahun di sekolah, 
metode yang paling cocok untuk peserta didik tingkat SMP/MTs adalah metode menghafal.

Metode menghafal mengharuskan peserta didik untuk mempersiapkan teks dan latihan secara matang. Metode ini paling cocok digunakan ketika pembelajaran dilakukan secara daring. Bagaimana tidak, dengan lebih banyak waktu di rumah, peserta didik dapat berlatih secara maksimal bersama anggota keluarga yang lain dengan melakukan simakan dan koreksi dari teks yang telah disusun sebelumnya. Setelah hafalan dirasa lancar, peserta didik dapat berlatih di depan cermin. Dengan begitu, gestur, mimik, dan vokal dapat dikoreksi secara langsung oleh peserta didik. Peserta didik juga dapat melihat dan meniru model para orator yang sedang berpidato di depan publik dari youtube, sehingga mereka dapat melihat gaya seorang orator ulung.

Peserta didik dapat mengirimkan tugas berpidato melalui rekaman video yang dapat dikirim melalui google classroom sesuai dengan tenggat waktu yang telah diberikan oleh pendidik Bahasa Indonesia. Dengan diwadahi oleh platform tersebut, pendidik dapat memberikan komentar dan saran terkait dengan penampilan peserta didik. Pendidik dapat memberikan kesempatan remidi bagi peserta didik yang penampilannya masih kurang dan nilai masih di bawah kriteria ketuntasan minimal. Sebaliknya, pendidik dapat memberikan materi dan tugas pengayaan bagi peserta didik yang nilainya sudah di atas kriteria ketuntasan minimal.

Setelah semua rekaman video terkumpul, pendidik dapat membagikan rekaman video tersebut kepada para peserta didik melalui google drive sehingga peserta didik dapat mengunduh dan memutar video milik temantemannya untuk koreksi dan menumbuhkan kepercayaan 
diri. Selain itu, mereka dapat mencontoh penampilan terbaik dari teman-temannya. Pembelajaran daring tidak menghalangi pendidik untuk dapat menumbuhkembangkan kepercayaan diri dan memotivasi para peserta didik. Bahkan, peserta didik dapat memanfaatkan peran orangtua dan teknologi yang ada untuk lebih banyak belajar serta menggali potensi yang ada dalam diri mereka. Akhirnya, kepercayaan diri pun dapat terbentuk dengan sendirinya. 


\section{INOVASI PEMBELAJARAN DARING MELALUI PEMANFAATAN HASIL PENELITIAN}

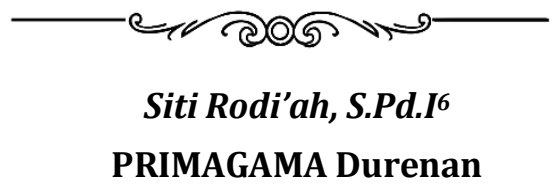

"Kunci dari keefektifan pembelajaran daring adalah pemilihan strategi pembelajaran yang inovatif."

$\mathrm{K}$ ebijakan pemerintah tentang sistem pendidikan di masa pandemi covid-19 adalah pembelajaran diarahkan pada sistem online atau daring. Kita mengenal dengan sebutan pembelajaran jarak jauh. Guru dan siswa tidak berinteraksi secara langsung saat kegiatan belajar mengajar (KBM). Tetapi, dialihkan pada interaksi secara virtual yaitu melalui penggunaan Teknologi Informasi dan Komunikasi (TIK). Hal ini akan memberikan rasa aman bagi guru dan siswa dari bahaya penularan virus covid-19. Selain itu, penggunaan Teknologi Informasi dan Komunikasi (TIK) dapat meningkatkan motivasi belajar siswa (Jung \& Zan, 2020:3). Sehingga, pembelajaran di masa pandemi covid-19 ini akan tetap berlangsung secara kondusif dengan berbantu Tekonologi Informasi dan Komunikasi (TIK).

6Penulis lahir di Tulungagung, 18 Juni 1991, penulis merupakan tentor Matematika jenjang SMP dan SD di Primagama Durenan, penulis menyelesaikan gelar Sarjana Tadris Matematika di IAIN Tulungagung (2014), penulis menyelesaikan studi Magister Pendidikan Guru Madrasah Guru Ibtidaiyah (PGMI) di IAIN Tulungagung (2020). 
Peran guru pada masa pandemi covid-19 sangat essensial yaitu memberikan inovasi pembelajaran terhadap peserta didik agar lebih termotivasi untuk mengikuti Kegiatan Belajar Mengajar (KBM) secara daring (Yahya, dkk.,2020:140). Tetapi, kenyataan di lapangan ada berbagai hambatan bagi guru dalam melaksanakan kegiatan pembelajaran secara daring. Hal ini dikarenakan adanya transformasi sistem pembelajaran dari konvensional ke arah digital. Sehingga guru dituntut untuk adaptasi pada sistem baru yaitu pemberdayaan teknologi sebagai sarana maupun media pembelajaran daring. Adaptasi ini menimbulkan masalah yang menghambat guru untuk berinovasi dalam melaksanakan Kegiatan Belajar Mengajar (KBM) secara daring. Dimana pembelajaran daring ini terkesan monoton yang mengakibatkan motivasi belajar peserta didik menjadi rendah.

Berbagai hambatan pun sudah tidak dapat dielakkan oleh guru dalam menciptakan pembelajaran daring yang inovatif. Seperti guru kurang terampil dalam mengoperasikan teknologi pada kegiatan pembelajaran daring, rendahnya pengetahuan guru dalam menentukan pendekatan pembelajaran berbasis digital serta rendahnya kompetensi guru dalam menciptakan media pembelajaran berbasis digital. Dimana hambatan-hambatan tersebut bermuara pada pembelajaran daring yang monoton dan kering akan inovasi.

Temuan di lapangan mengindikasikan bahwa pembelajaran daring diwarnai dengan pemberian tugas dari guru kepada siswa. Dimana tugas tersebut hanya berkutat pada pengerjaan LKS maupun buku siswa. Hal ini menyebabkan motivasi belajar peserta didik menjadi rendah. Yaitu ditandai oleh sikap peserta didik yang enggan mengerjakan tugas sekolah. Pasalnya, pada masa pandemi 
covid-19 peserta didik lebih dekat dengan smartphone yang menyediakan berbagai fitur-fitur menarik. Seperti, game, media sosial, youtube serta aplikasi lainnya. Game, media sosial, dan gangguan lainnya bersaing untuk mendapat perhatian siswa kecuali mereka yang sangat termotivasi dan memfokuskan pada tugas sekolah (Jill, dkk.,2020:5). Tentu, kelompok peserta didik yang memiliki motivasi belajar tinggi sangat sedikit pada suatu kelas klasikal. Kompetensi Dasar (KD) yang harus dicapai oleh peserta didik secara kolaboratif pun tidak akan menunjukkan hasil rata-rata yang baik.

Berdasarkan paparan di atas, kunci dari keefektifan pembelajaran daring adalah pemilihan strategi pembelajaran yang inovatif. Karena strategi yang dilaksanakan secara efektif berdampak pada proses pembelajaran yang baik dan mencapai hasil optimal dengan suasana yang menyenangkan (Surya, 2015:2) Proses pembelajaran akan berlangsung dengan baik, apabila didukung oleh kompetensi dan kinerja guru yang tinggi, karena guru merupakan ujung tombak dan pelaksana terhadap pendidikan peserta didik di sekolah (Suci,Damrah, 2020:192). Dalam mendukung kompetensi dan kinerja guru, maka diperlukan usaha dari guru untuk mengembangkan pengetahuannya. Agar Kegiatan Belajar Mengajar (KBM) yang dilakukan oleh guru lebih inovatif. Hal. Ini berdampak pada suasana pembelajaran daring yang menyengkan. Sehingga hasil belajar peserta didik secara klasikal mencapai nilai optimal.

Salah satau sarana penunjang kompetensi dan kinerja guru adalah memanfaatkan hasil penelitian. Dimana, data yang diperoleh dari penelitian dapat digunakan untuk memahami maslah, memecahkan masalah, mengantisipasi masalah dan untuk membuat kemajuan (Sugiyono, 2019:8). 
Melalui hasil penelitian tersebut, guru dapat mencari solusi dari praktek pembelajaran yang monoton selama masa pandemi covid-19. Yaitu berdasarkan hambatan-hambatan yang dialami oleh guru. Baik dari segi kompetensi guru, sarana dan prasarana maupun tingkat pemahaman dan karaktersistik peserta didik. Sehingga, guru dapat menciptakan Kegiatan Belajar Mengajar (KBM) yang lebih inovatif.

Selain karya ilmiah berupa artikel, guru dapat memanfaatkan sumber rujukan lain berupa buku. Tetapi, buku lebih mengarah pada teoritis saja. Belum mengarah pada analisis maupun strategi berdasarkan fenomena yang dialami oleh guru. Hal ini memberikan kesulitan bagi guru secara praktis untuk menerapkan atau memanfaatkan teori-teori yang dipaparkan pada buku. Karena ketidaksesuaian antara teori yang dipaparkan pada buku dengan kondisi dan daya dukung yang terjadi oleh guru saat pembelajaran daring. Jika merujuk pada hasil penelitian, guru dapat memanfaatkan teori maupun strategi yang disesuaikan dengan kondisi dan daya dukung. Hal inilah yang menjadikan pertimbangan bagi penulis, bahwa hasil penelitian dapat dijadikan bahan rujukan yang up to date maupun praktis untuk kemajuan kompetensi dan kinerja guru.

Di era digital seperti sekarang ini, tentu sangat mudah bagi guru untuk mengakses hasil penelitian dari para peneliti. Banyak sekali situs di web yang mengantarkan guru untuk mengakses hasil penelitian berupa artikel secara online. Tetapi, sebaiknya guru harus cermat dalam memilih artikel penelitian. Jangan sampai artikel yang dirujuk adalah karya ilmiah abal-abalan. Hal ini akan merugikan bagi guru. Karena data penelitian yang dipaparkan tidak objektif, representatif, up to date, dan 
relevan. Tentu, guru tidak akan menemukan solusi atau ide untuk mengembangkan strategi pembelajaran daring yang lebih inovatif. Sehingga, artikel yang ditelaah pun tidak dapat dimanfaatkan untuk kemajuan kompetensi dan kinerja guru.

Salah satu situs jurnal ilmiah yang terakreditasi Nasional adalah SINTA. Melalui situs SINTA, guru dapat menemukan berbagai artikel sesuai kebutuhan. Mulai dari kebutuhan pengembangan materi pelajaran, desain media berbasis digital, strategi pembelajaran berbasis digital, analisis kesulitan belajar siswa, dan lain sebagainya. Hal ini tergantung hambatan dan kondisi guru saat melaksanakan Kegiatan Belajar Mengajar (KBM) secara daring. Yaitu berdasarkan tingkat kompetensi guru, karakteristik peserta didik, maupun sarana dan prasarana yang telah tersedia. Guru dapat memanfaatkan hasil penelitian tersebut berdasarkan daya dukung dan kondisi pembelajaran daring yang sedang dialaminya. Baik berupa teori, strategi maupun solusi yang dapat dijadikan rujukan untuk kemajuan pembelajaran daring ke arah yang lebih inovatif.

Berbagai kajian penelitian pun telah tersedia pada situs jurnal. Baik berupa studi komprehensif antara teori dengan objek penelitian, hubungan teori dengan objek penelitian dan menemukan teori baru maupun pengembangan produk pendidikan. Guru dapat memilih artikel ilmiah sesuai kebutuhan dan potensi guru dalam memanfaatkan hasil penelitian tersebut. Selain ditinjau dari kebutuhan dan kompetensi guru, tentu penyesuaian dengan masalah maupun fenomena yang terjadi adalah hal yang harus diperhatikan. Hal ini berdampak pada kesesuaian teori yang ditemukan pada artikel terhadap kenyataan yang dialami oleh guru. Sehingga, guru dapat menentukan strategi yang inovatif serta sesuai dengan karakteristik 
peserta didik maupun kondisi sarana dan prasarana yang ada.

Berdasarkan uraian di atas, diharapkan hasil penelitian dapat memberikan kontribusi pada pengembangan kompetensi dan kinerja guru. Agar pembelajaran daring lebih mengarah pada hal yang baru atau inovatif. Usaha guru sangat berpengaruh terhadap kemajuan pendidikan. Rajin membaca, menelaah, menganalisa, dan dipraktekkan langsung adalah wujud konkret dari usaha perbaikan kinerja guru. Masa pandemi ini adalah momen yang pas bagi guru untuk mengembangkan kompetensinya. Banyak waktu longgar yang dapat dimanfaatkan oleh guru untuk membuka situs jurnal dan menelaahnya. Sehingga, guru dapat menciptakan inovasi pembelajaran daring yang menyenangkan bagi peserta didik. Agar Kompetensi Dasar (KD) yang harus dicapai oleh peserta didik menunjukkan hasil yang optimal.

\section{Daftar Pustaka}

Anita, Suci., Damrah. 2020. Kinerja Guru Pendidikan Jasmani Olahraga Dan Kesehatan Di masa New Normal Covid-19. Jurnal Kesehatan Medika Saintika. Vol. 11, No. 2, DOI: http://dx.doi.org/10.30633/jkms.v1lil.859

Gandhi, Jill, dkk. 2020. The Effects of Two Mindset Interventions on Low-Income Students' Academic and Psychological Outcomes. Journal Of Research on Educationl Effectiveness. DOI: 10.1080/19345747.2019.1711272

Lee, Eun, Jung., Gao, Zan. 2020. Effects of the iPad and Mobile Application Integrated Physical Education on Children's Physical Activity and Psychosocial Beliefs. Journal Physical Education and Sport Pedagogy. DOI: 10.1080/17408989.2020.1761953 
Nopiyanto, Eko Yahya., dkk. 2020. Hambatan Guru Pendidikan Jasmani Generasi 80-an Dalam Pembelajaran Daring Di Tengah Pandemi Covid-19. Jurnal Sporta Saintika. Vol. 5. No. 2. September 2020.

Sugiyono. 2019. Metode Penelitan Pendidikan. Yogyakarta: Alfabeta

Surya, Mohamad. 2015. Strategi Kognitif dalam Pembelajaran. Bandung: Alfabeta 


\title{
OPTIMALISASI PEMAHAMAN \\ MAHASISWA MATA KULIAH EVALUASI \\ PEMBELAJARAN PENJASORKES MELALUI \\ STRATEGI PEMBELAJARAN DARING
}

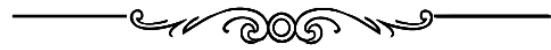

\section{Maria Andriani Barek Ladjar,S.Si., M.Pd,7 \\ Universitas Nusa Cendana-Kupang}

\begin{abstract}
"Sebagian kecil mahasiswa tidak mampu menjawab pertanyaan, dipengaruhi oleh kendala mereka untuk mengikuti pembelajaran daring dan kesulitan mereka menonton ulang hasil rekaman penjelasan materi baru”
\end{abstract}

alah satu permasalahan utama yang dialami saat
pembelajaran dilakukan secara daring yaitu, tingkat pemahaman mahasiswa menjadi kurang optimal. Dosen merupakan aktor utama yang memegang peranan dalam mengatasi permasalahan tersebut. Sebagaimana dikemukakan Raibowo, S., Nopiyanto, Y. E., \& Muna, M. K. (2020:14) menyatakan bahwa guru harus mempunyai inovasi dalam memberikan pengajaran. Maka dosen pun harus memiliki inovasi secara khusus strategi dalam melaksanakan pembelajaran daring untuk mengatasi "gagal

7Penulis lahir di Bandung, 26 Maret 1990, penulis merupakan Dosen Universitas Nusa Cendana dalam bidang ilmu Pembelajaran Olahraga dan Kesehatan, penulis menyelesaikan gelar Sarjana Ilmu Keolahragaan di Universitas Pendidikan Indonesia (2014) dan mendapatkan gelar Magister Pendidikan di Universitas Pendidikan Indonesia Program Studi Pendidikan Olahraga (2018). Riwayat Pekerjaan: 2014-2018 menjadi guru PJOK di SMP Santa Ursula Bandung, 2019-sekarang menjadi Dosen Penjaskesrek FKIP Undana Kupang. 
paham". Penulis mengindikasi terjadinya "gagal paham" yang dialami oleh mahasiswa secara khusus untuk mata kuliah Evaluasi Pembelajaran Penjasorkes selama pembelajaran daring.

Indikator yang menjadi acuan dari terjadinya "gagal paham" pada mata kuliah ini, penulis bagi menjadi 2 aspek utama, yaitu: 1) Gagal paham terhadap materi baru, 2) Gagal paham terhadap materi tambahan. Penulis memberikan tes pemahaman terhadap materi baru setelah melaksanakan pembelajaran daring selama 7 pertemuan. Kemudian penulis memberikan tes pemahaman terhadap materi tambahan setelah penulis memberikan 7 pertemuan berikutnya. Kriteria penelitian dalam tes pemahaman ini secara rinci dapat dilihat dalam Tabel 1.1 dibawah ini.

Tabel 1.1 Kriteria Penilaian Tes Pemahaman Mahasiswa

\begin{tabular}{|l|l|}
\hline Nilai & Kategori \\
\hline$<43$ & Sangat Kurang \\
\hline $43-59$ & Kurang \\
\hline $60-70$ & Cukup \\
\hline $71-84$ & Baik \\
\hline$>84$ & Sangat Baik \\
\hline
\end{tabular}

Berdasarkan Kriteria Penilaian diatas terdapat lima kategori untuk rentang nilai yang diperoleh oleh masingmasing mahasiswa, mulai dari sangat kurang sampai dengan sangat baik. Kriteria penilaian ini yang digunakan kepada kedua tes pemahaman, dan diperoleh hasil tes seperti ditunjukan pada Tabel 1.2 dibawah ini. 
Tabel 1.2 Hasil Penilaian Pemahaman Mahasiswa Terhadap Materi Baru dan Materi Tambahan

\begin{tabular}{|c|c|c|c|c|c|c|c|}
\hline \multicolumn{4}{|c|}{ Pemahaman Materi Baru } & \multicolumn{4}{|c|}{ Pemahaman Materi Tambahan } \\
\hline No & $\begin{array}{c}\text { Nama } \\
\text { Mahasisw } \\
\text { a }\end{array}$ & $\begin{array}{c}\text { Nil } \\
\text { ai }\end{array}$ & $\begin{array}{c}\text { Katego } \\
\text { ri }\end{array}$ & No & $\begin{array}{c}\text { Nama } \\
\text { Mahasisw } \\
\text { a }\end{array}$ & Nilai & Kategori \\
\hline 1 & $\begin{array}{l}\text { Yanuariu } \\
\text { s Banfatin }\end{array}$ & 10 & $\begin{array}{l}\text { Sangat } \\
\text { Kurang }\end{array}$ & 1 & $\begin{array}{l}\text { Antonius } \\
\text { Barbagio } \\
\text { Jeha }\end{array}$ & 10 & $\begin{array}{l}\text { Sangat } \\
\text { Kurang }\end{array}$ \\
\hline 2 & $\begin{array}{l}\text { Yerdin } \\
\text { Yosua } \\
\text { Maubanu }\end{array}$ & 10 & $\begin{array}{l}\text { Sangat } \\
\text { Kurang }\end{array}$ & 2 & $\begin{array}{l}\text { Jefren } \\
\text { Imanuel } \\
\text { Tino }\end{array}$ & 10 & $\begin{array}{l}\text { Sangat } \\
\text { Kurang }\end{array}$ \\
\hline 3 & $\begin{array}{l}\text { Adrianus } \\
\text { Edmonda } \\
\text { ntes } \\
\text { Marthinu } \\
\text { s }\end{array}$ & 15 & $\begin{array}{l}\text { Sangat } \\
\text { Kurang }\end{array}$ & 3 & $\begin{array}{l}\text { Ongki } \\
\text { Armanita } \\
\text { Nomleni }\end{array}$ & 10 & $\begin{array}{l}\text { Sangat } \\
\text { Kurang }\end{array}$ \\
\hline 4 & $\begin{array}{l}\text { Ongki } \\
\text { Armanita } \\
\text { Nomleni }\end{array}$ & 20 & $\begin{array}{l}\text { Sangat } \\
\text { Kurang }\end{array}$ & 4 & $\begin{array}{l}\text { Yerdin } \\
\text { Yosua } \\
\text { Maubanu }\end{array}$ & 10 & $\begin{array}{l}\text { Sangat } \\
\text { Kurang }\end{array}$ \\
\hline 5 & $\begin{array}{l}\text { Selvianus } \\
\text { Salmon } \\
\text { Lily }\end{array}$ & 20 & $\begin{array}{l}\text { Sangat } \\
\text { Kurang }\end{array}$ & 5 & $\begin{array}{l}\text { Vigelus } \\
\text { Hermoge } \\
\text { nes Lay } \\
\text { Kore }\end{array}$ & 10 & $\begin{array}{l}\text { Sangat } \\
\text { Kurang }\end{array}$ \\
\hline 6 & $\begin{array}{l}\text { Naaman } \\
\text { Bukagton } \\
\text { ung }\end{array}$ & 30 & $\begin{array}{l}\text { Sangat } \\
\text { Kurang }\end{array}$ & 6 & $\begin{array}{l}\text { Adrianus } \\
\text { Edmonda } \\
\text { ntes } \\
\text { Marthinu } \\
\text { s }\end{array}$ & 15 & $\begin{array}{l}\text { Sangat } \\
\text { Kurang }\end{array}$ \\
\hline 7 & $\begin{array}{l}\text { Yohanes } \\
\text { D B Noa }\end{array}$ & 30 & $\begin{array}{l}\text { Sangat } \\
\text { Kurang }\end{array}$ & 7 & $\begin{array}{l}\text { Libertheo } \\
\text { Babys }\end{array}$ & 15 & $\begin{array}{l}\text { SangatKur } \\
\text { ang }\end{array}$ \\
\hline 8 & $\begin{array}{l}\text { Antonius } \\
\text { Barbagio } \\
\text { Jeha }\end{array}$ & 50 & Kurang & 8 & $\begin{array}{l}\text { Selvianus } \\
\text { Salmon } \\
\text { Lily }\end{array}$ & 15 & $\begin{array}{l}\text { Sangat } \\
\text { Kurang }\end{array}$ \\
\hline 9 & $\begin{array}{l}\text { Toni } \\
\text { Yonathan } \\
\text { Sapay }\end{array}$ & 0 & Kurang & 9 & $\begin{array}{l}\text { Yanuariu } \\
\text { s Banfatin }\end{array}$ & 15 & $\begin{array}{l}\text { Sangat } \\
\text { Kurang }\end{array}$ \\
\hline 10 & $\begin{array}{l}\text { Roimelda } \\
t\end{array}$ & 55 & Kurang & 10 & $\begin{array}{l}\text { Aprianus } \\
\text { Afrien }\end{array}$ & 20 & $\begin{array}{l}\text { Sangat } \\
\text { Kurang }\end{array}$ \\
\hline
\end{tabular}




\begin{tabular}{|c|c|c|c|c|c|c|c|}
\hline \multicolumn{4}{|c|}{ Pemahaman Materi Baru } & \multicolumn{4}{|c|}{ Pemahaman Materi Tambahan } \\
\hline No & $\begin{array}{c}\text { Nama } \\
\text { Mahasisw } \\
\text { a }\end{array}$ & $\begin{array}{c}\text { Nil } \\
\text { ai }\end{array}$ & $\begin{array}{c}\text { Katego } \\
\text { ri }\end{array}$ & No & $\begin{array}{c}\text { Nama } \\
\text { Mahasisw } \\
\text { a }\end{array}$ & Nilai & Kategori \\
\hline & Tampani & & & & $\begin{array}{l}\text { Nitanel } \\
\text { Faot }\end{array}$ & & \\
\hline 11 & $\begin{array}{l}\text { Aman } \\
\text { Agung } \\
\text { Tlonaen }\end{array}$ & 60 & Cukup & 11 & $\begin{array}{l}\text { Fatri } \\
\text { Yosafrit } \\
\text { Silla }\end{array}$ & 20 & $\begin{array}{l}\text { Sangat } \\
\text { Kurang }\end{array}$ \\
\hline 12 & $\begin{array}{l}\text { Fatri } \\
\text { Yosafrit } \\
\text { Silla }\end{array}$ & 60 & Cukup & 12 & $\begin{array}{l}\text { Muhamm } \\
\text { ad Ardi }\end{array}$ & 20 & $\begin{array}{l}\text { Sangat } \\
\text { Kurang }\end{array}$ \\
\hline 13 & $\begin{array}{l}\text { Frislin } \\
\text { Paskaline } \\
\mathrm{r} \quad \text { Y. } \\
\text { Nenotek }\end{array}$ & 60 & Cukup & 13 & $\begin{array}{l}\text { Naaman } \\
\text { Bukagton } \\
\text { ung }\end{array}$ & 20 & $\begin{array}{l}\text { Sangat } \\
\text { Kurang }\end{array}$ \\
\hline 14 & $\begin{array}{l}\text { Jefren } \\
\text { Imanuel } \\
\text { Tino }\end{array}$ & 60 & Cukup & 14 & $\begin{array}{l}\text { Toni } \\
\text { Yonathan } \\
\text { Sapay }\end{array}$ & 20 & $\begin{array}{l}\text { Sangat } \\
\text { Kurang }\end{array}$ \\
\hline 15 & $\begin{array}{l}\text { Laurensi } \\
\text { us } \\
\text { Fildrenjel }\end{array}$ & 60 & Cukup & 15 & $\begin{array}{l}\text { Reymond } \\
\text { Berthi } \\
\text { Suek }\end{array}$ & 30 & $\begin{array}{l}\text { Sangat } \\
\text { Kurang }\end{array}$ \\
\hline 16 & $\begin{array}{l}\text { Mildon R. } \\
\text { Metta }\end{array}$ & 60 & Cukup & 16 & $\begin{array}{l}\text { Yuventus } \\
\text { Nahak } \\
\text { Tahu }\end{array}$ & 30 & $\begin{array}{l}\text { Sangat } \\
\text { Kurang }\end{array}$ \\
\hline 17 & $\begin{array}{l}\text { Nuruddin } \\
\text { Ramadha } \\
\text { n Mukin }\end{array}$ & 60 & Cukup & 17 & $\begin{array}{l}\text { Frislin } \\
\text { Paskaline } \\
\mathrm{r} \quad \text { Y. } \\
\text { Nenotek }\end{array}$ & 30 & $\begin{array}{l}\text { Sangat } \\
\text { Kurang }\end{array}$ \\
\hline 18 & $\begin{array}{l}\text { Petrus } \\
\text { Damianu } \\
\text { s Subang } \\
\text { Flor }\end{array}$ & 60 & Cukup & 18 & $\begin{array}{l}\text { Roberto } \\
\text { Tutpai }\end{array}$ & 35 & $\begin{array}{l}\text { Sangat } \\
\text { Kurang }\end{array}$ \\
\hline 19 & $\begin{array}{l}\text { Reymond } \\
\text { Berthi } \\
\text { Suek }\end{array}$ & 60 & Cukup & 19 & $\begin{array}{l}\text { Roimelda } \\
\mathrm{t} \\
\text { Tampani }\end{array}$ & 35 & $\begin{array}{l}\text { Sangat } \\
\text { Kurang }\end{array}$ \\
\hline 20 & $\begin{array}{l}\text { Roberto } \\
\text { Tutpai }\end{array}$ & 60 & Cukup & 20 & $\begin{array}{l}\text { Yohanes } \\
\text { D B Noa }\end{array}$ & 35 & $\begin{array}{l}\text { Sangat } \\
\text { Kurang }\end{array}$ \\
\hline 21 & Roynaldi & 60 & Cukup & 21 & Amram & 50 & Kurang \\
\hline
\end{tabular}




\begin{tabular}{|c|c|c|c|c|c|c|c|}
\hline \multicolumn{4}{|c|}{ Pemahaman Materi Baru } & \multicolumn{4}{|c|}{ Pemahaman Materi Tambahan } \\
\hline No & $\begin{array}{c}\text { Nama } \\
\text { Mahasisw } \\
\text { a }\end{array}$ & $\begin{array}{l}\mathrm{Nil} \\
\text { ai }\end{array}$ & $\begin{array}{c}\text { Katego } \\
\text { ri }\end{array}$ & No & $\begin{array}{c}\text { Nama } \\
\text { Mahasisw } \\
\text { a }\end{array}$ & Nilai & Kategori \\
\hline & $\begin{array}{l}\text { Jordi } \\
\text { Sanu }\end{array}$ & & & & $\begin{array}{l}\text { Felipus } \\
\text { Selan }\end{array}$ & & \\
\hline 22 & $\begin{array}{l}\text { Rusli } \\
\text { Lasarus } \\
\text { Nggadas }\end{array}$ & 60 & Cukup & 22 & $\begin{array}{l}\text { Nofia Ayu } \\
\text { Puspita } \\
\text { Kale }\end{array}$ & 55 & Kurang \\
\hline 23 & $\begin{array}{l}\text { Libertheo } \\
\text { Babys }\end{array}$ & 70 & Cukup & 23 & $\begin{array}{l}\text { Arnold } \\
\text { Gideon } \\
\text { Rassi }\end{array}$ & 65 & Cukup \\
\hline 24 & $\begin{array}{l}\text { Yuventus } \\
\text { Nahak } \\
\text { Tahu }\end{array}$ & 78 & Baik & 24 & $\begin{array}{l}\text { Dessy } \\
\text { Mata } \\
\text { Taga }\end{array}$ & 65 & Cukup \\
\hline 25 & $\begin{array}{l}\text { Amram } \\
\text { Felipus } \\
\text { Selan }\end{array}$ & 80 & Baik & 25 & $\begin{array}{l}\text { Mildon R. } \\
\text { Metta }\end{array}$ & 65 & Cukup \\
\hline 26 & $\begin{array}{l}\text { Aprianus } \\
\text { Afrien } \\
\text { Nitanel } \\
\text { Faot }\end{array}$ & 80 & Baik & 26 & $\begin{array}{l}\text { Nuruddin } \\
\text { Ramadha } \\
\text { n Mukin }\end{array}$ & 65 & Cukup \\
\hline 27 & $\begin{array}{l}\text { Arnold } \\
\text { Gideon } \\
\text { Rassi }\end{array}$ & 80 & Baik & 27 & $\begin{array}{l}\text { Delvita } \\
\text { Lodia } \\
\text { Bakun }\end{array}$ & 70 & Cukup \\
\hline 28 & $\begin{array}{l}\text { Delvita } \\
\text { Lodia } \\
\text { Bakun }\end{array}$ & 80 & Baik & 28 & $\begin{array}{l}\text { Aman } \\
\text { Agung } \\
\text { Tlonaen }\end{array}$ & 75 & Baik \\
\hline 29 & $\begin{array}{l}\text { Dessy } \\
\text { Mata } \\
\text { Taga }\end{array}$ & 80 & Baik & 29 & $\begin{array}{l}\text { Rusli } \\
\text { Lasarus } \\
\text { Nggadas }\end{array}$ & 75 & Baik \\
\hline 30 & $\begin{array}{l}\text { Fredrik } \\
\text { Apryanto } \\
\text { Lede }\end{array}$ & 80 & Baik & 30 & $\begin{array}{l}\text { Nur } \\
\text { Hadjra } \\
\text { Tamal }\end{array}$ & 80 & Baik \\
\hline 31 & $\begin{array}{l}\text { Muhamm } \\
\text { ad Ardi }\end{array}$ & 80 & Baik & 31 & $\begin{array}{l}\text { Petrus } \\
\text { Damianu } \\
\text { s Subang } \\
\text { Flor }\end{array}$ & 80 & Baik \\
\hline 32 & Nofia Ayu & 80 & Baik & 32 & Fredrik & 100 & Sangat \\
\hline
\end{tabular}




\begin{tabular}{|c|c|c|c|c|c|c|c|}
\hline \multicolumn{4}{|c|}{ Pemahaman Materi Baru } & \multicolumn{4}{|c|}{ Pemahaman Materi Tambahan } \\
\hline No & $\begin{array}{c}\text { Nama } \\
\text { Mahasisw } \\
\text { a }\end{array}$ & $\begin{array}{l}\mathrm{Nil} \\
\text { ai }\end{array}$ & $\begin{array}{c}\text { Katego } \\
\text { ri }\end{array}$ & No & $\begin{array}{c}\text { Nama } \\
\text { Mahasisw } \\
\text { a }\end{array}$ & Nilai & Kategori \\
\hline & $\begin{array}{l}\text { Puspita } \\
\text { Kale }\end{array}$ & & & & $\begin{array}{l}\text { Apryanto } \\
\text { Lede }\end{array}$ & & Baik \\
\hline 33 & $\begin{array}{l}\text { Nur } \\
\text { Hadjra } \\
\text { Tamal }\end{array}$ & 80 & Baik & 33 & $\begin{array}{l}\text { Laurensi } \\
\text { us } \\
\text { Fildrenjel }\end{array}$ & 100 & $\begin{array}{l}\text { Sangat } \\
\text { Baik }\end{array}$ \\
\hline 34 & $\begin{array}{l}\text { Vigelus } \\
\text { Hermoge } \\
\text { nes Lay } \\
\text { Kore }\end{array}$ & 80 & Baik & 34 & $\begin{array}{l}\text { Roynaldi } \\
\text { Jordi } \\
\text { Sanu }\end{array}$ & 100 & $\begin{array}{l}\text { Sangat } \\
\text { Baik }\end{array}$ \\
\hline
\end{tabular}

Berdasarkan Tabel 1.2 hasil tes pemahaman terhadap materi baru menunjukan dari total keseluruhan 34 mahasiswa, antara mahasiswa yang memperoleh kategori baik dan cukup hampir seimbang, dimana 11 orang dengan kategori baik dan 13 orang dengan kategori cukup. Maka sebanyak 24 orang dinyatakan memiliki pemahaman yang cukup memadai dalam menerima materi baru pada mata kuliah Evaluasi Pembelajaran Penjasorkes. Sedangkan sisanya sebanyak 10 orang memiliki pemahaman yang kurang memadai dalam menyerap materi baru dalam mata kuliah Evaluasi Pembelajaran Penjasorkes. Jika diambil prosentase tingkat pemahaman mahasiswa antara yang dapat memahami dan yang kurang maka 71\% mahasiswa cukup memahami materi baru, dan 29\% mahasiswa yang kurang memahami materi baru. Maka dapat disimpulkan mayoritas mahasiswa dapat memahami materi baru.

Penulis memberikan beberapa poin yang ikut mempengaruhi sebagian kecil mahasiswa gagal untuk memahami materi baru pada mata kuliah Evaluasi Pembelajaran Penjasorkes, yaitu: 1) Bagi sebagian kecil mahasiswa, mereka kesulitan untuk mengakses Zoom Meeting mapupun Youtube serta jaringan internet yang 
tidak stabil menyebabkan mereka mengalami kendala dalam memahami materi baru. 2) Strategi Pembelajaran daring melalui pembelajaran dua arah (dengan mengajukan tanya jawab) kepada mahasiswa saat sedang melakukan pembahasan materi baru melalui media Zoom Meeting. Melalui pertanyaan tersebut, mahasiswa berusaha untuk menemukan cara untuk mengerjakan hasil evaluasi yang benar. Konsekuensi bagi mahasiswa yang tidak berkonsentrasi saat pembahasan materi baru, maka tidak mampu menjawab pertanyaan, dan penulis akan langsung memberikan pengurangan poin pada nilai mahasiswa tersebut. Sebagian kecil mahasiswa tidak mampu menjawab pertanyaan, dipengaruhi oleh kendala mereka untuk mengikuti pembelajaran daring dan kesulitan mereka menonton ulang hasil rekaman penjelasan materi baru, dan ini yang menjadi awal kenapa hasil akhir yang diperoleh tidak maksimal sehingga hanya mampu mencapai kategori sangat kurang dan kurang. Kedua poin utama ini yang menjadi kunci dalam memberikan pemahaman kepada mahasiswa supaya mampu menerima materi baru dengan baik.

Berdasarkan Tabel 1.2 pemahaman mahasiswa terhadap materi tambahan, maka dapat diketahui bahwa sebanyak 20 orang sangat kurang memahami materi tambahan, dan sebanyak 2 orang kurang memahami, sehingga jika dijumlahkan maka total mahasiswa yang kurang mampu memahami materi tambahan sebanyak 22 orang. Sedangkan untuk mahasiswa yang cukup memahami materi tambahan sebanyak 5 orang, mahasiswa yang dapat memahami materi tambahan dengan baik sebanyak 4 orang , dan sebanyak 3 orang dapat memahami dengan sangat baik, sehingga jika dijumlahkan maka total mahasiswa yang mampu memahami materi tambahan sebanyak 12 orang. 
Jika diprosentasekan maka 65\% mahasiswa kurang mampu memahami materi tambahan, dan 35\% mahasiswa mampu memahami materi tambahan. Maka dapat disimpulkan mayoritas mahasiswa kurang mampu memahami materi tambahan dalam mata kuliah Evaluasi Pembelajaran Penjasorkes.

Penulis memberikan beberapa poin yang ikut mempengaruhi mayoritas mahasiswa kurang memahami materi tambahan pada mata kuliah Evaluasi Pembelajaran Penjasorkes, yaitu: 1) Strategi pembelajaran daring secara terbimbing dimana penulis memberikan bimbingan penuh selama pemberian materi tambahan. Adapun materi tambahannya berupa penggunaan Microsoft Excel dalam membuat rumus sehingga hasil evaluasi lebih akurat dan mampu menghemat waktu jika jumlah sampel yang dievaluasi sangat banyak. Namun, ternyata mahasiswa mengalami kesulitan untuk memahami penggunaan Microsoft Excel dalam membuat rumus. Tidak semua mahasiswa memiliki komputer atau laptop untuk bisa membuka Microsoft Excel, sehingga saat penulis melakukan Zoom Meeting melakukan praktek cara memasukan rumus, mahasiswa tidak bisa dalam waktu yang sama melakukan praktek memasukan rumus.

Penulis sudah memberikan bantuan dengan mengunggah hasil rekaman ke media Youtube sehingga mahasiswa yang tidak bisa melakukan praktek secara langsung saat Zoom Meeting mampu menonton ulang rekaman dan mencoba meminjam laptop teman (mengupayakan cara supaya dapat mengakses Microsoft Excel) untuk melakukan praktek sendiri. Namun, kenyataannya mahasiswa hanya sebagian kecil saja yang memiliki kesadaran untuk berusaha, terlepas dari kesulitan mengakses internet. 
2) Strategi Pembelajaran daring dengan tutor sebaya. Penulis juga menggunakan tutor sebaya saat melaksanakan Zoom Meeting untuk membantu mahasiswa mampu memahami materi tambahan. Namun, ini semua kembali lagi kepada kesadaran mahasiswa tersebut mencoba untuk praktek langsung mengakses Microsoft Excel sehingga memiliki gambaran tentang rumus yang dijelaskan oleh tutor sebaya.

Kesimpulan yang diperoleh upaya untuk mengoptimalkan pemahaman mahasiswa selama pembelajaran daring memiliki kendala dan hambatan tersendiri. Namun, dengan strategi pembelajaran daring; 1) pembelajaran dua arah (dengan mengajukan tanya jawab), 2) pembelajaran secara terbimbing, dan 3) tutor sebaya dapat membantu meningkatkan pemahaman mahasiswa dalam menerima materi baru dan materi tambahan. 


\section{Daftar Pustaka}

Raibowo, S., Nopiyanto, Y. E., \& Muna, M. K. (2020). Pemahaman guru PJOK tentang standar kompetensi profesional. Journal of Sport Education (JOPE), 2(1), 10-15. 


\title{
EDUKASI DINI PENDIDIKAN MODERASI BERAGAMA PADA KEGIATAN PONDOK RAMADHAN DI TINGKAT MADRASAH
}

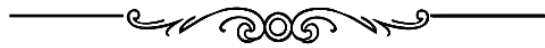 \\ Emy Putri Alfiyah, S.Th.I8 \\ MIN 3 Tulungagung
}

"Dengan tingkat keberagaman yang majemuk, edukasi mengenai keberagaman di Indonesia memang menjadi fundament ketika dihadapkan dengan situasi Indonesia."

Sudah kian tahun Negara Kesatuan Republik Indonesia telah merdeka dari penjajahan. Lika dan liku para pejuang kemerdekaan telah membuahkan hasil, yaitu sebuah ideologi. Ideologi negara Indonesia tersebut disusun dan di-rembug-kan berkali-kali untuk disesuaikan dengan kondisi bangsa Indonesia yang beragam. Bukan disusun dengan sembarang ataupun sewenang-wenang, namun digubah dan diubah agar sesuai dengan norma dan nilai pada masyarakat sekitar.

Ideologi bangsa Indonesia yang kita kenal dengan Pancasila, berisi lima sila yaitu yang berbunyi;

1. Ketuhanan Yang Maha Esa

2. Kemanusiaan yang Adil dan Beradab

3. Persatuan Indonesia

8Penulis lahir di Kediri, 07 Pebruari 1990. Penulis adalah alumni IAIN Kediri S1 Perbandingan Agama Tahun 2013. Pada tahun 2019 menjadi pengajar di lingkungan Kementerian Agama Tulungagung, tepatnya di MIN 3 Tulungagung. 
4. Kerakyatan yang Dipimpin oleh Hikmat Kebijaksanaan dalam Permusyawaratan/ Perwakilan

5. Keadilan Sosial bagi seluruh Rakyat Indonesia.

Kelima sila yang tertuang dalam Pancasila serta tercantum pada alinea ke-4 dalam Pembukaan UndangUndang Dasar 1945 telah mewakili kesatuan dan persatuan bangsa Indonesia. Terbentuknya Pancasila juga telah mengalami perubahan isi dan urutan yang berlangsung dalam beberapa tahap selama masa perumusan Pancasila. Para pejuang kemerdekaan juga tidak serta merta memutuskan isi lima Pancasila begitu saja tanpa pertimbangan. Rumusan sila lima tersebut bahkan menjadi bahasan panjang di masanya dengan mengedepankan kepentingan seluruh rakyat Indonesia.

Namun, sepanjang sejarah setelah Indonesia merdeka masih ditemui beberapa kelompok kepentingan yang berupaya membubrah ideologi Pancasila. Kelompokkelompok tersebut menginginkan perubahan pada tatanan pemerintahan di Indonesia. Alih-alih membawa agama dan atas nama Tuhan ikut disertakan. Adapun yang mengumumkan diri sebagai keturunan atau titisan dari kerajaan dengan membawa titah beragam. Yang pada intinya, semua itu adalah untuk mengubah ideologi Pancasila. Haruskah ideologi yang disusun apik para pejuang kemerdekaan dikorbankan hanya karena kepentingan suatu kelompok yang meronta-ronta menginginkan sebuah kekuasaan, atau bahkan mungkin mencari ketenaran dan perhatian publik.

Kondisi ini menggambarkan bahwa sebagian masyarakat masih awam pengetahuan tentang sejarah panjang perjalanan ideologi Pancasila. Sehingga mudah bagi pemangku kelompok kepentingan melancarkan aksinya 
untuk mencari dukungan. Maka tak heran informasi yang didapat itu ditelan dengan mentah-mentah apalagi di masa digitalisasi. Segala informasi mudah didapat dan diakses, akan tetapi harus tetap dipilih agar tidak menimbulkan kesalahpahaman. Meski masyarakat Indonesia beragam mulai dari suku, ras, etnik, bahasa dan agama, namun pengetahuan tentang keberagaman itu sendiri masih minim. Sedikit api pemantik perbedaan akan menimbulkan kerusuhan. Tindakan yang non produktif ini memicu pertikaian dan mengganggu keamanan bangsa Indonesia serta kehidupan antar umat beragama.

Maka Kementerian Agama memberikan edukasi di tengah masa pandemi Covid-19. Pengetahuan moderasi beragama kini digalakkan dengan memberikan kajiankajian moderasi beragama dalam lingkup pendidikan di madrasah. Para peserta didik perlu diberikan edukasi sejak dini dalam memaknai moderasi beragama. Literasi keagamaan dan berkebangsaan menjadi penyokong utama dalam pembelajaran. Pentingnya pendidikan moderasi beragama di Indonesia oleh Kementerian Agama disisipkan dalam kegiatan Pondok Ramadhan pada tahun ini. Dengan tingkat keberagaman yang majemuk, edukasi mengenai keberagaman di Indonesia memang menjadi fundament ketika dihadapkan dengan situasi Indonesia. Perlunya pendidikan moderasi beragama sejak dini agar para peserta didik mempunyai pengetahuan yang sesuai dengan nilainilai pancasila dan agama.

Karena kemerdekaan yang diraih bangsa Indonesia bukan serta merta milik kelompok tertentu, tapi dibentuk atas keberagaman yang ada di wilayah Negara Kesatuan Republik Indonesia. Kesatuan dan persatuan telah terwujud dengan adanya Pancasila sebagai dasar negara. Pancasila sebagai pedoman bangsa Indonesia adalah hal mutlak. Jika 
membubarkannya sama saja dengan membubarkan keseluruhan tatanan bangsa Indonesia yang kaya dengan keberagamannya. 


\section{MENUMBUHKAN ENTREPRENEURSHIP \\ INTENTION MAHASISWA MELALUI \\ PEMBELAJARAN DARING}

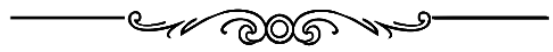

\section{Sufiana Noor, M.M9}

\section{IAIN Kudus}

"Periode pembelajaran daring di era pandemi menjadi momentum bagi proses belajar kewirausahaan bagi para dosen dan mahasiswa."

Pandemi Covid 19 telah memasuki babak baru dalam
segala aspek kehidupan masyarakat di seluruh dunia. Seluruh pelajar sudah mulai terbiasa dengan kegiatan belajar online dari rumah. Survey yang dilakukan Ditjen Dikti Kemendikbud kepada 230.000 mahasiswa di 32 provinsi di Indonesia pada bulan Maret 2020 menunjukkan 90\% responden memilih kuliah tatap muka. Mahasiswa memiliki alasan bervariasi mengapa mereka lebih memilih belajar secara tatap muka, tidak hanya karena jenuh, tetapi keterbatasan fasilitas yang mereka temui. Sinyal internet yang tidak mendukung, kuota internet yang cepat habis, gawai rusak karena terlalu sering digunakan kuliah online, dan sebagainya. Berbagai alasan tersebut sering dijumpai oleh para dosen ketika mendapati mahasiswa di kelasnya

${ }^{9}$ Penulis lahir di Kudus, 27 November 1988, penulis merupakan Dosen IAIN Kudus dalam bidang Manajemen Bisnis Syariah, penulis menyelesaikan gelar Sarjana Ekonomi di Universitas Diponegoro (2010), sedangkan gelar Magister Manajemen diselesaikan di Universitas Diponegoro Program Pascasarjana Magister Manajemen (2018). 
absen atau tiba-tiba menghilang dari media video conference.

Masalah keterbatasan fasilitas yang sering muncul ketika pembelajaran online menjadi hal yang wajar dan nyaris tanpa solusi. Sebagai seorang tenaga pengajar, dosen pasti ingin perkuliahan berjalan lancar dan materi yang disampaikan bisa diterima secara baik oleh mahasiswa. Masalah lain yang bisa direduksi oleh para dosen antara lain rasa jenuh yang dirasakan mahasiswa karena lelah kuliah online apalagi belajar online identik dengan tugas yang semakin banyak. Dosen berkesempatan memberikan penyampaian materi dan penugasan kepada mahasiswa dengan packaging menarik.

Kewirausahaan merupakan mata kuliah keterampilan umum yang wajib diberikan di setiap program studi. Salah satu capaian pembelajaran lulusan mata kuliah kewirausahaan adalah mahasiswa mampu menerapkan pemikiran logis, kritis, sistematis, dan inovatif dalam konteks pengembangan atau implementasi ilmu pengetahuan dan teknologi. Pada mata kuliah kewirausahaan mahasiswa belajar prinsip-prinsip dan cara yang digunakan untuk menjalankan usaha. Muara dari kuliah kewirausahaan adalah menumbuhkan semangat kewirausahaan dan minat berwirausaha. Jika hal tersebut terwujud, tentunya akan memberikan kontribusi kepada perekonomian masyarakat. Pembentukan dan pengembangan Usaha Mikro, Kecil, dan Menengah (UMKM) tumbuh dari jiwa kewirausahaan yang tinggi. Kuliah kewirausahaan diharapkan dapat mendorong minat mahasiswa untuk berwirausaha.

Kewirausahaan adalah suatu ilmu yang mengkaji tentang pengembangan dan pembangunan semangat kreativitas serta berani menanggung resiko terhadap 
pekerjaan yang dilakukan demi mewujudkan hasil karya (Fahmi, 2016). Douglas dan Fitzsimmon (2008) dalam Zain et al (2010) berpendapat bahwa entrepreneurship intention mengacu pada tindakan dari tiap individu terhadap hasil dari tindakan tersebut dan self efficacy. Self efficacy diartikan sebagai keyakinan atau kepercayaan individu mengenai kemampuan dirinya untuk mengatur, melaksanakan suatu tugas, mencapai suatu tujuan, menghasilkan sesuatu dan mengimplementasikan tindakan untuk menunjukkan kecakapan tertentu. (Bandura, 1997 dalam Kisti \& Fardana N, 2012).

Periode pembelajaran daring di era pandemi menjadi momentum bagi proses belajar kewirausahaan bagi para dosen dan mahasiswa. Dalam proses pembelajaran daring, penugasan tahap awal pada kuliah kewirausahaan menitikberatkan pada aspek pemahaman konsep kewirausahaan dilanjutkan bagaimana memulai usaha termasuk perencanaan produk, strategi merek, dan distribusi. Mahasiswa yang tadinya hanya belajar dari textbook diarahkan untuk mulai menganalisis konsep kewirausahaan dari jurnal yang relevan. Mahasiswa belajar mandiri tentunya dengan bimbingan dari dosen pengampu tentang teori kewirausahaan hingga case study misal; bagaimana melakukan riset, menyusun perencanaan usaha, kendala dalam perencanaan usaha, serta mencontohkan analisis SWOT.

Kreativitas mahasiswa dalam mengimplementasikan strategi merek atau dalam jangkauan yang lebih luas, bagaimana melakukan strategi pemasaran bagi usaha mereka menggunakan media sosial dan marketplace. Cara tersebut terbilang nyaris tanpa biaya. Mahasiswa generasi Z cenderung lebih menyukai hal simpel, fleksibel, dan berkaitan dengan kemajuan teknologi. Bukan lagi hal yang 
aneh, jika generasi $\mathrm{Z}$ sudah memiliki kemampuan foto produk hingga menjual produk secara online hanya dengan berbekal smartphone. Di era saat ini, teknologi digital mendominasi peradaban manusia apalagi dalam kegiatan perekonomian. Mahasiswa yang sedang mengikuti kuliah daring bisa menjadi wirausaha tanpa modal besar.

Pada saat pembahasan mengenai strategi perencanaan produk, strategi merek, dan distribusi dalam mata kuliah kewirausahaan, mahasiswa diberi tugas kelompok untuk brainstorming agar menghasilkan gagasan kreatif yang dapat diterapkan pada era digital. Mengadopsi dari materi yang disampaikan Rusli Fauzi, Analis Rencana Program Kegiatan PPIP LIPI dalam webinar serial Digital Content Marketing: "Branding dan Komunikasi Produk Era Digital" pada awal bulan Mei 2020. Mahasiswa melakukan lima langkah era digital yang diuraikan pada gambar di bawah ini.

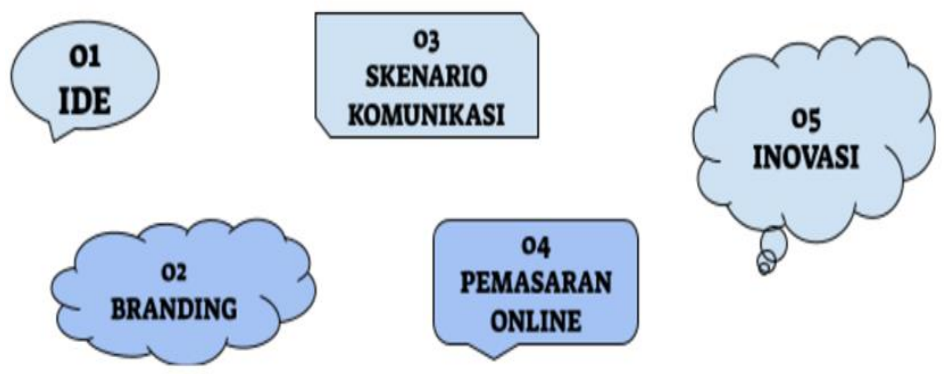

Gambar 1 Lima Langkah Era Digital

1. Ide, mahasiswa menentukan ide produk/jasa yang akan dijual

2. Branding, melakukan branding ide. Mahasiswa memvisualisasikan visi ke dalam suatu merek sehingga memiliki value agar memberikan manfaat dan solusi. 
3. Skenario Komunikasi, mahasiswa menceritakan keunikan dari produk/jasa tersebut. Mahasiswa mempelajari hal-hal terkait personal branding untuk mendukung produk/jasa yang dijual.

4. Pemasaran online, mahasiswa berinteraksi dengan target pasar yang telah ditentukan. Komunikasi dua arah dapat dilakukan dengan digital marketing. Mahasiswa memanfaatkan media sosial dan layanan pesan instan yang relatif tanpa biaya.

5. Inovasi, mahasiswa mengeksplorasi hal-hal baru dari tahap sebelumnya. Mahasiswa berkolaborasi dan mengembangkan rencana yang sudah ada agar lebih efektif dalam menjual produk/jasa.

Selama proses menyusun perencanaan produk, kreativitas dan motivasi mahasiswa sangat diperlukan agar ide yang dihasilkan bisa diimplementasikan. Dosen senantiasa mengawasi, mengarahkan dan mengevaluasi proses tersebut. Tugas membuat desain produk dan strategi merek menjadi kegiatan yang user friendly. Likability dari sosial media merupakan salah satu hal yang erat dengan keseharian mahasiswa. Sebagian besar mahasiswa sudah familiar dengan aplikasi desain dan aplikasi penyunting video. Kemampuan dalam mengolah gambar dan video sangat mendukung perencanaan produk dan strategi merek.

Penugasan yang lebih eksploratif dan variatif akan meningkatkan minat belajar mahasiswa. Pekerjaan rumah bagi para dosen pengampu adalah bagaimana mengemas penugasan yang tidak memberatkan mahasiswa tapi dapat memaksimalkan potensi diri mahasiswa serta sesuai 
dengan karakter kelas yang diampu. Mahasiswa yang rutin melakukan vlog, berkreasi lewat aplikasi TikTok, membagikan gambar/video di Instagram dengan caption menarik, dan seterusnya, bukanlah hanya sekedar hobi atau kesenangan. Dengan pendekatan yang komprehensif, hobi atau kesenangan tersebut berubah menjadi potensi bisnis. Mahasiswa yang mampu konsisten dalam memanfaatkan potensi bisnis lewat sosial media akan menjadi wirausaha. Bahkan mahasiswa yang tadinya hanya belajar teori akan mulai mencari tahu 'bagaimana menjadi wirausaha'. 


\section{Daftar Pustaka}

Fahmi, Irham. 2015. Kewirausahaan: Teori, Kasus dan Solusi. Bandung: Alfabeta.

Kisty, Hepy Hapsari dan Nur Ainy Fardana N. 2012. "Hubungan Antara Self Efficacy dengan Kreativitas Pada Siswa SMK". Jurnal Psikologi Klinis dan Kesehatan Mental Vol. 1 No. 02, Juni 2012.

Zain, Zahariah Mohd, Amalina Mohd Akram, dan Erlan K. Ghani. 2010. "Entrepreneurship Intention Among Malaysian Business Students". Canadia Social Science Vol. 6 No $3 . \quad$ Doi: 10.3968/j.css.1923669720100603.004

Maharani, Tsarina. 2020. "Survei Kemendikbud: 90\% Mahasiswa Pilih Kuliah Tatap Muka". https://nasional.kompas.com/read/2020/07/09/1 2330921/survei-kemendikbud-90-persenmahasiswa-pilih-kuliah-tatap-muka, diakses pada 7 Mei 2021 pukul 10.00

Inovasi. 2020. "Digital Content Marketing: Branding dan Komunikasi Produk Era Digital". https://ppii.lipi.go.id/2020/05/07/digital-contentmarketing-branding-dan-komunikasi-produk-eradigital/, diakses pada 9 Mei 2021 pukul 22.00. 


\section{EKSISTENSI ILMU KIMIA DAN PEMBELAJARANNYA DALAM MASA PANDEMI

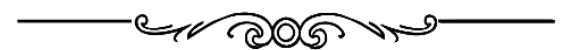

M.A Yohanita Nirmalasari, S.Si., M.Pd.10

Pendidikan Kimia, Universitas Nusa Nipa

"Kimia menjadi sesuatu yang sulit dan abstrak apabila konsep sederhana dibuat rumit dengan minimnya metode atau model pembelajaran."

\section{Kimia dalam Kehidupan}

ayaknya suatu elemen atau unsur kimia, ilmu kimia
hadir di tengah situasi kehidupan manusia sebagai pembentuk suatu molekul yang dinamakan dengan 'molekul kehidupan'. Ilustrasi ini kian membuka ruang publik untuk menyadari eksistensi kimia sebagai bagian ilmu yang berperan penting dalam kehidupan. Sebagai suatu ilmu yang memiliki roh pada kajian zat, energi dan perubahan semesta, pemahaman kimia tentunya menjadi kebutuhan setiap kita yang berada pada rahim semesta.

10Penulis lahir di Larantuka, 17 Juli 1988, penulis merupakan Dosen Pendidikan Kimia FKIP Universitas Nusa Nipa. Penulis menyelesaikan gelar Sarjana Sains dalam bidang Kimia di Universitas Udayana (2011), gelar Magister Pendidikan di Universitas Negeri Yogyakarta Program Studi Pendidikan Kimia (2016). Penulis mengampu mata kuliah kimia anorganik, media pembelajaran kimia dan pemroduksian bahan ajar kimia. Dalam bidang penelitian, penulis berturut-turut lolos hibah penelitian dosen pemula pada tahun 2020 dan 2021 dengan menghasilkan produk buklet dan e-UKBM kimia. Penulis aktif menyumbangkan ide pada berbagai jurnal ilmiah terakreditasi DIKTI dan buku baik monograf dan book chapter. 
Dalam ilmu kimia, manusia dapat dianggap makromolekul (molekul besar) yang tersusun atas ribuan mikromolekul (molekul kecil) hingga sampai pada tingkatan terkecil, yakni partikel. Bagaimana memahami tubuh dalam kajian sistem dan interaksinya dengan sesuatu diluar sistem (lingkungan) dapat dijembatani melalui pemahaman studi kimia.

Transfer pemahaman kimia dapat dilakukan melalui proses pembelajaran kimia. Sasaran pembelajaran kimia yang diatur dalam kurikulum pendidikan formal adalah siswa SMA/MA. Namun, sesungguhnya pengetahuan kimia bermanfaat untuk semua orang. Belajar kimia diperlukan untuk anak usia dini hingga lansia dengan kadar dan tingkatan materi yang berbeda sesuai fase kehidupan. Pemikiran ini muncul karena melihat segala sesuatu yang hidup berkaitan langsung dengan kimia. Sebagai contoh, air yang menjadi kebutuhan utama manusia. Bumi yang menjadi pijakan dan hunian manusia sebagian besar mengandung komponen air. Manusia awam hanya mengetahui sebatas air dimana air itu mengalir dan dapat mengalami perubahan suhu menjadi panas hingga dingin dan sebaliknya. Namun, elemen penyusunnya dan bagaimana sifat serta reaksi sederhana air tentu tidak akan dikenal jika tidak diperkenalkan.

Kimia menjadi sesuatu yang sulit dan abstrak apabila konsep sederhana dibuat rumit dengan minimnya metode atau model pembelajaran. Manusia umumnya menganggap kimia sebagai ilmu dengan level kesulitan tinggi yang mengandung sekian banyak rumus dan perhitungan. Alangkah baiknya paradigma ini diubah dengan mindset bahwa kimia itu sesederhana membuka mata semenjak beranjak dari tidur pagi, melakukan aktivitas apapun seharian dan sampai pada waktu malam kembali 
beristirahat. Siklus hidup ini tanpa disadari membawa pada pengalaman proses kimia.

Ide sederhana diungkapkan oleh Subagia (2014) tentang mudahnya belajar kimia hanya dengan kata kunci: "Jangan Mengatakan". Ini adalah kalimat negatif yang akan menyalurkan energi serupa dan membuat orang takut dan mundur sebelum berperang. Catatan pentingnya bahwa untuk suatu proses pembelajaran baiknya menghindari pemberian kalimat negatif. Afirmasi disertai tindakan dapat dimanfaatkan untuk memberikan aura dan energi positif dalam membangun motivasi dan minat untuk mengeksplor pengetahuan. Ulasan kata kunci tersebut dapat ditelaah dalam beberapa poin, sebagai berikut.

1. Jangan mengatakan kimia itu sulit, melainkan katakanlah kimia itu penting (life is chemistry);

2. Jangan mengatakan kimia itu membahayakan, melainkan katakanlah kimia itu menyejahterakan;

3. Jangan mengatakan kimia itu menyeramkan, melainkan katakanlah kimia itu menyenangkan;

4. Jangan mengatakan kimia itu menyakitkan, melainkan katakanlah kimia itu menyehatkan;

5. Jangan mengatakan kimia untuk sebagian orang, melainkan katakanlah kimia untuk semua orang;

Pendapat Subagia pun dapat dirangkum menjadi suatu kalimat yang membangkitkan semangat dan merubah paradigma lama tentang belajar kimia. Kalimat dapat menjadi: "Kimia merupakan ilmu yang penting untuk semua orang, bukan kalangan tertentu. Mengenal kimia akan membuat kita lebih mengenal hidup dan menghargainya, 
hidup lebih sejahtera, sehat dan menyenangkan." Paradigma ini selanjutnya dapat diterapkan dalam situasi pembelajaran kimia pada masa pandemi.

\section{Belajar Kimia pada Masa Pandemi}

Ketika bencana pandemi covid 19 atau yang dikenal dengan wabah korona menyerang beberapa negara termasuk Indonesia, dunia dan kehidupan menjadi risau, cemas dan gelisah termasuk proses pendidikan. Pembelajaran yang semula dengan pola tatap muka tidak dapat dilanjutkan sebagaimana biasanya. Pemerintah melalui kebijakannya, merekomendasikan beberapa pola pembelajaran untuk menghindari kerumunan kelompok belajar yang besar dengan tetap mengupayakan terlaksananya proses pembelajaran. Rekomendasi pembelajaran seperti PJJ (pembelajaran jarak jauh), dan blended learning (pembelajaran daring dan luring) yang melibatkan Learning Management System (LMS), antara lain google class room, schoology, edmodo, socrative, microsoft office 365 dan lainnya.

Dalam konteks pembelajaran kimia, ada dua hal pokok yang mau disampaikan dalam tulisan ini, yakni penyesuaian paradigma pembelajaran pada masa pandemi dan penyesuaian IPTEKS dalam mempertahankan eksistensi pembelajaran kimia.

1. Penyesuaian Paradigma Pembelajaran Kimia

Dampak pandemi covid 19 membias kemanapun dan siapapun termasuk siswa dan guru. Sebagian besar adalah penganut keras gaya lama paradigma kimia yang serba sulit dan tidak dapat teratasi. Energi negatif keduanya menarik hal serupa dan pada akhirnya kimia menjadi sulit ditelan korona. Hal ini dapat menjadi masalah diatas masalah dalam kerumitan mekanisme pembelajaran. Dalam keadaan demikian, sebuah kutipan yang inspiratif bahwa emas akan 
tetap berkilau di dalam lumpur sekalipun dapat menyelamatkan keadaan dan menciptakan loncatan strategi. Kutipan ini seketika membawa kekuatan energi untuk melakukan eksitasi layaknya promosi elektron di dalam teori hibridisasi.

Solusi yang dapat ditempuh adalah dengan menggali kembali metode pembelajaran berbasis budaya dalam konteks ilmu kimia yang disebut dengan etnokimia. Jadi, belajar kimia akan menjadi mudah, sederhana dan menyenangkan apabila dimulai dari diri sendiri dan budaya lingkungan sekitar. Segala sesuatu dalam diri dan lingkungan tempat kita hidup adalah laboratorium kimia. Metode ini selaras dengan pendekatan pembelajaran kontekstual, belajar dalam konteks kehidupan sehari-hari. Pendapat Nirmalasari dalam buku strategi pembelajaran (Rachmawati.,dkk, 2020) menyorotkan kembali peran etnokimia dalam pembelajaran kimia dengan mengaitkan kimia dan budaya Flores. Banyak unsur kebudayaan setempat yang apabila ditautkan dengan ilmu kimia menjadi pengetahuan utuh yang saling melengkapi. Dengan demikian, situasi pandemi covid 19 adalah jalan tol atau katalisator untuk kembali mengenal alam sekitar dalam perspektif konten budaya dan kimia.

Pada akhirnya, jangan membangun sebuah pemikiran dan terjebak sendiri dengan pemikiran tersebut bahwa kimia itu sulit. Jika sederhananya kimia itu menyentuh kehidupan pada waktu pagi hingga malam maka secara tidak langsung kita membawa kimia dalam hidup kita. Mengenal kimia sama dengan mengenal kehidupan dari awal hingga akhir. Aktivitas seperti makan, minum, olahraga, berlari dan sebagainya melibatkan komponen zat, unsur, senyawa dan molekul kimia. Tidak hanya itu, proses dan perubahan energi yang terjadi pun adalah kimia. Oleh 
karena itu, tidak semua hal kimia adalah turunan rumus yang rumit, segalanya dapat dipermudah dengan pendekatan pembelajaran yang sesuai.

2. Penyesuaian Kemampuan Teknologi Digitalisasi

Teknologi digitalisasi terkini menjadi sektor penting proses pembelajaran. Selain dihadapkan pada era milenial pembelajaran 5.0, peran teknologi semakin dibutuhkan oleh pembelajaran pada masa pandemi. Teknologi sebagai alat penyampaian informasi dan komunikasi (pengetahuan), diskusi pemecahan masalah bahkan penilaian pembelajaran. Pandemi menekan laju pertemuan tatap muka dalam skala besar, sehingga teknologi adalah satusatunya alat vital pembelajaran. Pelaku pembelajaran dalam hal ini guru dan siswa harus mampu menyesuaikan diri dengan perubahan zaman untuk mendekatkan diri dengan teknologi masa kini. Zaman berubah, pola manualisasi beralih pada digitalisasi, semua serba online. Masa pandemi mengakibatkan mekanisme pembelajaran kimia mengalami perubahan yang signifikan. Pola luring dengan metode tatap muka dalam segala bentuk pembelajaran seperti diskusi terbuka, praktikum berkelompok, presentasi proyek dan lainnya tidak dapat dilaksanakan seperti sebelum masa pandemi. Akibatnya, proses pembelajaran diubah ke dalam sistem daring dengan memanfaatkan teknologi digital.

Dalam keseharian pembelajaran kimia untuk mahasiswa pendidikan kimia, awalnya menggunakan bantuan google class room. Proses ini cukup membantu namun tidak efektif untuk pembelajaran materi kimia. Keterbatasannya, yakni tidak memungkinkan tatap muka dalam jaringan online, sehingga informasi pengetahuan tidak sempurna sampai pada mahasiswa. Pembelajaran dengan google class room kemudian dilengkapi dengan 
akun microsoft teams untuk dosen dan mahasiswa sebagai solusi pembelajaran kimia. Kelebihannya, yakni dapat menggantikan proses tatap muka dengan mengeksplorasi materi dan diskusi interaktif. Namun, untuk materi kimia tertentu, perlu bantuan tools untuk menggambarkan model atom, molekul dan lainnya. Dengan demikian, adanya pen tab sangat bermanfaat dalam memfasilitasi pembelajaran kimia. Semua proses pembelajaran akan terlaksana dengan baik juga memerlukan koneksi internet dan fasilitas pendukung pembelajaran. 


\section{Daftar Pustaka}

Rachmawati, R., Nirmalasari, M.A.Y., Rif'ati, B., Kartikawati,

D., Mayasari, D., \& Massang, B. 2020. Strategi

Pembelajaran. Surabaya: CV. Jakad Media Publishing.

Subagia, I.W. 2014. Paradigma Baru Pembelajaran Kimia SMA. Seminar Nasional F MIPA UNDIKSHA IV. 152163. 


\title{
ANALISIS AKUNTANSI KEPERILAKUAN PADA PEMBELAJARAN PROGRAM STUDI AKUNTANSI
}

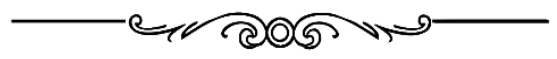

Ita Rakhmawati11

IAIN Kudus

\begin{abstract}
"Sebagai sebuah paradigma integratif, akuntansi keperilakuan menaungi banyak proses pengambilan keputusan di sebuah entitas baik pada tataran top management bahkan lower management."
\end{abstract}

\begin{abstract}
A kuntansi sering disebut sebagai bahasa bisnis (language of business). Hal ini dikarenakan informasi yang dihasilkan oleh akuntansi mampu menyatakan apa yang terjadi pada sebuah perusahaan. Pada saat ini, akuntansi berkembang seiring dengan perkembangan dunia bisnis di masyarakat. Perkembangan akuntansi saat ini tidak hanya terkait menghasilkan informasi keuangan tetapi juga mampu menghasilkan informasi non keuangan yang penting sebagai dasar pengambilan keputusan oleh stakeholder. Dengan demikian akuntan (person) sebagai pelaku dalam pengelolaan akuntansi menjadi salah satu unsur utama yang akan menentukan kualitas informasi yang dihasilkan.
\end{abstract}

11Penulis Lahir di Kudus, 18 April 1986. Saat ini bekerja sebagai dosen di IAIN Kudus Fakultas Ekonomi dan Bisnis Islam dalam bidang kompetensi akuntansi dan ekonomi. Penulis memperoleh gelas S1 Pendidikan Ekonomi dari Universitas Negeri Semarang serta gelar s2nya pada magister akuntansi dari Sekolah Tinggi Ilmu Ekonomi Dharmaputra Semarang. 
Akuntansi keperilakuan (behavior accounting) merupakan salah satu bidang dalam rumpun ilmu akuntansi yang membahas hubungan antara manusia dengan berbagai aspek perilakunya, berinteraksi dengan sistem akuntansi dalam suatu entitas. Aspek keperilakuan ini dapat mempengaruhi cara pandang akuntan terhadap data data keuangan yang diolahnya. Dengan demikian akuntansi keperilakuan bersifat integratif terhadap berbagai bidang kajian akuntansi. Hal ini dikarenakan setiap bidang kajian akuntansi pasti melibatkan unsur perilaku individu dalam pengambilan keputusan (decision maker). Perilaku akuntan tersebut selalu bersifat dinamis seiring perkembangan pengetahuan, teknologi dan lingkungan.

Menurut Lubis akuntansi keperilakuan merupakan sub disiplin ilmu akuntansi yang melibatkan beberapa aspek keperilakuan manusia yang berkaitan dengan proses pengambilan sebuah keputusan ekonomi (Arfan Ikhsan, 2017). Dengan demikian, akuntansi keperilakuan tidak hanya terkait dengan apa yang terjadi tetapi juga harus mampu mengungkap yang ada dibalik yang sedang terjadi. Pengkajian dan penelitian terkait dengan akuntansi keperilakuan pada dekade 20-an ini menjadi lebih mendalam dan menarik setelah munculnya isu isu strategis terkait dengan pelanggaran kode etik yang sangat riskan dilakukan oleh seorang akuntan. Seperti halnya kasus manipulasi laporan keuangan yang terjadi di PT KAI tahun 2005 silam, kasus laporan keuangan ganda Bank Lippo tahun 2002 dan lainnya.

Dalam teori atribusi yang dikembangkan oleh Heider, yang menyatakan bahwa perilaku individu lebih direpresentasikan sebagai kombinasi antara kekuatan internal dan kekuatan eksternal (Heider, 1958). Kekuatan 
internal merupakan kekuatan yang berasal dari dalam diri individu itu sendiri. Kekuatan internal ini pada umumnya berupa kemampuan, pengetahuan, dan usaha. Sedangkan kekuatan eksternal merupakan kekuatan yang berasal dari luar individu. Kekuatan eksternal ini lebih berasal dari tekanan pada situasi atau keadaan di luar individu itu yang memaksa untuk melakukan suatu tindakan. Sedangkan menurut Seigel dan Marconi terdapat beberapa faktor sosiologi, psikologi dan psikologi sosial yang relevan terhadap akuntansi keperilakuan, yang meliputi: sikap, motivasi, persepsi, pembelajaran dan kepribadian (Siegel, 1989).

Keberadaan akuntansi yang menjadi sangat vital karena tidak hanya memberikan data bersifat kuantitif saja melainkan harus dapat mengungkap secara kualitatif terhadap makna apa yang terjadi di baliknya. Hal ini mendorong perlunya kerangka teknik yang kuat dalam pengembangannya. Menurut lubis akuntansi keperilakuan menyediakan kerangka yang tersusun atas beberapa teknik yaitu meliputi (Arfan Ikhsan, 2017):

1. Memahami dan mengukur suatu dampak dari proses bisnis, terhadap beberapa orang dan kinerja perusahaan.

2. Untuk mengukur dan melaporkan suatu perilaku dan juga pendapat yang relevan terhadap suatu perencanaan strategis

3. Untuk mempengaruhi pendapat dan juga perilaku yang digunakan untuk memastikan keberhasilan sebuah implementasi kebijakan perusahaan.

Sebagai sebuah paradigma integratif, akuntansi keperilakuan menaungi banyak proses pengambilan keputusan di sebuah entitas baik pada tataran top 
management bahkan lower management. Akuntan memiliki tugas utama untuk mengolah data keuangan menjadi informasi keuangan. Hasil analisis informasi keuangan yang dilakukan oleh akuntan menjadi bahan pertimbangan penting bagi pengambilan keputusan (decision making) para stakeholder. Berdasarkan bidang dan cakupannya, akuntan di dalam perusahaan memiliki tugas dan ruang lingkup pekerjaan antara lain sebagai berikut:

1. Melakukan pencatatan transaksi keuangan dan penyusunan laporan keuangan untuk kepentingan pihak eksternal ( laporan laba rugi, laporan perubahan ekuitas, laporan posisi keuangan dan laporan arus kas)

2. Menganalisa biaya yang dikeluarkan perusahaan terkait dengan penentuan harga pokok produk dan juga pengawasan biaya

3. Menyusun perencanaan keuangan jangka pendek dan jangka panjang dalam rangka perencanaan laba (profit planning) sebagai dasar operasional perusahaan

4. Menganalisa besarnya pajak yang harus dibayarkan oleh perusahaan

5. Merancang sistem informasi akuntansi yang terintegratif, handal dan representatif untuk menunjang operasional perusahaan

6. Melakukan pemeriksaan pelaksanaan akuntansi sesuai dengan standar akuntansi keuangan yang berlaku.

Perguruan tinggi dalam hal ini program studi sebagai pencetak sumber daya manusia yang akan mengisi permintaan dunia kerja diharapkan mampu menghasilkan lulusan yang kompeten, profesional serta beratitude dalam 
bidang keilmuannya. Aspek keperilakuan dalam akuntansi tidak hanya dialami oleh akuntan sebagai pengambil keputusan strategis di dunia kerja. Aspek ini juga sudah mulai timbul dan harus diarahkan mulai dari tingkat bangku perkuliahan. Mahasiswa program studi akuntansi yang memiliki profil lulusan sebagai tenaga ahli di bidang akuntansi diharapkan saat terjun ke dunia kerja nantinya mampu memiliki integritas serta kepatuhan kepada kode etik profesinya. Oleh karena itu penting sekali mahasiswa dibekali dengan berbagai aspek etis dalam dunia perkuliahan sejak dini.

Salah satu frame untuk mengungkap bagaimana aspek keperilakuan pada diri seorang akuntan adalah menggunakan teori utilitas. Menurut Teori Utilitas (yang sering disebut juga sebagai teori manfaat yang diharapkan) yang dikemukakan oleh Neumann dan Morgestern dalam Suartana menyatakan bahwa bagaimana seseorang akan berperilaku jika harus mengikuti persyaratan tertentu dalam pembuatan keputusan yang bersifat rasional, bukan untuk menggambarkan bagaimana orang orang benar benar berperilaku (Suartana, 2010). Hal ini didasarkan atas enam prinsip dasar dalam tingkah laku memilih yaitu adanya urutan alternatif, dominasi / kekuasaan, cancellation, transitivitas, kontinuitas, dan invariance.

Berdasarkan teori utilitas tersebut dapat diturunkan menjadi tiga indikator utama yaitu pengambilan keputusan, penguasaan atas pengetahuan dan informasi dari semua peristiwa yang tidak diamati. Mahasiswa program studi akuntansi harus mampu mengambil keputusan yang didasarkan atas peraturan yang berlaku (standar akuntansi) yang cukup dinamis mengalami perbaikan. Kecepatan mahasiswa dalam merespon perubahan PSAK sangat penting sebagai dasar pengambilan keputusan yang 
tepat. Hal tersebut dapat dibuktikan melalui ketepatan mahasiswa menyelesaikan berbagai contoh kasus yang diberikan selama proses perkuliahan. Selain itu mahasiswa harus memiliki kesiapan untuk mengimplementasikan ilmunya dalam praktek di lapangan dengan berbagai tantangan situasi eksternal yang uncontrollable.

Pada aspek penguasaan atas pengetahuan, mahasiswa dituntut untuk mampu menghitung, menyusun dan memberikan laporan keuangan yang relevan; mengendalikan laporan keuangan; serta menghitung dan mengelola biaya produksi dan biaya operasional. Sedangkan pada aspek informasi dari semua pihak yang tidak diamati, mahasiswa akuntansi harus mampu mengidentifikasi terkait berbagai informasi ekonomi yang relevan dengan pengambilan keputusan. Informasi ini secara langsung atau pun tidak langsung menjadi salah satu aspek pertimbangan akuntan. Informasi informasi luar ini akan mendukung keakuratan dalam peramalan laporan keuangan di masa yang akan datang dengan melakukan pengintegrasian pendekatan berbasis peristiwa dengan pendekatan berbasis data.

Dengan demikian aspek utama yang menjadi perhatian dalam pembelajaran mata kuliah akuntansi keperilakuan adalah bagaimana interaksi antara sistem akuntansi, perilaku manusia serta karakteristik organisasi terhadap lingkungannya. Hal ini menuntut bentuk pembelajaran yang lebih mengasah tingkat keaktifan mahasiswa. Salah satu bentuk pembelajaran yang sampai saat ini dirasakan lebih efektif dalam memahami aspek keperilakuan dalam akuntansi adalah melalui case based learning. Kenapa case based learning?

Case based learning merupakan salah satu metode pembelajaran yang memberikan kesempatan besar bagi 
mahasiswa untuk berperan aktif. Kasus merupakan miniatur dari kondisi nyata yang ada di lapangan sehingga cukup representatif untuk menggambarkan kondisi sosial yang sedang terjadi. Kasus akan mendorong individu individu yang terlibat didalamnya untuk saling berinteraksi dan berkolaborasi. Melalui kasus juga dilatih untuk melakukan analisis secara mendalam serta mampu mengintegrasikan berbagai pengetahuan dan kemampuan yang dimiliki untuk menghasilkan berbagai alternatif penyelesaian. Dengan demikian sense of judgement mahasiswa menjadi lebih terasah. 


\section{Daftar Pustaka}

Arfan Ikhsan, L. (2017). Akuntansi Keperilakuan; akuntansi multiguna. Salemba empat.

Heider, F. (1958). The Psychology of Interpersonal Relations. Wiley.

Siegel, G. dan H. R. M. (1989). Behavioral Accounting. SouthWestern Publishing Co.

Suartana, I. W. (2010). Akuntansi Keperilakuan Teori dan Implementasi. Andi Offset. 


\section{BAB II: \\ REALITA PEMBELAJARAN DARING}

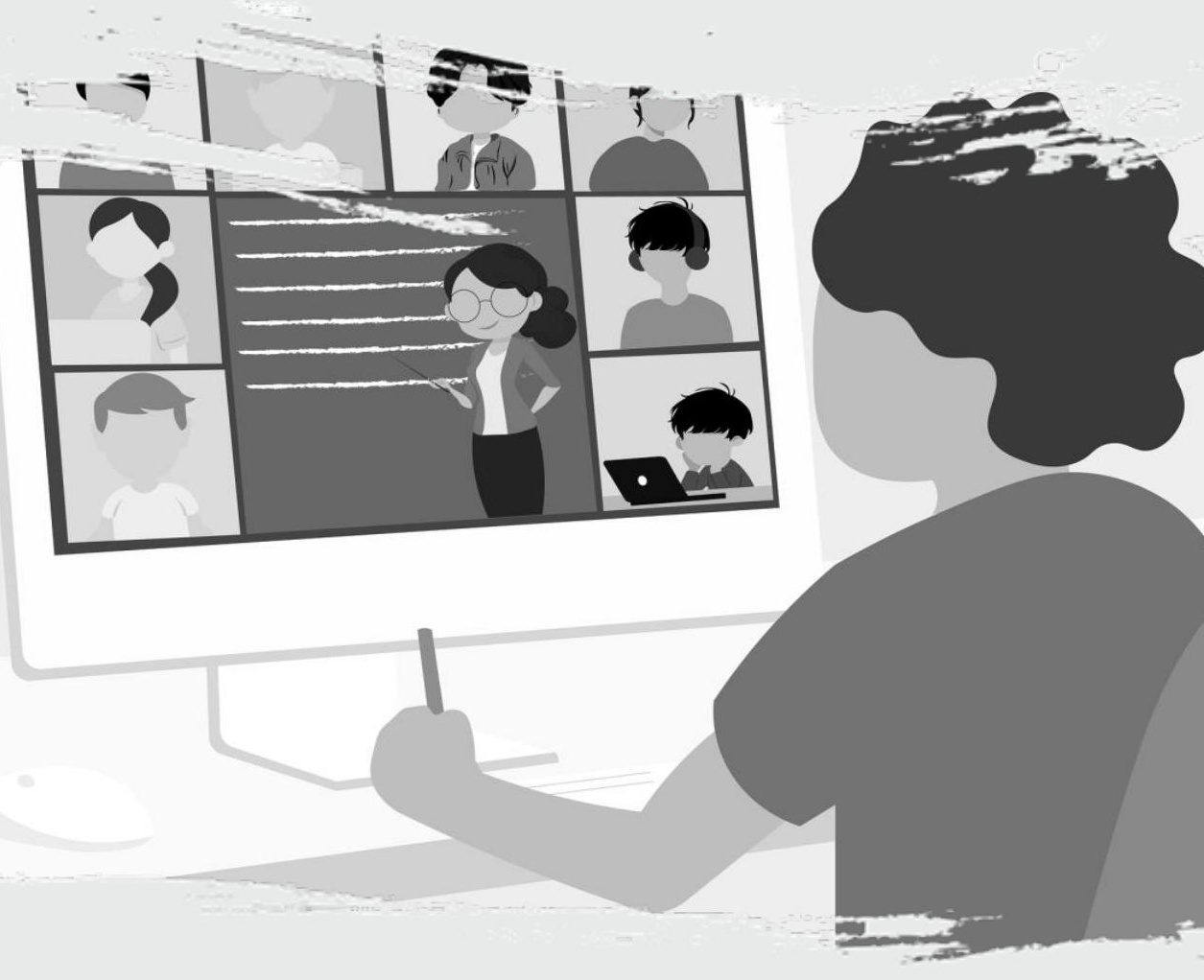




\title{
PENGEMBANGAN MODEL PEMBELAJARAN ONLINE PADA MASA PANDEMI COVID-19 DI DAERAH 3T DI MALUKU
}

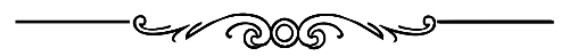

\author{
Dr. Saidna Zulfiqar Bin Tahir, Lc., M.Pd., Ph.D12 \\ Universitas Iqra Buru, Maluku
}

\begin{abstract}
"Tidak semua sekolah, lokasi dan provinsi di Indonesia memiliki fasilitas dan kapasitas yang sama. Tidak semua teori dan model pembelajaran dapat diaplikasikan pada sekolah dan daerah yang berbeda situasi dan lokasi. Hal ini memaksa pendidik untuk mencari inovasi untuk mendukung kegiatan belajar mengajar khususnya di daerah terpencil atau $3 T^{\prime \prime}$
\end{abstract}

Saat ini, wabah virus Corona 2019 (COVID-19) sudah tidak lagi dihiraukan oleh masyarakat karena kebosanan dan lama menunggu vaksin. Sejak WHO menyatakan wabah ini sebagai pandemi global pada 11 Maret 2020. Beberapa pemerintah daerah di Indonesia telah memutuskan untuk menerapkan kebijakan memberhentikan aktifitas pembelajaran di sekolah dan menerapkan metode

12Saidna Zulfiqar Bin-Tahir adalah dosen Jurusan Pendidikan Bahasa Inggris Universitas Iqra Buru, Indonesia. Bidang minat dan penelitiannya meliputi media pengajaran, TEFL, Bahasa Arab dan Linguistik, dan Pendidikan Multilingual. Ia lulus dari Universitas Al-Azhar Kairo dalam bidang Bahasa dan Linguistik Arab dan menyelesaikan gelar master dan doktoralnya dari Universitas Negeri Makassar pada Jurusan Pendidikan Bahasa Inggris dan memperoleh beasiswa PKPI di Northern Illinois University, Amerika Serikat. 
pembelajaran online atau e-learning. Kebijakan pemerintah tersebut mulai berlaku di beberapa provinsi pada hari Senin tanggal 16 Maret 2020, diikuti oleh provinsi lainnya. Namun hal tersebut tidak berlaku untuk beberapa sekolah di setiap daerah, terutama di daerah terpencil atau daerah 3T. Sekolah-sekolah tersebut belum siap dengan sistem pembelajaran online yang digagas pemerintah karena kebutuhan media pembelajaran seperti jaringan internet, handphone, laptop, atau komputer.

Pembelajaran online tidak lepas dari jaringan internet. Koneksi jaringan internet merupakan salah satu kendala yang dihadapi siswa yang tempat tinggalnya kesulitan mengakses internet, terutama karena mereka tinggal di pedesaan, terpencil, dan daerah tertinggal. Kalaupun seseorang menggunakan jaringan seluler, terkadang jaringan tersebut tidak stabil karena letak geografis yang masih jauh dari jangkauan sinyal seluler. Hal tersebut juga menjadi masalah yang sering terjadi pada siswa yang mengikuti pembelajaran online tidak maksimal dalam pelaksanaannya.

Beberapa hasil penelitian tentang pembelajaran selama periode Covid-19 merekomendasikan adanya transformasi media pembelajaran agar kegiatan pembelajaran dapat berlangsung secara efektif (Atsani, 2020). Ayuni dkk. (2020) menganalisis belum adanya kesiapan guru dalam menghadapi pembelajaran selama pandemi Covid-19. Selain itu, Astini (2020) mengemukakan pemanfaatan teknologi informasi dalam dunia pendidikan. Sementara itu, Allo (2020) masih meragukan pembelajaran online untuk diterapkan, meski hasil penelitiannya menunjukkan peningkatan hasil belajar.

Beberapa dari penelitian sebelumnya ini telah mencoba memberikan solusi untuk pembelajaran selama 
pandemi Covid-19. Sayangnya mereka belum melihat bagaimana pembelajaran di daerah terpencil yang tidak memiliki jaringan internet atau memiliki akses, yang seringkali terjadi kendala dalam koneksi. Mereka juga belum menganalisis bagaimana siswa tidak memiliki akses internet, ponsel atau android, dan laptop. Oleh karena itu, tulisan ini mencoba menganalisis kebutuhan siswa dan guru serta kondisi sekolah. Peneliti merancang model pembelajaran yang sesuai untuk diterapkan di sekolahsekolah yang berada di daerah terpencil dari hasil analisis ini.

\section{Model Pembelajaran masa Pandemi Covid-19}

Pasca wabah Covid-19 di belahan bumi, sistem pendidikan mulai mencari inovasi dalam proses belajar mengajar. Apalagi, Surat Edaran no. 4 Tahun 2020 dari Mendikbud merekomendasikan agar semua kegiatan lembaga pendidikan menjaga jarak. Semua pengiriman material akan dikirim di rumahnya masing-masing. Beberapa metode yang direkomendasikan pemerintah dapat digunakan dalam pembelajaran selama pandemi, di antaranya:

1. Pembelajaran berbasis proyek ini diprakarsai sebagai implikasi Surat Edaran Menteri Pendidikan dan Kebudayaan Nomor 4 Tahun 2020. Pembelajaran berbasis proyek ini memiliki tujuan utama memberikan pelatihan kepada siswa agar lebih mampu berkolaborasi, bekerja sama, dan berempati. dengan orang lain.

2. Metode online memanfaatkan jaringan online dan dapat membuat siswa kreatif menggunakan fasilitas yang ada, seperti membuat konten dengan menggunakan 
barang-barang yang ada di sekitar rumah atau melakukan semua kegiatan pembelajaran melalui sistem online. Cara ini sangat cocok untuk pelajar yang berada di zona merah.

3. Metode offline merupakan model pembelajaran yang dilakukan di luar jaringan. Dalam artian, pembelajaran yang satu ini dilakukan secara tatap muka dengan memperhatikan zonasi dan protokol kesehatan yang berlaku. Metode ini sangat cocok untuk siswa di zona kuning atau hijau, terutama dengan protokol ketat normal yang baru.

4. Kunjungan rumah merupakan salah satu pilihan dalam metode pembelajaran selama pandemi ini. Metode ini mirip dengan kegiatan belajar mengajar yang disampaikan selama homeschooling. Jadi, guru melakukan kunjungan rumah ke rumah siswa dalam waktu tertentu. Dengan demikian materi yang diberikan kepada siswa dapat tersampaikan dengan baik karena materi pelajaran dan tugas dilaksanakan dengan baik dibawah bimbingan guru.

5. Blended learning merupakan metode yang menggunakan dua pendekatan sekaligus. Dalam arti tertentu, metode ini menggunakan sistem online serta tatap muka melalui video konferensi. Jadi, meski siswa dan guru melakukan pembelajaran jarak jauh, mereka tetap bisa saling berinteraksi. Metode ini berguna untuk meningkatkan kemampuan kognitif siswa. 
6. Belajar melalui radio adalah inovasi pembelajaran selama pandemi Covid-19.

Mengingat wabah Covid-19 yang belum diketahui pasti kapan akan berakhir, pemerintah melalui Kementerian Pendidikan menyarankan metode pembelajaran di atas menjadi pilihan bagi siswa, guru, dan sekolah untuk melanjutkan kegiatan belajar mengajar. Bahkan metode tersebut akan digunakan sebagai dasar dalam tulisan ini untuk menganalisis situasi dan kebutuhan siswa di daerah terpencil.

\section{Kebutuhan Model Pembelajaran Siswa Daerah 3T di Maluku}

Maka dari itu, pembelajaran online sebagai solusi efektif pembelajaran di rumah untuk memutus rantai penyebaran Covid-19, jarak fisik (menjaga jarak aman) juga menjadi pertimbangan untuk memilih pembelajaran ini. Kerja sama yang baik antara guru, siswa, orang tua, dan sekolah merupakan faktor penentu pembelajaran online yang lebih efektif. Dari hasil analisis data tersebut, peneliti merancang model pembelajaran yang sesuai untuk sekolahsekolah di daerah terpencil seperti pada gambar berikut.

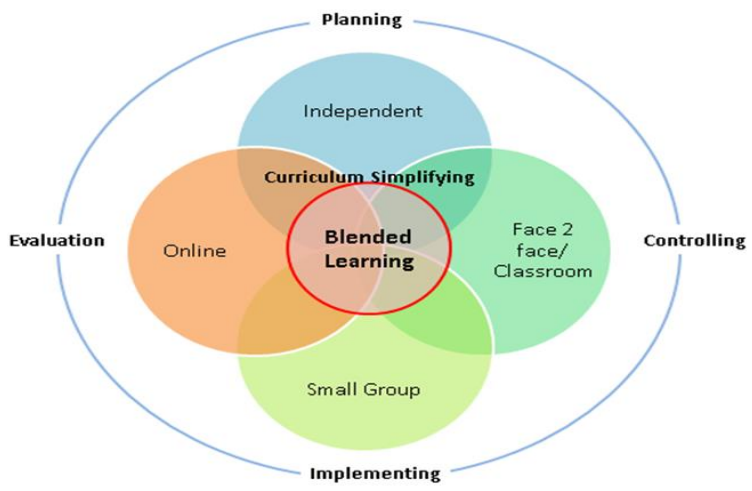

Gambar 3: Model Multi-blended Learning untuk Daerah Terpencil 
Gambar di atas menunjukkan beberapa pendekatan dan metode, sehingga dinamakan multi blended learning, cocok untuk sekolah di daerah terpencil setelah penyederhanaan kurikulum. Proses pembelajaran diawali dengan perencanaan pembuatan RPP yang mengikuti setiap pertemuan yang akan diadakan dan materi apa saja yang diajarkan secara tatap muka dan online, serta kegiatan pembelajaran mana yang akan diajarkan dengan menggunakan kelompok kecil dimana siswa berkumpul secara kecil-kecilan. kelompok berdasarkan lokasi atau daerah tempat tinggalnya kemudian guru akan berkunjung ke rumah untuk melaksanakan pembelajaran. Begitu pula guru menentukan materi mana yang harus diberikan kepada siswa untuk belajar mandiri di rumah sendiri. Guru menyusun porsi tiap tahapan, tetapi yang terpenting dari semua tahapan adalah guru selalu mengontrol apa yang telah direncanakan dan dilaksanakan dalam pembelajaran serta mengevaluasi semua tahapan.

Dengan menerapkan pembelajaran multi blended ini, guru dapat melaksanakan pembelajaran yang beragam dan memenuhi karakteristik pembelajaran siswa yang berbeda. Misalnya siswa yang enggan berdiskusi di kelas mungkin lebih aktif berdiskusi menulis secara mandiri atau dengan sesama siswa dalam pembelajaran kelompok kecil. Hasil penelitian menunjukkan bahwa blended learning lebih efektif daripada pembelajaran tatap muka dan e-learning. Tidak semua orang berani menyampaikan pendapatnya secara tidak langsung di tempat umum seperti di kelas. Beberapa siswa memiliki banyak ide tetapi tidak cukup berani untuk menunjukkannya. Dengan blended learning ini, siswa yang lebih introvert akan lebih aktif.

Selain itu pembelajaran terjadi secara mandiri dan konvensional yang keduanya memiliki kelebihan yang 
dapat saling melengkapi. Pembelajaran lebih efektif dan efisien serta dapat meningkatkan aksesibilitas. Dengan adanya blended learning, peserta belajar lebih cepat dalam mengakses materi pembelajaran. Proses belajar mengajar dilakukan secara tatap muka dan meningkatkan waktu belajar dengan memanfaatkan teknologi dunia maya. Sederhanakan dan percepat proses komunikasi nonstop antara guru dan siswa. Kegiatan diskusi berlangsung secara online/offline dan berlangsung di luar jam pelajaran, dan kegiatan diskusi berlangsung baik antara siswa dengan guru maupun antar siswa itu sendiri. Guru dapat mengatur dan mengontrol pembelajaran yang dilaksanakan oleh siswa di luar jam pelajaran siswa. Guru dapat meminta siswa untuk meninjau materi pelajaran sebelum pembelajaran tatap muka berlangsung dengan menyiapkan tugas pendukung. Target pencapaian bahan ajar dapat tercapai sesuai target yang telah ditetapkan.

Berdasarkan temuan dan pembahasan di atas, dapat disimpulkan bahwa kebutuhan siswa di sekolah-sekolah yang berada di daerah terpencil di Kabupaten Buru memerlukan blended learning dengan memadukan offline dan online. Mereka juga membutuhkan penyederhanaan kurikulum dan penyesuaian dengan materi inti berdasarkan silabus yang ada di sekolah. Materi pembelajaran hendaknya dimulai dengan materi yang mudah dan ada disekitar siswa. Untuk menunjang keberhasilan pembelajaran di daerah terpencil, desain yang tepat untuk diterapkan adalah multi blended learning, yaitu dengan memadukan beberapa metode dan pendekatan dalam pembelajaran yaitu tatap muka, online, belajar mandiri, dan kelompok kecil starting. dengan perencanaan yang matang oleh guru dengan mengontrol pelaksanaan setiap tahapan 
yang dilakukan dan mengevaluasi semua tahapan yang telah dilalui. 


\section{Daftar Pustaka}

Allo, M. D. G. (2020). Is online learning good during Covid19 Pandemic? The case of EFL learners. Jurnal Sinestesia, 10(1), 1-10.

Astini, N. K. S. (2020). Pemanfaatan teknologi informasi dalam pembelajaran tingkat sekolah dasar pada masa pandemi covid-19. Lampuhyang, 11(2), 13-25.

Atsani, K. L. G. M. Z. (2020). Transformasi media pembelajaran pada masa Pandemi COVID-19. AlHikmah: Jurnal Studi Islam, 1(1), 82-93.

Ayuni, D., Marini, T., Fauziddin, M., \& Pahrul, Y. (2020). Kesiapan Guru TK Menghadapi Pembelajaran Daring Masa Pandemi Covid-19. Jurnal Obsesi: Jurnal Pendidikan Anak Usia Dini, 5(1), 414-421.

Bin Tahir, S. Z. (2017). Multilingual teaching and learning at Pesantren Schools in Indonesia. Asian EFL Journal, 89, 74-94.

Bin-Tahir, S. Z., Suriaman, A., \& Rinantanti, Y. (2019). Designing English Syllabus for Multilingual Students at Pesantren Schools. Asian EFL Journal, 23(3.3), 5-27..

Murphy, S. L. (2015). How do we teach them to read if they can't pay attention? Change in literacy teaching practice through collaborative learning. Language and Literacy, 17(1), 83-105.

Thiagarajan, S., Semmel, D. S \& Semmel, M. I. 1974. Instructional Development for Training Teachers of Expectional Children. Minneapolis, Minnesota: Leadership Training Institute/Special Education, University of Minnesota.

Trianto (2010). Model Pembelajaran Terpadu. Jakarta: PT Bumi Aksara. 


\title{
GAMBARAN SOFT SKILL MAHASISWA DI TENGAH PANDEMI COVID 19
}

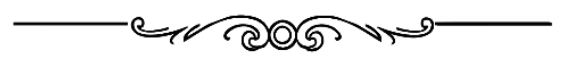

\author{
Katharina E.P Korohama, S.Pd., M.Pd 13 \\ Universitas Nusa Cendana
}

"Pentingnya belajar dan mengasah soft skill bagi mahasiswa, salah satunya adalah agar dapat menjadi output berkualitas ketika lulus dan siap terjun ke masyarakat."

$\mathrm{M}$ embayangkan tentang apa yang dikatakan oleh Henry Ford, seorang produsen mobil ternama dari Amerika Serikat, bahwa satu-satunya keamanan nyata yang akan dimiliki seseorang di dunia ini adalah simpanan pengetahuan, pengalaman dan keahlian, sama dengan melihat perkembangan dan arah kemajuan dunia saat ini yang banyak membutuhkan tenaga ahli serta kompeten dalam bidang masing-masing. Betapa pentingnya sebuah Pendidikan yang diimbangi dengan pengalaman untuk mempertajam keahlian seseorang bagi kemajuan sebuah peradaban. Melalui Pendidikan pada Perguruan Tinggi, diharapkan mampu menjawab akan tantangan dan kebutuhan ini dengan mencetak SDM berkualitas, yang tidak hanya cerdas dalam akademik tapi juga non akademik seperti soft skill yang memadai. Kata orang saat ini, orang

13Katharina Edeltrudis Perada Korohama, lahir di Kupang, NTT 23 Juni 1991. Meraih gelar Sarjana Pendidikan pada program Studi Bimbingan Konseling, Universitas Nusa Cendana Kupang pada tahun 2013, lalu melanjutkan pendidikan Magister di Universitas Negeri Semarang pada program Studi Bimbingan Konseling, lulus di tahun 2016. Saat ini berprofesi sebagai Dosen pada Universitas Nusa Cendana, Kupang, NTT. 
pintar saja tidak cukup untuk membuat kemajuan sebuah jaman, namun juga harus dibarengi dengan kenyataan bahwa keahlian dan keterampilan turut berproses di dalamnya. Pandangan akan hal ini juga diangkat dalam buku Emotional Intelligence and School Success karangan Joseph Zins (2001) bahwa factor resiko kegagalan anak di sekolah justru bersumber dari karakter. Karakter yang membantu untuk meraih keberhasilan adalah rasa percaya diri, kemampuan bekerja sama, kemampuan bergaul, kemampuan berkonsentrasi, rasa empati dan kemampuan berkomunikasi.

Kemampuan-kemampuan ini selain telah dipelajari dalam keluarga dan lingkungan pergaulan, perlu juga untuk diperdalam dan diasah dalam dunia pendidikan, secara khusus oleh Pendidikan Tinggi yang nantinya akan mencetak tenaga atau sumber daya yang bisa diserap oleh lapangan pekerjaan. Dalam aktivitas perkuliahan, kegiatan ekstrakurikuler kampus atau dalam aktivitas kampus lainnya, terselip ilmu tak kasat mata yang bersifat melatih setiap hari dan setiap saat tentang apa yang dinamakan soft skill ini. Keahlian dan keterampilan ini juga menjadi bagian dalam struktur penilaian yang tercermin melalui perilaku mahasiswa dalam kesehariannya. Pembinaan ini bertujuan untuk menumbuhkembangkan perilaku baru yang lebih efektif guna mendukung kecakapan hidup selama dan setelah menempuh pendidikan.

\section{Urgensi Soft skill}

Soft skill dalam pemahamannya menurut Elfrindi dkk (2011) merupakan keterampilan hidup yang sangat menentukan keberhasilan seseorang, yang wujudnya antara lain berupa kerja keras, eksekutor, jujur, visioner, dan disiplin. Pengertian ini memiliki pemahaman bahwa penentu keberhasilan seseorang tidak saja tentang 
bagaimana kecerdasannya dalam mengelola ilmu pengetahuan namun juga tentang bagaimana perilaku positif dan produktif turut berkembang di dalamnya. Sedangkan menurut Kaipa \& Milus (2005) soft skill adalah kunci untuk meraih kesuksesan, termasuk di dalamnya kepemimpinan, pengambilan keputusan, penyelesaian konflik, komunikasi, kreativitas, kemampuan presentasi, kerendahan hati dan kepercayaan diri, kecerdasan emosional, integritas, komitmen, dan Kerjasama. Di sisi lain, nada yang sama juga terungkap dari LaFrance (2016), yang mendefinisikan soft skill sebagai "personal and interpersonal behaviour that develop and maximize human performance (e.g. confidence, flexibility, honesty, and integrity)". Melihat kembali beberapa pengertian ini, dapat ditajamkan beberapa poin bahwa soft skill adalah salah satu kompetensi yang perlu dimiliki oleh individu, secara khusus seorang pelajar/mahasiswa dengan indikator yang dikembangkan adalah kejujuran, problem solving, kreativitas, kepemimpinan, kepercayaan dan lainnya, poin kedua bahwa soft skill dapat dilatih dan dikembangkan dalam kehidupan sehari-hari, poin ketiga, soft skill adalah perilaku-perilaku positif yang ditampilkan berkat hasil pengelolaan IQ dan EQ.

Pentingnya belajar dan mengasah soft skill bagi mahasiswa, salah satunya adalah agar dapat menjadi output berkualitas ketika lulus dan siap terjun ke masyarakat, yang tidak saja hanya dibuktikan dengan kuantitas, dalam hal ini IPK yang tinggi tapi juga dengan etos kerja serta kecerdasan emosional yang baik. Masyarakat masa kini sudah sangat pintar dan jeli di dalam menilai kualitas lulusan Perguruan Tinggi.

Mutu lulusan Perguruan Tinggi yang diharapkan oleh dunia kerja saat ini menurut hasil survey yang dilakukan 
oleh NACE USA mengungkapkan bahwa soft skill sebagai keterampilan lunak, menjadi perhatian yang cukup besar bagi dunia kerja saat ini. Data yang disampaikan menyebutkan kemampuan komunikasi, kejujuran/integritas, kemampuan kerjasama, kemampuan interpersonal, etos kerja yang baik, memiliki motivasi/inisiatif, mampu beradaptasi, kemampuan analitikal, kemampuan computer dan kemampuan berorganisasi berada pada peringkat 10 besar indikator penting dalam mutu lulusan yang berkualitas.

Lantas bagaimana dengan potret lulusan di Indonesia? Organization for Economic Co-operation Development (OECD, 2013) melaporkan bahwa lulusan Perguruan Tinggi di Indonesia gagal mengimbangi keinginan pasar, dikarenakan sulit menemukan orang yang bisa berpikir kritis, punya pengalaman dalam bekerja dan sulitnya beradaptasi dengan lingkungan kerja. Kenyataan seperti ini perlu dijadikan warning baik bagi Perguruan Tinggi, maupun secara khusus bagi seluruh pendidik agar mampu merancang pembelajaran, suasana dan iklim belajar yang konstruktif dan ruang pengembangan diri bagi mahasiswa.

\section{Soft skill di Masa Pandemi Covid 19}

Di masa pandemi Covid 19 yang telah berlangsung setahun lebih di Indonesia, memaksa dunia pendidikan untuk tetap menyelenggarakan kegiatan belajar dengan memanfaatkan teknologi dan internet sebagai sarana belajar. Kebijakan ini dilakukan ke seluruh Indonesia dan ke semua jenjang Pendidikan. Dengan demikian usaha belajar tetap berjalan dengan modifikasi tertentu pada rancangan pembelajarannya. Berbicara tentang perubahan metode pembelajaran dan jabaran panjang tentang soft skill, sepertinya keadaan ini memberi ruang untuk soft skill itu bisa lebih subur bertumbuh dan berkembang, mengingat 
jika dilihat, proses pembelajaran yang dilakukan tidak mengharuskan mahasiswa bertemu secara langsung namun melalui media, tugas dan perkuliahan menjadi lebih berbeda sebab belajar mandiri menjadi ciri keutamaan, serta tingkat penguasaan IT (aplikasi belajar, pola mengerjakan tugas yang bervariasi dengan memanfaatkan aplikasi sebagai media pengembang) menjadi beberapa ciri yang terlihat.

Tantangan baru di era baru ini pelan tetapi pasti harus dijalani. Oleh karenanya karakter/soft skill seseorang yang mampu beradaptasi, mampu mengendalikan dan mengontrol diri, memiliki motivasi yang tinggi, disiplin dan kreatif sangat diperlukan dalam upaya mengontrol penyebaran virus serta meningkatkan kualitas mahasiswa di Perguruan Tinggi itu sendiri.

Beberapa penelitian menunjukan bahwa potret soft skill mahasiswa di tengah pandemic mengalami tren yang bervariasi. Agustina (2020) dalam penelitiannya menemukan bahwa remaja mengalami perkembangan dalam penggunaan media digital untuk tujuan berkomunikasi, bahkan banyak aplikasi pengirim pesan yang sering mereka pakai yang disesuaikan dengan bentuk komunikasi, tetapi penelitian ini juga menemukan bahwa meskipun frekuensi komunikasi dengan media digital meningkat, tetapi remaja tetap membutuhkan komunikasi tatap muka. Karakter berikut yang diteliti oleh Gultom (2020) pada mahasiswa program studi pendidikan Profesi Ners menyebutkan bahwa kemampuan kerja sama antar mahasiswa yang semakin rendah, kemandirian dan motivasi mahasiswa juga menurun, namun pengembangan karakter yang bernilai positif juga terjadi diantaranya mahasiswa belajar disiplin waktu pada saat mengumpulkan 
tugas dan komunikasi antar dosen dan mahasiswa meningkat.

Dari gambaran ini, bisa terlihat bahwa masa pandemi ini membawa banyak warna baru dan perubahan baik yang bersifat maju, mundur bahkan berhenti di tempat. Namun begitu, selain mahasiswa menjadi agen untuk perubahan diri dan orang lain, masa pandemic juga menjadi kesempatan bagi orang tua atau keluarga sebagai unit terdekatnya ketika harus belajar daring, untuk membantu menanamkan nilai karakter yang baik guna mendorong keberhasilan study, membangun karakter baru seperti disiplin, menumbuhkan keimanan pada Tuhan, mendorong kerja sama dan komunikasi yang optimal. Sedangkan pendidik dan Lembaga Pendidikan memfasilitasi dengan inovasi kurikulum, inovasi pembelajaran yang menyediakan kesempatan bagi mahasiswa untuk menggunakan teknologi sebagai ladang ilmu dan ruang ekspresi dan mendorong mahasiswa di dalam keikutsertaannya pada program Merdeka Belajar yang akan mendorong mahasiswa pada pengalaman belajar yang sesungguhnya sehingga memungkinkan tercapainya harapan semua orang akan kemajuan generasi dan Indonesia. 


\section{Daftar Pustaka}

Agustina, L. (2020). POLA KOMUNIKASI REMAJA GENERASI Z DI MASA PANDEMI COVID-19. voxpop, 2(2), 3645.

Elfindri, et al. 2010. Soft skills untuk Pendidik. t.k.: Baduose Media

Gultom, R. F. N., \& Tambunan, E. H. (2021). Pengalaman Mahasiswa Program Studi Pendidikan Ners Dalam Pembelajaran Daring Di Masa Pandemi Covid-19. Nursing Update: Jurnal Ilmiah Ilmu Keperawatan PISSN: 2085-5931 e-ISSN: 2623-2871, 12(1), 12-21.

Kaipa,P \& Milus, T. 2005. Soft skills are Smart Skills. http://www.kaipagroup.com

LaFrance, Aricia E. Helping Students Cultivate Soft skills.

Diakses pada 9 Mei 2021 pukul 22.13 Wita, dari

http://www.ncda.org/aws/NCDA/pt/sd/news_arti cle/7010/_PARENT/layout_details_cc/false

Republika, Kemenristekdikti dorong PT tingkatkan Akreditas, Artikel, http://www. Republika.com. diakses tanggal 9 Mei 2021, pukul 22.28 Wita.

Zins, Joseph etc. 2001. Emotional Intelligence and School Success. Dikutip dari Kompas.com. Diakses hari Rabu, 5 Mei 2021, pukul 14.35 Wita. 


\title{
POTRET PENDIDIKAN NON FORMAL DALAM BINGKAI PANDEMI COVID-19
}

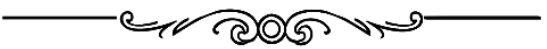 \\ Nirwaning Makleat, S.Si.,M.Pd14 \\ Universitas Nusa Cendana
}

"Penerapan proses Belajar Dari Rumah (BDR) selama masa pandemi covid-19 seolah menjadi "titik henti" sejenak yang menyadarkan bahwa pendidikan tidak hanya dapat dilakukan di sekolah."

$\mathrm{U}$ ndang-undang No. 20 Tahun 2003 Pasal 1 ayat 2 tentang Sistem Pendidikan Nasional memberi jawab kebijakan bangsa Indonesia atas pertanyaan "apa itu pendidikan non formal?". Pada prinsipnya pendidikan non formal berfungsi sebagai pengganti, penambah dan pelengkap pendidikan formal (UU Sisdiknas, 2004:23). "Tonggak" utama kebijakan ini selanjutkan melahirkan berbagai istilah, seperti pendidikan luar sekolah, pendidikan masyarakat dan istilah-istilah lainnya yang justru menyiratkan betapa luasnya ranah kajian pendidikan non formal. Lantas apa itu pendidikan non formal? Bagaimana bisa seseorang dapat mengenyam pendidikan di luar jalur pendidikan formal? Apa kontribusi konkret pendidikan non formal bagi kehidupan manusia? Begitu

14Penulis lahir di Soe, 03 November 1986, penulis merupakan Dosen Universitas Nusa Cendana Program Studi Pendidikan Luar Sekolah, penulis menyelesaikan gelar Sarjana Sains Theologia di Universitas Kristen Duta Wacana (2009) sedangkan gelar Magister Pendidikan diselesaikan di Universitas Negeri Yogyakarta Program Studi Pendidikan Luar Sekolah (2012) 
banyak pertanyaan mengisyaratkan bahwa masyarakat belum sepenuhnya memahami keberadaan pendidikan non formal. Pertanyaan-pertanyaan itu terus mengusik hingga muncul pandemi covid-19 yang mendorong penulis untuk mencoba melukiskan potret keberadaan pendidikan non formal dalam bingkai pandemi ini.

Dunia pendidikan di Indonesia turut merasakan dampak tingginya lonjakan kasus covid-19. Pemerintah, dalam hal ini Menteri Pendidikan dan Kebudayaan mengeluarkan Surat Edaran No.4 Tahun 2020 tentang Pelaksanaan Kebijakan Pendidikan dalam Masa Darurat Penyebaran Corona Virus Disease (Covid-19). Proses Belajar Dari Rumah (BDR) dicetuskan sebagai salah satu bentuk keikutsertaan dunia pendidikan dalam rangka memutus mata rantai penyebaran virus covid-19. Adapun diungkapkan dalam Surat Edaran tersebut bahwa proses Belajar Dari Rumah dapat difokuskan pada pendidikan kecakapan hidup, antara lain mengenai pandemi covid-19.

Istilah pendidikan kecakapan hidup bukanlah istilah yang baru dalam dunia pendidikan non formal. Kecakapan hidup (life skills) merupakan sebuah kecakapan yang dimiliki oleh seseorang untuk mau dan berani menghadapi problema hidup dan penghidupan secara wajar tanpa merasa tertekan, kemudian secara proaktif dan kreatif mencari serta menemukan solusi hingga pada akhirnya mampu mengatasi problema tersebut (Ditjen PLSP, 2004). Secara konseptual, indikator pendidikan kecakapan hidup (life skills) mencakup 1) kecakapan diri sendiri (self awarness) atau yang sering disebut kemampuan personal (personal skills); 2) kecakapan berpikir rasional (thinking skills) atau kecakapan akademik (academic skills); 3) kecakapan sosial (social skills) dan 4) kecakapan vokasional (vocational skills) atau yang sering disebut keterampilan 
kejuruan yakni keterampilan yang dikaitkan dengan bidang pekerjaan tertentu yang bersifat spesifik (spesific skills) atau keterampilan teknis (technical skills) (Ditjen PLS, 2003).

Dalam konteks pendidikan non formal, istilah pendidikan kecakapan hidup memiliki makna yang lebih luas dari sekedar sebuah keterampilan untuk bekerja. Pendidikan kecakapan hidup tidak hanya berbicara mengenai pendidikan yang terjadi dalam "tembok" ruang kelas yang teoritis tetapi yang mampu menyentuh langsung konteks kehidupan real setiap individu. Pada prinsipnya, pendidikan berbicara mengenai proses belajar untuk mengetahui (learning to know), belajar untuk melakukan (learning to do), belajar untuk hidup bersama (learning to live together) dan belajar untuk menjadi seseorang (learning to be) (Sindhunata, 2002:116). Pendidikan tidak hanya berbicara mengenai bagaimana seseorang dapat belajar untuk mengetahui sesuatu dan melakukan sesuatu namun lebih dari itu, bagaimana seseorang juga belajar untuk hidup bersama dan menjadi sesuatu yang dapat memberi makna bagi kehidupan bersama. Pendidikan seharusnya mampu membuat seseorang memahami dan mengembangkan potensi dirinya sendiri, mampu beradaptasi dan berinteraksi dalam konteks sosial, mampu berpikir rasional, kritis dan kreatif dalam mengambil keputusan serta menyelesaikan berbagai problema hidup.

Penerapan proses Belajar Dari Rumah (BDR) selama masa pandemi covid-19 seolah menjadi "titik henti" sejenak yang menyadarkan bahwa pendidikan tidak hanya dapat dilakukan di sekolah. Belajar tidak hanya berbicara tentang seorang guru yang berdiri memegang buku di depan kelas untuk mengajar murid-murid. Belajar merupakan sebuah proses memaknai kehidupan, baik secara individual 
maupun komunal. Proses pemaknaan ini dapat terjadi di mana saja dan kapan saja selama seseorang hidup. Dalam dunia pendidikan non formal, proses pembelajaran tidak hanya terjadi secara formal pada usia tertentu tetapi lebih dari itu, pembelajaran merupakan sebuah proses yang terjadi sepanjang manusia itu hidup atau yang lebih dikenal dengan istilah pendidikan sepanjang hayat (life long education) (Oong Komar, 2006:259). Selama manusia hidup, selama itu pula proses pembelajaran terus terjadi dalam diri manusia dan pengalaman hiduplah yang menjadi guru sekaligus sumber belajar yang kaya.

Pandemi covid-19 seolah membuktikan bahwa Sang Kuasa menganugerahkan kehidupan beserta semua problemanya untuk menuntun manusia terus menerus belajar memaknai dan mensyukuri kehidupan itu sendiri. Ketika proses pembelajaran secara tiba-tiba harus dilakukan dari rumah maka orang tua mulai belajar dari berbagai pengalaman hidupnya untuk mampu menjadi guru yang dapat menuntun proses belajar anak. Sistem pembelajaran tatap muka secara langsung (offline) yang kini berubah menjadi online turut menyentak banyak pihak untuk terus belajar terbiasa menggunakan berbagai media komunikasi online yang belum pernah digunakan sebelumnya. Relasi sosial yang sebelumnya terjalin lekat, kini berubah dan menuntut setiap individu untuk tetap belajar menjadi makhluk sosial yang menjalin relasi dengan tetap menggunakan masker, tidak saling berjabat tangan dan tetap menjaga jarak.

Pada akhirnya, ketika kehidupan dan segala problemannya telah menjadi sumber belajar bagi manusia maka haruskah pendidikan terus "dipenjara" dalam konsep berpikir seluas ruang kelas? Kini saatnya pendidikan dibebaskan dari "kotak sempit" pemikiran manusia. 
Manusia hidup untuk belajar dan pendidikan akan terus membuka "ribuan tirai" bagi setiap individu untuk terus belajar di mana saja dengan cara-cara yang kreatif sepanjang manusia itu hidup dan terus menikmati anugerah kehidupan. 


\section{Daftar Pustaka}

Ditjen PLS. 2003. Program Life Skills Melalui Pendekatan Broad Based Education (BBE). Jakarta: Direktorat Tenaga Teknis Depdiknas

Ditjen PLSP. 2004. Pedoman Penyelenggaraan Program Kecakapan Hidup (Life Skills) Pendidikan Non Formal. Jakarta: Ditjen PLSP

Komar Oong. 2006. Filsafat Pendidikan Non Formal. Bandung: Pustaka Setia

Pusdiklat Kemdikbud. 2020. Surat Edaran Mendikbud No.4 Tahun 2020 Tentang Pelaksanaan Kebijakan Pendidikan Dalam Masa Darurat Penyebaran Corona Virus Disease (Covid-19). Pusdiklat Kementerian Pendidikan dan Kebudayaan. Https://Pusdiklat.Kemdikbud.go.id.

Sindhinata. 2002. Menggagas Paradigma Baru Pendidikan, Demokratisasi, Otonomi, Civil Society, Globalisasi. Yogyakarta: Kanisius

Undang-undang Sistem Pendidikan Nasional No.20 Tahun 2003. Jakarta: Depdiknas 


\title{
CORONA VIRUS DISEASE DALAM EVOLUSI PENDIDIKAN DI NUSA TENGGARA TIMUR
}

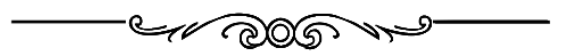

\author{
Melifera Yani Makleat, S.Si.,M.Si' ${ }^{15}$ \\ Sekolah Tinggi Keguruan dan Ilmu Pendidikan (STKIP) \\ Soe
}

\begin{abstract}
"Pandemi corona virus disease seolah mengubah pola interaksi dalam proses pembelajaran yang dahulu terjadi di

dalam kelas kini menjadi interaksi yang terbatas dalam media online."
\end{abstract}

$\mathrm{D}$ ewasa ini dunia dikejutkan dengan merebaknya pandemi virus covid-19 yang menyebar ke penjuru dunia tak terkecuali Indonesia. Organisasi Kesehatan Dunia (World Health Organization) memberi nama virus baru tersebut Severe Acute Respiratory Syndrome Coronavirus2(SARS-CoV-2) dan nama penyakit ini disebut Coronavirus Disease 2019 (Covid-19) (Yuliana, 2020). Pada dasarnya virus ini menyerang saluran pernapasan dan menginfeksi paru-paru dengan masa inkubasi 14 hari. Gejala umum bagi orang yang terinfeksi corona virus disease antara lain demam, batuk dan pilek. Wabah corona virus ini tidak hanya menimbulkan ketakutan pada masyarakat tetapi juga

15Penulis lahir di Soe, 06 Maret 1990, penulis merupakan Dosen Sekolah Tinggi Keguruan dan Ilmu Pendidikan (STKIP) Soe Program Studi Pendidikan Biologi, penulis menyelesaikan gelar Sarjana Sains di Universitas Nusa Cendana (2013) sedangkan gelar Magister Sains diselesaikan di Universitas Kristen Satya Wacana Program Studi Biologi (2018) 
menyebabkan gangguan dan ketidakstabilan pada semua sektor kehidupan, tidak terkecuali sektor pendidikan.

Dalam rangka menekan angka penyebaran corona virus disease maka Kementerian Pendidikan dan Kebudayaan Republik Indonesia menerbitkan Surat Edaran Nomor 4 tahun 2020 yang mengatur tentang pelaksanaan pendidikan dalam menghadapi situasi darurat penyebaran corona virus disease. Pembelajaran yang awalnya dilakukan dengan metode tatap muka terpaksa harus dilakukan secara online atau daring. Sanggupkah Nusa Tenggara Timur sebagai salah satu daerah tertinggal di Indonesia mampu berdamai dengan sistem pembelajaran online ataukah sistem pembelajaran ini justru menjadi musuh terbesar dalam rangka penyelenggaraan pendidikan?

Pada prinsipnya proses pembelajaran merupakan proses transfer ilmu dua arah, antara guru sebagai pemberi informasi dan siswa sebagai penerima informasi. Pernyataan ini menyiratkan proses pembelajaran ibarat proses ekologi yang didalamnya terdapat hubungan timbal balik antara guru dan siswa. Sebagaimana dalam proses ekologi, proses pembelajaran juga membutuhkan adaptasi. Dalam konteks pembelajaran, proses adaptasi menekankan bagaimana seseorang mampu mengatasi tekanan lingkungan sekitarnya untuk tetap bertahan hidup.

Pandemi corona virus disease seolah mengubah pola interaksi dalam proses pembelajaran yang dahulu terjadi di dalam kelas kini menjadi interaksi yang terbatas dalam media online. Pola interaksi ini jelas akan berbeda antara satu wilayah dengan wilayah lainnya. Pada kenyataannya, dalam konteks Nusa Tenggara Timur, model pembelajaran online sangat bergantung pada ketersediaan gadget, kestabilan jaringan dan kemampuan dalam mengoperasikan media online. 
Nusa Tenggara Timur merupakan satu dari lima Provinsi dengan jumlah penduduk miskin terbanyak di Indonesia (BPS NTT, 2020). Kenyataan ini jelas tidak memungkinkan semua orang, khususnya warga belajar di Nusa Tenggara Timur untuk memiliki gadget. Letak geografis di bagian tengah Indonesia juga menjadi salah satu penghalang kestabilan jaringan, termasuk keterbatasan keterampilan dalam mengoperasikan berbagai jenis media online. Dalam situasi seperti ini mungkinkah dunia pendidikan di Nusa Tenggara Timur dapat terus menciptakan interaksi pembelajaran yang efektif?

Kehadiran corona virus disease di Nusa Tenggara Timur ibarat dua sisi mata uang. Pada satu sisi, apabila masyarakat dapat beradaptasi dengan perubahan ini maka pendidikan akan tetap berlanjut. Pada sisi lain, apabila masyarakat tidak dapat beradaptasi maka pendidikan hanya akan menjadi wacana semata. Dalam menyikapi situasi ini, masyarakat Nusa Tenggara Timur dituntut untuk mampu mencari berbagai peluang kreatif untuk dapat melihat kemungkinan-kenungkinan lain yang dapat terjadi.

Selamanya corona virus disease akan menjadi lawan apabila masyarakat hanya berpatokan pada paradigma keilmuan secara harafiah bahwa virus ini dapat menular dengan cepat dan akan selalu berujung pada kematian. Padahal jika dilihat dengan cermat, sekalipun corona virus disease sudah menyerang saluran pernapasan dan menginfeksi paru-paru, virus ini masih membutuhkan waktu inkubasi kurang lebih 14 hari. Hal ini berarti bahwa dalam 14 hari sistem imun manusia perlu dijaga agar sanggup mematikan virus yang masuk tersebut. Secara singkat, pernyataan ini menunjukkan bahwa corona virus disease bukanlah lawan yang dapat melumpuhkan serta 
mematikan seluruh aktivitas dan potensi diri manusia. Sebaliknya corona virus disease adalah lawan yang perlu dihadapi dengan senjata imunitas tubuh yang kuat. Penerapan protokol kesehatan juga perlu dilakukan secara berkesinambungan guna melawan penyebaran virus ini.

Terlepas dari keberadaan corona virus disease yang merisaukan, hidup harus terus berlanjut. Mau atau tidak, mampu atau tidak mampu, manusia dituntut untuk berdamai dan hidup berdampingan dengan corona virus disease. Pemahaman ini penting sebagai bekal bagi manusia untuk masuk dalam era new normal. Konteks dunia Sains mengibaratkan era new normal seperti proses evolusi kehidupan. Pada prinsipnya, dalam evolusi terdapat proses seleksi alam dimana organisme yang mampu beradaptasi akan tetap hidup namun sebaliknya organisme yang tidak mampu beradaptasi akan punah. Sama halnya dengan corona virus disease saat ini. Apabila manusia mampu beradaptasi dalam era new normal maka manusia akan tetap bertahan hidup dan sebaliknya jika manusia tidak dapat beradaptasi maka manusia akan tetap terkungkung dalam ketakutan hingga pada akhirnya tidak dapat mengembangkan potensi diri.

Sanggupkah masyarakat Nusa Tenggara Timur lolos dari proses seleksi alam ini? Sanggupkah dunia pendidikan Nusa Tenggara Timur berdamai dengan perubahan ini? Apabila corona virus disease telah mampu mengubah kehidupan dunia maka corona virus disease juga akan mampu membuka ribuan kemungkinan kreatif bagi masyarakat Nusa Tenggara Timur untuk terus berevolusi. 


\section{Daftar Pustaka}

BPS NTT. 2020. Profil Kemiskinan di Propinsi NTT. https://ntt.bps.go.id

Campbell, N.A., Reece, J.B., Urry, L.A., Cain, M.L., Wasserman, S.A., Minorsky, P.V., et al. 2010. Biologi Edisi Kedelapan Jilid 3. Jakarta: Erlangga

Pusdiklat Kemdikbud. 2020. Surat Edaran Mendikbud No.4 Tahun 2020 Tentang Pelaksanaan Kebijakan Pendidikan Dalam Masa Darurat Penyebaran Corona Virus Disease (Covid-19). Pusdiklat Kementerian Pendidikan dan Kebudayaan. Https://Pusdiklat.Kemdikbud.go.id.

Yuliana. 2020. Corona Virus Disease (Covid-19); Sebuah Tinjauan Literatur. Wellness and Healthy Magazine. 2020 Feb; 2 (1): 187-192 


\section{DINAMIKA PEMBELAJARAN DI PSDKU ARU PADA MASA PANDEMI COVID-19}

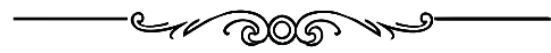

Corneli Gaite, M.Pd16

PSDKU Universitas Pattimu di Kabupaten Kepulauan Aru

"Salah satu keputusan pemerintah yang memberi dampak luas adalah kebijakan pada segmen pendidikan untuk tetap pada pembelajaran daring."

$\mathrm{P}$ endidikan adalah suatu sistem yang mampu membawa manusia pada perubahan yang lebih baik, dan untuk memanusiakan menjadi manusia, dalam artian Pendidikan mampu merubah setiap individu atau makluk hidup yang diciptakan oleh sang pencipta dalam hal manusia dengan akhlak yang mampu berpikir dengan akal atau pikiran sehingga dapat merubah mensen hidup yang membawa peruhana atau keuntungan bagi diri sendiri. Kata dari Pendidikan dalam bahasa inggris disebut education, dalam bahasa latin pendidikan disebut dengan educatum yang tersusun dari dua kata yaitu E dan Duco dimana kata E berarti sebuah perkembangan dari dalam ke luar atau dari sedikit banyak, sedangkan Duco berarti perkembangan atau sedang berkembang. Jadi, Secara Etimologi pengertian

16Penulis Lahir di Dobo, 25 September 1992, saat ini penulis merupakan dosen aktif Pendidikan Jasmani Olahraga dan Kesehatan (PJOK) pada Universitas Pattimura Program Studi di Luar Kampus Utama (PSDKU) di Kabupaten Kepulauan Aru. Pendidikan sarjana diselesaikan pada tahun 2015 dan magister pada tahun 2019 di Pasca Sarjana Negeri Malang. 
pendidikan adalah proses mengembangkan kemampuan diri sendiri dan kekuatan individu. Sedangkan menurut Kamus Bahasa Indonesia, pendidikan adalah proses pengubahan sikap dan tata laku seseorang atau kelompok orang dalam usaha mendewasakan manusia melalui upaya pengajaran dan pelatihan.

Pada masa era globalisasi 20-an saat ini diingatkan kembali pada masa akhir tahun 2019 yang menjadi catatan kehidupan bagi belahan bumi dengan suatau wabah penyakit yang di sebut atau dinamakan covid-19 yaitu wabah virus yang dengan cepat menyebar dari satu tubuh manusia ke yang lain lewat udara maupun bersentuhan. Maka pada setiap negara yang telah lebih dahulu diserang covid-19 menjadi model bagi negara lain dalam melakukan tindakan preventif penyebaran covid-19, meskipun terdapat perbedaan tatanan politik, sosial, budaya, ekonomi dan pendidikan pada setiap negara tersebut. Pemerintah Indonesia mengeluarkan sekmen atau aturan baru dari hulu ke hilir tersebut bersinergi untuk memutuskan mata rantai virus corona, salah satunya yaitu dengan tetap stay home, yang sangat berdampak pada kondisi internal dan eksternal di wilayah pemerintahan Indoneisa. Salah satu keputusan pemerintah yang memberi dampak luas adalah kebijakan pada segmen pendidikan untuk tetap pada pembelajaran daring.

Dengan putaran dunia hingga saat ini Pendidikan dituntut agar setiap manusia yang terlibat langsung dalam Pendidikan baik pada tingkat Pendidikan sekolah dasar (SD), sekolah menengah pertama (SMP), sekolah menengah atas (SMA), sampai pada perguruan tinggi, agar dapat mengenal atau menggunakan dunia online dengan baik dalam pembelajaran di masa pandemic covid-19. 
Indonesia dikenal dengan ciri khas seribu pulau dari berbagai tatanan budaya, Bahasa yang memiliki keunikan tersendiri dari negara lain. Dan di dalamnya yang menjadi faktor pendorong terbesar yaitu Pendidikan. Pada bagian timur Indonesia terdapat salah satu kepulauan yang berdekatan dengan Papua dan laut Afrika, yaitu Kabupaten Kepulauan Aru yang termasuk pada Provinsi Maluku. Kabupaten Kepulauan Aru memiliki 187 pulau dengan hanya 89 pulau yang berpenghuni. Lima pulau terbesar diantaranya Kola, Wokam, Kobror, Maekor, dan Tarangan. Luas total daratan adalah $6.426 \mathrm{~km} 2$ dengan luas lautan 7,6 kali luas daratan.

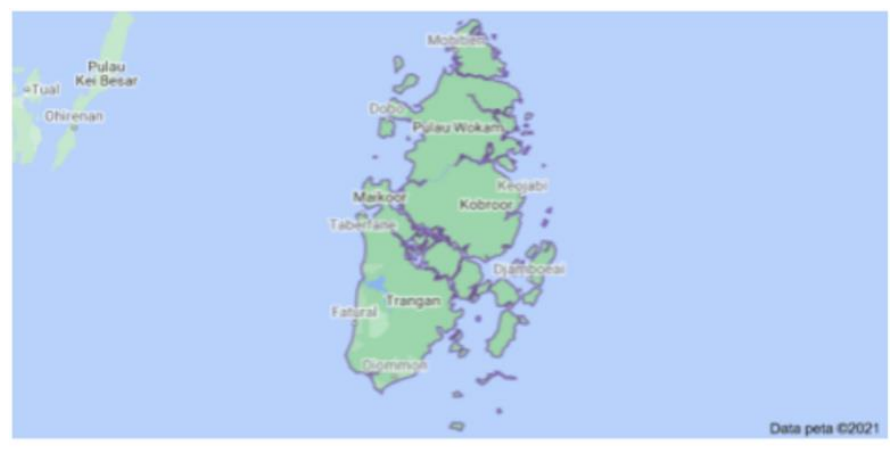

Gambar. 1. Peta Kabupaten Kepulauan Aru

Di kabupaten Kepulauan Aru telah berdiri suatu Lembaga Pendidikan yang baru yaitu kampus cabang dari Universitas Pattimura Ambon pada 14 April 2016 yang telah di buka dua cabang oleh Unpatti, yaitu PSDKU di Kabupaten Kepulauan Aru PSDKU di kabupaten MBD, dan telah disetujui oleh Menteri RISTEK DIKTI dan telah diserahkan mandat oleh Prof. Dr. Muhammad Nasir kepada rektor Unpatti Prof. Dr. M.J. Sapteno, S.H., M.Hum, disaksikan oleh Bupati Kepulauan Aru (dr. J. Gongga) dan Bupati Maluku Barat Daya (MBD) Drs. Barnabas Orno dan Dirjen Kelembagaan DIKTI, Dr. Patdono Suwignjo. 


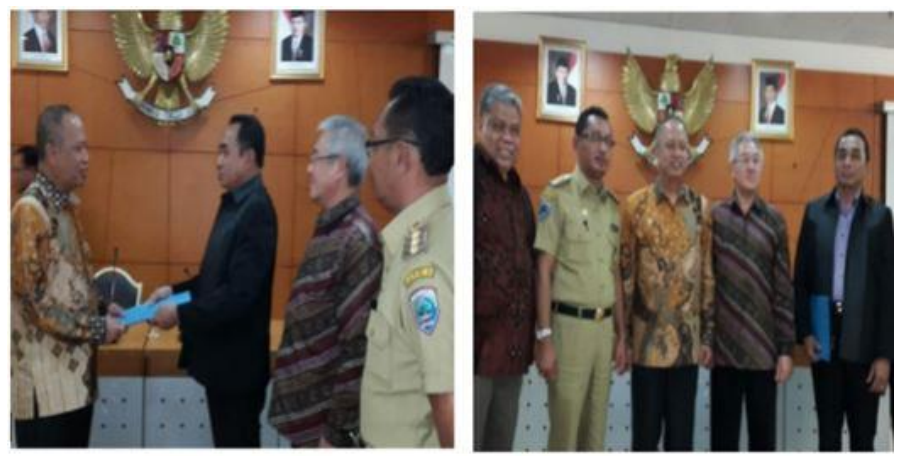

Gambar. 2. Penyerahan Mandat PDD-UNPATTI oleh Menteri RISTEK DIKTI

PSDKU Aru terdiri atas enam program studi yang terdiri dari program studi Hukum, program studi Akuntansi, program studi PGSD, program studi Pendidikan Olahraga, Program studi Matematika, dan juga program studi Bahasa Inggris. Dari jumlah data keseluruhan mahasiswa mulai dari tahun 2016-2021, sebanyak 1628 mahasiswa telah terdaftar di PSDKU Aru. Dengan status kampus yang baru berdiri selama kurang lebih 5 tahun dengan jumlah mahasiswa 1628 merupakan pencapaian yang perlu diapresiasi.

Jumlah mahasiswa mestilah sepadan dengan kualitas pendidikan, ketersediaan tenaga pendidik dan kependidikan yang berkualitas serta ketersediaan sarana dan prasarana yang memadai. Sebagai kampus yang baru berdiri, PSDKU Aru telah berbenah dalam penyiapan sarana prasarana pembelajaran yang sesuai standar yang ditetapkan. Selama masa pandemi Covid-19, PSDKU Aru telah menerapkan pembelajaran daring sesuai dengan instruksi dari Menteri Pendidikan dan kebudayaan. Hampir semua mata kuliah dibawakan secara online melalui kelaskelas virtual. 
Tak dapat dipungkiri bahwa terdapat berbagai kendala pada pelaksanaan pembelajaran online. Mahasiswa yang berasal dari keluarga ekonomi lemah mengalami kendala terkait ketersediaan handphone, laptop, smartphone maupun ketersedian paket data dan wifi di rumah. Kondisi ini tentu saja akan berdampak terhadap kualitas pembelajaran. Akan tetapi PSDKU kemudian memberikan solusi di tengah-tengah berbagai kendala yang muncul. Kampus memfasilitasi para mahasiswa dengan menyediakan ruang teleconference untuk dimanfaatkan oleh mahasiswa yang tidak memiliki smartphone dan laptop maupun yang terkendala dengan ketersediaan jaringan internet.
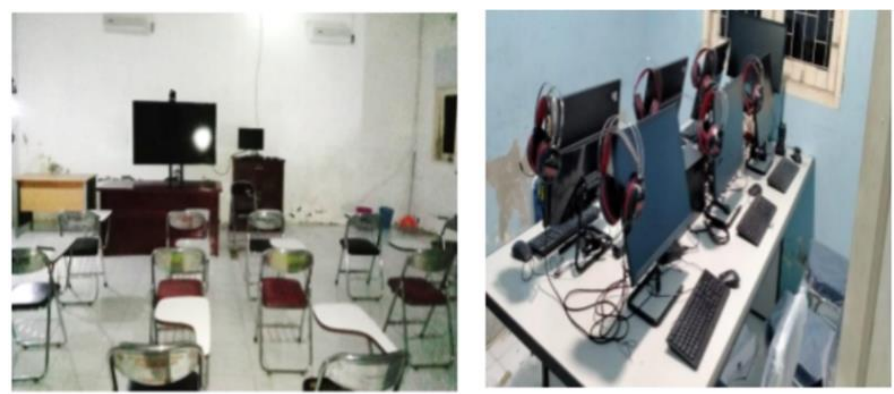

Gambar. 3. Ruangan Teleconverence dan Ruang Kontrol Kelas Teleconverence

Sebagai perguruan tinggi yang baru berproses kurang lebih lima tahun dengan berbagai kendala dan tantangan yang ada, sebenarnya memberikan peluang bagi setiap unsur yang ada di dalamnya untuk terus berbenah, untuk mewujudkan Pendidikan yang berkualitas demi mempersiapkan sumber daya manusia yang handal di kabupaten kepulauan Aru secara khusus dan Indonesia secara umum. 


\title{
DAMPAK PENDIDIKAN KEWIRAUSAHAAN PADA GELIAT USAHA TANAMAN HIAS DI MASA PANDEMI COVID-19
}

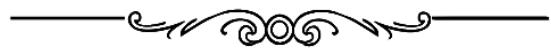

\author{
Sukarman Hadi Jaya Putra, S.Pd., M.Si17 \\ Universitas Nusa Nipa
}

\begin{abstract}
"Menjadi wirausahawan di bidang tanaman hias akan berjalan dengan baik jika orang tersebut memiliki pengetahuan yang baik di bidang tanaman."
\end{abstract}

Kemunculan corona virus disease 2019 atau yang kita pandemi yang berhasil merubah kondisi dunia. Virus yang hanya membutuhkan waktu 2 bulan sudah mampu menyebar dari daerah Wuhan China sampai ke seluruh penjuru dunia (Bwire \& Paulo, 2020). Sehingga pada tanggal 12 Maret 2020, badan Kesehatan dunia yaitu WHO (World Health Organization) menetapkan Covid-19 sebagai pandemi. Oleh karena itu banyak negara yang memberlakukan protokol Kesehatan yang sangat ketat dan pembatasan sosial berskala besar. Penerapan protokol Kesehatan dan aktivitas PSBB memberikan dampak terhadap lesunya perekonomian dunia.

17Penulis lahir di Sepolong, 31 Desember 1988, penulis merupakan Dosen Universitas Nusa Nipa dalam bidang ilmu Pendidikan Bilogi dan Biologi, penulis menyelesaikan gelar Sarjana Pendidikan IPA Biologi Institut Agama Islam Negeri Mataram yang sekarang berubah nama menjadi Universitas Islam Negeri Mataram (2012), gelar Master pada Biologi di Universitas Diponegoro (2015). 
Pandemic covid-19 berdampak pada berbagai sektor. Mulai dari sektor Pendidikan sampai pada sektor industri. hal tersebut mengakibatkan banyak tenaga kerja yang mengalami pemutusan hubungan kerja (PHK). Kondisi demikian tentu mengular pada penurunan pendapatan masyarakat setiap harinya. Pendapatan yang rendah ini sangat memberikan imbas pada kurangnya angka kecukupan gizi masyarakat Indonesia. Tentunya keadaan tersebut perlu mendapatkan perhatian dari pemerintah, guna mengembalikan kondisi perekonomian masyarakat di tengah mewabahnya virus covid-19. Salah satunya adalah dengan pemberian pemahaman kepada peserta didik tentang kewirausahaan.

Peserta didik yang memiliki jiwa wirausaha diharapkan dapat memberikan peluang kerja bagi mereka. Untuk mencapai hal tersebut, peserta didik perlu diberikan pengayaan tentang pemahaman mereka terhadap ilmu kewirausahaan. Pendidikan kewirausahaan yang diberikan pada peserta didik sudah dipertimbangkan sebagai salah satu faktor penting dalam menumbuhkembangkan hasrat, jiwa dan perilaku usaha pada peserta didik. Namun, nyatanya terlihat bahwa mental kewirausahaan peserta didik masih terbilang rendah (Powers et al., 2005). Semua ini terjadi karena pembelajaran kewirausahaan yang dilakukan di sekolah masih pada taraf konsep saja, penerapan pada praktiknya masih kurang, sehingga peserta didik belum terbentuk karakter wirausahawan yang ada pada mereka (Lacho and Kenneth, 2010 ). Oleh karena itu diperlukan suatu metode yang tepat dapat pembelajaran kewirausahaan pada peserta didik.

Banyak jenis kewirausahaan yang bisa dijadikan sebagai peluang usaha di masa pandemic. Salah satunya adalah usaha tanaman hias. Usaha jenis tersebut terlihat 
menjanjikan di masa pandemic. Penggemar tanaman hias mulai menjamur dengan keberadaan lockdown yang diterapkan di beberapa daerah di Indonesia. Situasi tersebut menyebabkan masyarakat mengalihkan kegiatan kantor mereka dengan menyibukan diri merawat tanaman hias. Banyak masyarakat yang biasanya tidak terlalu gemar mengoleksi tanaman hias menjadi ikut dengan hobi baru tersebut. Sehingga hal tersebut sangat memberikan peluang usaha baru di tengah masyarakat.

Pengadaan tanaman hias bisa dilakukan dengan cara menjadi reseller atau juga bisa menjadi penyedia tanaman hias. Seorang yang menjadi reseller bisa dengan cara membantu pada penyedia atau orang yang memproduksi tanaman hias untuk menjualkan barang dagangan mereka. Hasil dari penjualannya akan diberikan komisi penjualan pada orang yang telah mempromosikan barang tersebut. Berbeda dengan orang yang menjadi penyedia atau orang yang memproduksi tanaman hias. Orang tersebut harus menyediakan bibit tanaman hias, media tanam dan lahan tempat penanaman.

Produksi tanaman hias tidak membutuhkan lahan yang luas. lahan pekarangan bisa dijadikan sebagai lahan tempat menanam tanaman hias. Banyak teknik menanam tanaman hias di lahan terbatas yang bisa digunakan, salah satunya adalah dengan menggunakan teknik vertical garden. Teknik tersebut adalah teknik penanaman yang disusun secara bertumpuk di dinding dengan menggunakan bantuan media yang direkatkan pada dinding. Metode penanaman tersebut dapat memberikan kesan estetika dan mendapatkan jumlah penanaman yang lebih banyak di lahan yang sedikit. Tanaman yang dapat diaplikasikan menggunakan vertical garden bisa berupa tanaman indoor atau outdoor. Penerapan teknik ini berperan pada perubahan iklim mikro 
dalam bangunan (Wong et al., 2010), seperti rumah dan perkantoran. Karena, dengan keberadaan tanaman hias di lingkungan rumah atau perkantoran dapat memberikan kenyamanan dan menghemat energi (tanpa menggunakan AC), serta memberikan lingkungan yang sehat (Stec et al., 2005 dan Leopanitchakul et al., 2008). Pengetahuan tentang tanaman dan media tanaman yang baik adalah salah satu hal penting dalam usaha tanaman hias.

Menjadi wirausahawan di bidang tanaman hias akan berjalan dengan baik jika orang tersebut memiliki pengetahuan yang baik di bidang tanaman. Pengetahuan yang berhubungan dengan tanaman hias adalah ilmu pengetahuan alam (IPA). Pengetahuan tersebut merupakan suatu usaha yang dilakukan manusia dalam memaknai alam semesta dengan cara mengamati langsung pada sasaran yang dituju menggunakan berbagai prosedur yang terencana sehingga dapat dijelaskan dan diambil sebuah kesimpulan (Susanto, 2013). Pengamatan yang dilakukan dapat berupa penampakan secara langsung tanpa bantuan alat optik atau juga menggunakan bantuan alat optik berupa mikroskop. Adanya pengamatan yang dilakukan secara langsung oleh siswa atau peserta didik dapat meningkatkan pemahaman terhadap objek atau materi yang dipelajari. Peningkatan tersebut berdampak langsung pada nilai hasil belajar mereka.

Metode pembelajaran yang acap kali digunakan di masa pandemic berbeda. Pembelajaran dengan blended learning santer digaungkan oleh pemerintah. Pembelajaran dengan menggunakan metode bauran berupa metode tatap muka (luring) dan metode pembelajaran berbasis online (during). Walaupun penggunaan pembelajaran secara daring terbilang mahal, namun metode tersebut dapat menjawab permasalahan yang terjadi di masa pandemic. 
Karena terbatasnya akses sosial yang diberlakukan pemerintah dengan mengurangi aktivitas berkerumun dalam jumlah besar menjadikan metode during adalah satusatunya cara untuk memenuhi kebutuhan pembelajaran saat ini. Jika dihitung secara tepat, maka mahalnya biaya yang dikeluarkan untuk pembelajaran daring adalah seimbang dengan pengeluaran yang dilakukan untuk menggantikan biaya transportasi jika peserta didik harus datang untuk melakukan pembelajaran tatap muka di sekolah. Hal tersebut sesuai dengan pernyataan, Setyosari, (2015), bahwa pembelajaran daring memiliki beberapa potensi seperti; kemudahan mengakses materi pembelajaran, kebermaknaan belajar dan dapat meningkatkan hasil belajar. Hal ini terjadi karena peserta didik dapat secara langsung melihat teks, gambar, suara, data dan video dua arah tanpa ada halangan atau gangguan dari pihak lain seperti teman di sekitar.

Penanaman pemahaman pada peserta didik tentang pengetahuan IPA yang berhubungan dengan tanaman hias juga mudah dilaksanakan. Peserta didik dapat langsung melakukan demonstrasi dengan berbantuan audio visual. Misalnya, peserta didik dapat langsung mengidentifikasi jenis-jenis tanaman hias yang ada di lingkungan sekitar, seperti rumah mereka. Selanjutnya, mereka melakukan proses pengenalan terhadap media tanam yang baik untuk setiap jenis tanaman hias, berikutnya dengan teknik penanaman dan perawatan yang tepat untuk mendapatkan tanaman yang subur dan bisa berkembangbiak dengan baik. Pada akhirnya, peserta didik diharapkan mampu untuk melakukan pemasaran terhadap hasil produksi tanaman hias yang mereka miliki.

Aktivitas pengenalan pada tanaman hias, media tanam, teknik menanam dan teknik pemasaran pada produk 
tanaman hias yang mereka miliki dijadikan sebagai acuan proses pembelajaran. Proses yang mereka lakukan itu didokumentasi setiap tahapannya. Dokumentasi yang dihasilkan selanjutnya dijadikan sebagai bahan evaluasi oleh pendidik untuk bisa memberikan klarifikasi, konfirmasi atau masukan yang bisa dijadikan sebagai koreksi oleh peserta didik untuk memperbaiki setiap tahapan yang mereka lakukan. Sehingga di akhir kegiatan, peserta didik melakukan pelaporan. Laporan tersebut yang dijadikan sebagai nilai akhir untuk mata pelajaran kewirausahaan tersebut.

Pelaporan yang dibuat peserta didik harus menggambarkan setiap tahapan yang ada dalam aktivitas produksi dan pemasaran tanaman hias yang dilakukan peserta didik. Dengan pemberian pengetahuan kewirausahaan pada peserta didik diharapkan dapat memberikan geliat pada perkembangan wirausaha masyarakat di tengah pandemi covid-19 saat ini. Sehingga kegiatan kewirausahaan yang dilakukan dapat memperbaiki perekonomian masyarakat. 


\section{Daftar Pustaka}

Bwire, G. M., \& Paulo, L. S. (2020). Coronavirus disease2019: Is fever an adequate screening for the returning travelers? Tropical Medicine and Health , 48 (1): 10-12. Doi: 10.1186/s41182-020-00201-2.

Lacho, Kenneth, 2010, Entrepreneurship Education: Another Approach, Small Business Institute Journal. https://www.sbij.org/ article/view/66 index.php/SBIJ/

Powers, Joshua B dan Patricia P. McDougall, 2005, University Start-up Information and Technology Licensing with Firms that Go Public: a ResourceBased View of Academic Entrepreneurship. Doi: 10.1016/j.jbusvent.2003.12.008

Setyosari, P. (2007). Pembelajaran Sistem Online: Tantangan dan Rangsangan. Jurnal Majalah Ilmiah Pembelajaran Edisi Oktober 2007 No.2. Universitas Negeri Yogyakarta. Hal 7-8. https://journal.uny.ac.id/ index.php/mip/article/ view/5992

Stec W.J., Paassen A.H.C., Maziar A., Modelling The Double Skin Facade With Plants, Energy and Buildings , 37 (2005) 419-27.

Doi:

10.1016/j.enbuild.2004.08.008.

Susanto, Ahmad. 2013. Teori Belajar \& Pembelajarandi Sekolah Dasar. Jakarta: Kencana.

Wong N.H., Tan A.Y.K, Chen Y, Sekar K, Tan P.Y, Chan D, Chiang K, Wong N.C., Thermal Evaluation Of Vertical Greenery Systems For Building Walls. Building and Environment, 45 (2010) 663-672. Doi: 10.1016/j.buildenv.2009.08.005 


\title{
PERGESERAN PERAN DOSEN DALAM ERA OVERLOAD INFORMATION
}

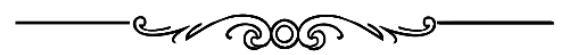

Agep Rumanto, M.E.18

IAIN Kudus

"Jika semula dosen dipandang sebagai sumber ilmu maka dengan adanya teknologi informasi, dosen harus berubah peran menjadi pemfilter informasi yang diterima anak didik."

\begin{abstract}
A l-Ghazzali, dalam kitabnya yang paling monumental yakni Ihya Ulumuddin, menuliskan bab ilmu di bagian paling depan kitab tersebut. Ulama besar kelahiran kota Khurasan, Persia (kini Iran) tersebut menyebutkan seputar ketinggian dan keutamaan ilmu melalui serangkaian ayatayat di dalam al-Quran. Penempatan bab keilmuan di bagian paling depan ini membuat al-Ghazzali seolah ingin mengatakan kepada kita betapa tingginya kedudukan ilmu dalam kehidupan manusia.
\end{abstract}

Terkait hal ini maka manusia berupaya dengan segala cara untuk menuntut ilmu. salah satu cara untuk menuntut ilmu tersebut adalah dengan menghadiri sekolah atau kuliah. Hal ini mengindikasikan bahwa manusia senantiasa dalam keadaan lack of information (kekurangan informasi). Oleh sebab itu maka manusia selalu berperilaku untuk mencari ilmu. Sifat manusia yang haus akan ilmu ini sejalan

18Penulis lahir di Magelang, 13 April 1985, penulis merupakan dosen IAIN Kudus dalam bidang perbankan Syariah. Penulis menyelesaikan gelar sarjana ekonominya di Universitas Gadjah Mada (2011), sedangkan gelar Magister Eknominya diselesaikan di UIN Sunan Kalijaga. 
dengan teori hirarki kebutuhan Maslow yang menyebut bahwa aktualisasi diri (yang mana di dalamnya termasuk perilaku mencari ilmu) termasuk dalam salah satu hirarki kebutuhan manusia. Jadi perilaku untuk selalu mencari ilmu adalah sifat bawaan manusia. Jika kita gabungkan dengan konsep berpikiir Al-Ghazzali maka mencari ilmu adalah bagian dari penemuan jati diri manusia karena menurut AlGhazzali ilmu adalah jalan menuju hakikat, sebuah thariqat menuju Tuhan.

Dalam dunia modern sekarang ini metode paling umum dalam mencari ilmu adalah dengan menghadiri sebuah institusi formal seperti sekolah ataupun kuliah. Sekolah atau kuliah tersebut diampu oleh seseorang yang dijadikan narasumber yang kemudian kita sebut sebagai guru dan dosen. Artinya siswa dan mahasiswa akan menimba ilmu dari guru atau dosen. Itulah konsep transfer keilmuan yang terjadi selama ini.

Kemudian, jaman dengan begitu cepat berubah khususnya dalam hal informasi. Masif dan cepatnya perkembangan teknologi informasi membuat perilaku orang untuk mendapat informasi pun berubah. Kini mereka tidak perlu menghadiri sebuah forum formal (sekolah atau kuliah) untuk mendapat ilmu, melainkan cukup mengakses sebuah informasi lewat sebuah alat yang kemudian disebut gawai.

Kini akses keilmuan ada dalam genggaman mereka. Informasi dari segala penjuru dunia bisa mereka dapatkan dengan begitu cepat dan mudah. Selain kemudahan dan kecepatan, hal yang patut kita perhatikan juga adalah dalam hal informasi apa yang mereka ingin dapatkan. Dengan teknologi informasi yang ada sekarang, semua orang yang memiliki gawai dengan akses internet bisa mendapatkan informasi apa saja yang mereka mau, termasuk dalam dunia 
Pendidikan. Siswa dan mahasiswa mencari bahan materi pembelajaran lewat internet. Fenomena ini tentu menggelitik pikiran kita untuk bertanya, masihkah guru dan dosen diperlukan jika semua orang sudah bisa mendapatkan ilmu dari internet? Tentu saja jawabannya adalah masih. Kenapa? Mari kita urai.

Mudahnya orang mengakses informasi memang banyak memberikan dampak positif, namun tak jarang pula menimbulkan dampak negatif. Di sinilah kemudian masalah bermunculan. Mulai dari mudahnya orang menyebarkan dan menerima berita hoaks hingga kadang kita mengkonsumsi sebuah informasi yang mungkin tidak kita perlukan. Akibatnya kita mengkonsumsi terlalu banyak informasi, kita kemudian menyebutnya dengan overload information, yakni sebuah keadaan dimana kita menerima terlalu banyak informasi hingga kita tidak bisa lagi memilih mana yang benar-benar penting dan kita butuhkan.

Kondisi ini sangat mengkhawatirkan jika sampai terjadi pada anak didik kita. artinya baik mahasiswa ataupun murid mempelajari ilmu yang barangkali sebenarnya tidak perlu mereka ketahui. ini membuat anak didik menjadi susah untuk menemukan fokus dari suatu objek pembelajaran. Kondisi semakin diperparah sejak munculnya pandemic yang membuat cara pembelajaran berubah total. Pandemi Covid seolah membenturkan kepala kita ke tembok agar sadar bahwa cara pembelajaran harus berubah karena jaman sudah berubah. Ini tentu memaksa kita agar memikirkan kembali untuk mencari peran guru atau dosen yang tepat. Maka dari itu pergeseran peran guru atau dosen sudah selayaknya dilakukan, khususnya peran dosen.

Tulisan ini lebih berfokus kepada peran dosen karena dosen lebih banyak bekerja di wilayah keilmuan. Adapun 
guru lebih banyak bekerja di bidang pendidikan yang mencakup akhlak dan budi pekerti. Secara awampun, akhlak dan budi pekerti ini susah digantikan oleh teknologi, bahkan dengan kecanggihan teknologi seperti sekarang. Jadi posisi guru "relatif aman" dibanding dengan dosen. Dosen relatif rentan untuk digantikan dengan teknologi karena peran dosen lebih banyak di ranah keilmuan, sedangkan dengan kecanggihan teknologi seperti sekarang mahasiswa bisa dengan mudah mendapat ilmu tanpa kehadiran seorang dosen. Maka dari itu peran dosen akan digantikan oleh teknologi informasi. Akan tetapi benarkah demikian? Nah, di sinilah peran dosen perlu diubah. Jika semula dosen dipandang sebagai sumber ilmu maka dengan adanya teknologi informasi, dosen harus berubah peran menjadi pemfilter informasi yang diterima anak didik.

Peran seorang dosen diperlukan bukan utamanya untuk mentransferkan ilmunya kepada mahasiswa melainkan karena dosen lebih mengetahui mana informasi yang penting dan dibutuhkan untuk mahasiswanya. maka dari itu dosen dituntut untuk menguasai keilmuannya secara mendalam sehingga dosen akan dengan mudah memangkas informasi-informasi yang tidak dibutuhkan oleh mahasiswa. Jika dosen berpandangan demikian maka dosen tidak bisa digantikan dengan teknologi informasi. Dosen tetap diperlukan dalam hal pengarahan kepada mahasiswa tentang apa yang harus dipelajari. Jadi dosen lebih berperan sebagai seorang pemandu bagi mahasiswanya.

Dosen sebagai pemandu mahasiswa di kelas sebenarnya bukanlah isu baru, isu ini sudah ada sejak lama. Namun pandemi Covid ini memaksa kita agar kembali benar-benar serius dalam menerapakan dosen sebagai pemandu kelas. Dosen sebagai pemandu bukan lagi sebuah 
wacana melainkan benar-benar harus segera diterapkan jika kita tidak ingin bangsa ini semakin ketinggalan dalam dunia pendidikan. Jadi ke depan, seorang dosen wajib memiliki mindset sebagai seorang pemandu mahasiswa di kelas.

Kurikulum merdeka belajar-kampus merdeka (MBKM) juga membawa semangat yang sama. Dalam kurikulum baru tersebut mahasiswa diberikan kebebasan mempelajari apa yang mereka mau, apa yang mereka minati. Artinya sekarang mahasiswa diberi kebebssasan untuk mengekpresikan keinginannya Jika kita tidak hati-hati maka dikhawatirkan justru akan menjerumuskan mahasiswa kita untuk semakin overload information karena tidak ada yang mengontrol tentang apa yang mereka pelajari.

Hal yang perlu diingat adalah bahwa pergeseran peran dosen ini bukan hanya sekedar membekali dosen dengan ketrampilan teknis seputar IT seperti bagaimana membuat video pembelajran yang canggih akan tetapi lebih mendasar daripada itu, yakni sebuah pemahaman mendasar, tentang filosofi dasar peran dosen yang harus segera diubah. 


\section{PEMBELAJARAN DARING DI MASA PANDEMI COVID-19}

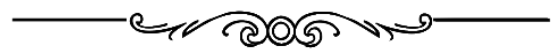

Salisa Maulidiyah, M.Pd19

MIS Tarbiyatussibyan

"Pembelajaran secara daring dengan berbagai tantangan yang harus dihadapi namun juga memiliki sisi positif yang di dapat baik bagi guru maupun siswa."

Semenjak virus Covid-19 yang awalnya mewabah di $\mathcal{S}_{\text {daerah Wuhan (China) masuk ke Indonesia, pemerintah }}$ mulai membatasi interaksi antar manusia di berbagai tempat yang memicu kerumunan (Firman dan Rahman, 2020:81). Salah satu tempat pemicu kerumunan tersebut adalah sekolah. Dikarenakan angka penyebaran virus Covid-19 yang terus meningkat dari hari ke hari, berbagai kebijakan lockdown wilayah diterapkan di berbagai daerah guna menekan angka penyebaran. Dalam bidang pendidikan, guru dan juga siswa harus mengubah pola pembelajaran tatap muka menjadi pembelajaran jarak jauh. Hal ini sejalan dengan surat kebijakan yang dikeluarkan oleh pemerintah Nomor 4 Tahun 2020 tentang Pelaksanaan Kebijakan Pendidikan Dalam Masa Darurat Penyebaran Covid-19, dalam rangka upaya memutus penyebaran rantai virus Covid-19 maka seluruh lembaga pendidikan

${ }^{19}$ Penulis lahir di Tulungagung, 05 Februari 1994, penulis merupakan Guru Bahasa Inggris di MIS Tarbiyatussibyan, penulis menyelesaikan gelar Sarjana Pendidikan Bahasa Inggris di IAIN Tulungagung (2016), sedangkan gelar Magister Pendidikan Guru Madrasah Ibtidaiyah di IAIN Tulungagung (2018). 
diwajibkan untuk menghadirkan alternatif proses pembelajaran selama pandemi Covid-19 .

Pelarangan pembukaan kembali sekolah tentunya bukan tanpa alasan, hal ini dilakukan demi mencegah timbulnya kluster sekolah serta demi keselamatan dan kesehatan para peserta didik. Pembelajaran secara daring (dalam jaringan) dipilih sebagai alternatif untuk tetap melanjutkan proses pembelajaran meskipun dalam keadaan pandemi. Pembelajaran secara daring dipilih karena dianggap paling efektif untuk melakukan proses pembelajaran jarak jauh. Pembelajaran daring menjadi salah satu solusi dalam penerapan social distancing guna mencegah penyebaran mata rantai Covid-19 (Irwanto, 2020:41). Dengan pembelajaran model daring ini, guru dan siswa masih bisa berkomunikasi serta berinteraksi meski dalam dunia maya dengan mengandalkan kecanggihan teknologi, informasi dan komunikasi. Pembelajaran darurat ini memanfaatkan mobile phone yang dimiliki siswa. Penggunaan mobile phone memberikan sumbangan besar dalam dunia pendidikan untuk mendukung pembelajaran daring (Sadikin dkk,2020:216). Beberapa aplikasi pendukung seperti Whatsapp (WA), Youtube, Google Meet, Google Form, Google Classroom, Instagram, dan Facebook dimanfaatkan dalam proses pembelajaran jarak jauh tersebut. Di tingkat sekolah dasar, beberapa alternatif model pembelajaran secara daring dipilih oleh guru :

1. Penugasan Harian

Untuk mendukung proses pembelajaran sehari-hari, aplikasi Whatsapp (WA) dipilih karena dianggap mudah, tidak memakan banyak kuota, serta familiar bagi siswa SD/MI. Berbagai fitur Whatsapp (WA) juga dianggap sangat mudah digunakan untuk berinteraksi antara guru dan siswa. Setiap hari, guru memberikan materi serta 
penugasan melalui grup Whatsapp. Penyampaian materi bisa memanfaatkan Whatsapp Video Call dengan beberapa siswa secara bergantian. Guru juga bisa mengirimkan video pembelajaran atau link pembelajaran yang mendukung materi yang disampaikan melalui Whatsaap. Sebagai evaluasi, siswa cukup memfoto hasil dari pekerjaan mereka melalui Whatsaap grup yang kemudian akan di koreksi oleh masing-masing guru bidang studi.

\section{Penugasan Mingguan}

Beberapa guru lebih memilih untuk memberikan tugas mingguan. Dalam hal ini, guru membagikan beberapa lembar tugas yang berisi link materi yang merujuk pada video atau artikel, rangkuman materi, serta beberapa soal sebagai latihan. Tugas tersebut harus diselesaikan oleh siswa selama satu minggu. Di akhir pekan, siswa wajib melaporkan tugas tersebut dan kemudian guru memberikan tugas untuk satu minggu berikutnya.

\section{Penggunaan fitur kelas virtual}

Untuk tingkat sekolah dasar, penggunaan kelas virtual seperti Google Meet ini jarang kami gunakan karena dianggap memakan banyak kuota, membutuhkan jaringan yang kuat, serta belum familiar di kalangan siswa dan juga orang tua. Pemanfaatan kelas virtual hanya di lakukan beberapa kali oleh guru guna memantau proses pembelajaran siswa di rumah. Aplikasi Google Meet memang sangat bermanfaat karena melalui aplikasi ini guru dapat berkomunikasi dengan seluruh siswa baik dalam rangka menjelaskan materi maupun pemberian motivasi.

4. Pembuatan Video Pembelajaran

Dalam rangka memfasilitasi siswa dalam memahami materi yang dianggap sulit dan perlu penjelasan lebih lanjut seperti mata pelajaran Matematika, guru membuat video 
pembelajaran sederhana. Dengan demikian, siswa di harapkan lebih memahami materi yang disampaikan dan sekaligus merasakan kehadiran seorang guru di tengahtengah proses pembelajaran. Siswa akan lebih antusias untuk menyimak video yang di buat langsung oleh guru. Video pembelajaran yang tersedia di Youtube biasanya belum mencakup materi-materi yang hendak disampaikan atau bahkan sedikit berbeda dengan materi yang dimaksdukan. Supaya siswa benar-benar menyimak video tersebut, maka guru menyisipkan beberapa pertanyaan yang jawabannya termuat dalam video tersebut.

5. Pemanfaatan Google Form

Di akhir pembelajaran, guru biasanya membuat evaluasi pembelajaran untuk siswa. Dalam pembelajaran daring seperti sekarang ini, pemanfaatan google form dijadikan sebagai alternatif untuk mengadakan evaluasi pembelajaran. Guru dapat membuat soal baik pilihan ganda, isian maupun uraian yang kemudian link akan di bagikan kepada siswa. Kemudian, siswa mengerjakan soal secara online dan nilai akan ter input secara otomatis.

Beberapa alternatif pembelajaran yang dipilih di atas tentu bukan tanpa hambatan. Pertama adalah keterbatasan kuota, pembelajaran secara daring tentu memerlukan kuota internet yang lebih banyak dari biasanya. Para siswa harus mengeluarkan biaya tambahan untuk membeli kuota internet (Handarini dan Wulandari,2020:501). Penggunaan beberapa kelas virtual seperti Google Classroom dan Zoom Meeting akan memakan kuota yang cukup besar. Banyak orang tua yang mengeluhkan pengeluaran untuk membeli kuota internet semakin besar sedangkan perputaran roda ekonomi malah semakin menurun. Beberapa bantuan kuota yang ditawarkan oleh pemerintah maupun beberapa operator seluler juga tidak secara rutin di berikan sehingga 
para orang tua tetap merasa terbebani. Kedua adalah jaringan internet yang terbatas, hal kedua yang dikeluhkan oleh beberapa wali murid adalah tentang kekuatan jaringan internet yang ada di rumah mereka masing-masing. Beberapa kegiatan pembelajaran yang memanfaatkan beberapa kelas virtual tidak dapat diikuti dengan baik dikarenakan kondisi jaringan internet yang kurang mendukung. Ketiga adalah penguasaan teknologi yang terbatas, bagi siswa yang masih duduk di bangku sekolah dasar, cukup sulit bagi mereka untuk mengikuti proses pembelajaran secara daring tanpa pendampingan dari orang tua. Beberapa dari mereka berasal dari orang tua yang berpendidikan dan melek teknologi dan ada juga yang berasal dari orang tua yang memiliki kemampuan terbatas dalam menggunakan teknologi. Bagi siswa yang berasal dari keluarga yang memiliki keterbatasan dalam penguasaan teknologi pembelajaran maka akan mengalami banyak kendala dan kesulitan. Keempat adalah sulitnya kontrol dari guru, ketika guru dan siswa tidak bertemu secara langsung dan hanya berinteraksi melalui dunia maya, maka akan terasa sulit bagi guru untuk memantau perkembangan belajar setiap siswa dan juga pemahaman terhadap materi yang di berikan. Tugas yang diselesaikan secara baik dan benar belum cukup untuk di jadikan tolok ukur keberhasilan pembelajaran siswa di rumah. Karena bisa jadi mereka meminta bantuan orang lain dalam menyelesaikannya tanpa sebenarnya memahami betul materi yang disampaikan. Ketidakjujuran siswa dan di dukung oleh ketidakpuasan orang tua membuat beberapa evaluasi pembelajaran menjadi tidak begitu valid untuk dijadikan acuan.

Pembelajaran secara daring dengan berbagai tantangan yang harus dihadapi namun juga memiliki sisi 
positif yang di dapat baik bagi guru maupun siswa. Pertama, guru dan juga siswa terlatih untuk melek teknologi. Mereka lebih terbiasa dalam memanfaatkan IT. Kedua, pembelajaran daring melatih kemandirian siswa untuk belajar. Siswa menjadi terlatih untuk mencari informasi tambahan melalui sumber-sumber lain seperti google, youtube serta aplikasi lainnya. Ketiga, pembelajaran jarak jauh juga melatih guru untuk lebih kreatif dalam mengemas pembelajaran agar lebih menarik dan mudah di pahami oleh siswa. Keempat, pembelajaran daring juga dinilai lebih paraktis dan fleksibel karena bisa dikerjakan kapanpun dan juga dimanapun. Bagi orang tua yang bekerja, pembelajaran daring sangat memudahkan mereka untuk mengatur waktu dalam mendampingi siswa belajar (Anugrahana, 2020:287). Keberhasilan sistem pembelajaran daring sangat bergantung dari beberapa komponen. Jika komponen tersebut dapat terintegrasi dengan baik maka dapat menghasilkan lulusan yang berkualitas (Rosali, 2020:28). Komponen tersebut dapat meilputi guru, siswa, sumber belajar dan teknologi yang tersedia. 


\section{Daftar Pustaka}

Anugrahana, Andri. 2021. Hambatan, Solusi, dan Harapan:

Pembelajaran Daring Selama Masa Pandemi Covid-

19 Oleh Guru Sekolah Dasar. Jurnal Pendidikan dan Kebudayaan Vol 10, No 3.282-289.

Dokumen Surat Edaran Nomor 4 Tahun 2020 tentang Pelaksanaan Kebijakan Pendidikan Dalam Masa Darurat Penyebaran Coronavirus Disease (Covid19) dalam format PDF ini ditandatangai oleh Menteri Pendidikan dan Kebudayaan Nadiem Makarim pada tanggal 24 Maret 2020.

Firman dan Rahman, Sari Rahayu. 2020. Pembelajaran Online di Tengah Pandemi Covid-19. Indonesian Journal of Education Science (IJES). Vol 02, No 02.

Ika Handarini, Oktafia, Siti Wulandari, Sri. 2020. Pembelajaran Daring Sebagai Upaya Study From Home (SFH) Selama Pandemi Covid 19. Jurnal Pendidikan Administrasi Perkantoran (JPAP).Vol 8 No 3.

Irwanto.2020. Pelaksanaan Pembelajaran Online (Daring) di Program Studi Pendidikan Vokasional Teknik Elektro UNTIRTA di Masa Pandemi Covid-19. Prosiding Seminar Nasional Pendidikan FKIP Vol 3 No 1 (28-44).

Sadikin, Ali, dkk. 2020. Pembelajaran Daring di Tengah Wabah Covid-19. Jurnal Ilmiah Pendidikan Biologi. Vol 6 No 2 : 214 -224. Doi : 10.22347/bio.v612.9759.

Satiyasih Rosali, Ely. 2020. Aktifitas Pembelajaran Daring Pada Masa Pandemi Covid-19 di Jurusan Pendiidkan Geografi Universitas Siliwangi Tasikmalaya. Geography Science Education Journal. Vol 01, No 01. 


\title{
MENAKAR KESIAPAN DAN PARTISIPASI PESERTA DIDIK DALAM PEMBELAJARAN DARING SELAMA MASA PANDEMI COVID- 19 DI KABUPATEN SIKKA, NTT
}

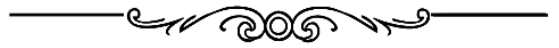 \\ Marianus Yufrinalis, S.Fil., M.A ${ }^{20}$ \\ Universitas Nusa Nipa Indonesia
}

\begin{abstract}
"Berbicara tentang kesiapan dan partisipasi peserta didik dalam pembelajaran daring selama masa Pandemi Covid-19, tentu berpijak pada alasan mendasar terkait pemenuhan kebutuhan pribadi pada akses informasi dan komunikasi, serta karakter peserta didik itu sendiri."
\end{abstract}

Pandemi Covid-19 telah menyita banyak perhatian, tenaga, sumber daya, dan sisi finansial kehidupan manusia di dunia. Rizal (2020) menyebut setidaknya tiga dampak buruk pandemi Covid-19 kepada tatanan masyarakat Indonesia yakni tingginya angka kematian tenaga kesehatan (dokter dan perawat) sebagai garda terdepan penanganan pandemi, adanya resesi ekonomi di berbagai bidang, dan perubahan paradigma belajar baru sebagai akibat dari adanya pembatasan kegiatan

20Penulis lahir di Maumere pada tanggal 18 Februari 1987, menamatkan pendidikan S1 Ilmu Filsafat pada tahun 2010 di STFK Ledalero, Maumere, Flores, NTT. Kemudian pada tahun 2011 penulis melanjutkan pendidikan S2 Ilmu Sosiologi di Pascasarjana FISIPOL Universitas Gadjah Mada Yogyakarta dan tamat pada tahun 2013. Saat ini bertugas sebagai Dosen Ilmu Sosial Dasar dan Filsafat Pendidikan pada Program Studi PGSD Universitas Nusa Nipa Indonesia di Maumere, Flores, NTT. 
masyarakat, yaitu penerapan pembelajaran jarak jauh (daring). Beberapa aspek penting kehidupan manusia, khususnya aspek-aspek yang menguasai hajat hidup orang banyak, turut terdampak dan tidak memberikan kontribusi positif bagi pemenuhan kebutuhan hidup umat manusia. Sebut saja, aspek kesehatan, pendidikan, dunia usaha dan dunia industri (DUDI), lembaga pemerintahan dan swasta, serta aktivitas pokok manusia, menjadi terbatas dan tidak menunjang kebutuhan manusia itu sendiri.

Dalam tulisan ini, penulis menyoroti aspek pendidikan dan pelaksanaan pembelajaran di tengah wabah Covid-19 dengan menekankan kesiapan dan semangat partisipatif siswa di wilayah Kabupaten Sikka, NTT, melalui penggunaan media elektronik dan media online sebagai fasilitas penunjang pembelajaran.

\section{Pandemi Dan Stabilitas Masyarakat}

Ketika berbicara tentang dampak pandemi terhadap stabilitas masyarakat, pada hemat penulis, ada beberapa aspek terdampak sebagaimana diutarakan dalam pengantar di atas. Pandemi telah menyebabkan kemunduran dalam perekonomian masyarakat, sebagaimana dikenal dengan istilah resesi ekonomi. Di Indonesia, dampak pandemi terhadap stabilitas masyarakat, khususnya stabilitas ekonomi, dapat dilihat pada adanya dampak ikutan dari resesi ekonomi global. Resesi dianggap sebagai bagian tak terhindarkan dari siklus bisnis yang terjadi dalam perekonomian suatu negera (Shalihah, 2020). Resesi ditunjukkan dengan adanya kontraksi sebesar minus 2,03\% yoy (Virdita, 2020). Menilik ke belakang, perekonomian Indonesia pada kuartal II-2020 tercatat sebesar minus 5,32\% yoy. Perekonomian pada kuartal tersebut tertekan akibat pandemi Covid-19. 
Pandemi membuat chaos dalam kehidupan masyarakat dan stabilitas masyarakat terganggu. Menurut Ian Stewart (Piliang, 201: 305), chaos mengacu pada situasi ketidakteraturan atau kekacauan benda (benda, ekonomi, sosial, politik, budaya dan keamanan), yang tidak bisa diprediksi polanya, dan terjadi di mana-mana namun sukar untuk dijelaskan. Akan tetapi, situasi kacau yang ditimbulkan pandemi ini juga pada sisi yang lain menimbulkan keberaturan. Chaos yang ditimbulkan seyogyanya menyebabkan paradigma baru, perubahan pola perilaku, dan tatanan dunia baru. Chaos tidak semestinya menjadi hal yang menunjuk pada ketidak teraturan, karena di balik sisi ketidakberaturannya itu, mengisi situasi lain yang dikatakan sebagai keteraturan (stabil). Chaos karena Pandemi Covid-19 juga serentak melahirkan stabilitas masyarakat yang baru dan kembali pada tata aturan yang sebenarnya (Wardiono, 2012 : 148).

\section{Belajar Dari Rumah: Menakar Kesiapan Dan Partisipasi Peserta Didik}

Di Kabupaten Sikka, salah satu kabupaten di wilayah Provinsi NTT dan terletak di bagian tengah Pulau Flores, dampak Pandemi Covid-19 turut dirasakan oleh masyarakat dalam berbagai bidang kehidupannya. Dalam bidang pendidikan, sekolah-sekolah diliburkan untuk jangka waktu yang tidak pasti menurut himbauan dari satuan tugas percepatan penanganan pandemi Covid-19. Pemerintah setempat membatasi aktivitas pembelajaran di sekolah dengan menerapakan kebijakan Belajar Dari Rumah (BDR). Setiap sekolah diberi kewenangan untuk mengatur pendidik (guru) dan peserta didik menerapkan pola pembelajaran jarak jauh sesuai dengan tingkat kebutuhan dan kondisi di lapangan. 
Ketika guru melakukan kegiatan pembelajaran daring, guru memanfaatkan perangkat atau media elektronik di sekolah agar memudahkan koordinasi oleh kepala sekolah sehingga aktivitas mengajar guru dan siswa bisa terpantau efektif. Di sekolah para guru mendapatkan jadwal mengajar daring secara bergiliran sesuai dengan jumlah kelas yang ada. Di sini kepala sekolah berperan sebagai manajer kegiatan pembelajaran, dapat memantau perkembangan kegiatan pembelajaran daring, mengevaluasi partisipasi dan efisiensi kegiatan, serta menentukan persentase keberhasilan studi siswa berdasarkan laporan perkembangan pembelajaran oleh guru mata pelajaran dan wali kelas.

Tentu saja, penerapan pembelajaran daring ini tidak selamanya berjalan mulus. Guru dapat lebih mengakrabkan diri dengan pengetahuan berbasis jejaring digital karena hampir semua informasi pengetahuan dewasa ini lebih banyak mudah diakses melalui berbagai perangkat IT dan platform media online. Akan tetapi, kemungkinan terbanyak yang terjadi adalah guru dan peserta didik cenderung mengakses pengetahuan dan informasi lain di luar tuntutan materi pembelajaran yang harus diikuti. Peserta didik menjadi jenuh dalam kegiatan pembelajaran dan tidak suka "diajari" tanpa harus bertemu langsung dengan gurunya.

Sebagai contoh, penggunaan platform media online sebagai media belajar daring belum sepenuhnya dimanfaatkan secara maksimal oleh guru dan peserta didik di sekolah tersebut. Alasannya karena siswa tidak memiliki handphone atau tidak memiliki pulsa data. Belum lagi, tingkat pengawasan guru mata pelajaran dan guru wali kelas tidak seefisien seperti pada pembelajaran tatap muka pada umumnya, mengingat peserta didik hanya bisa hadir 
secara virtual dari perangkat telekomunikasinya masingmasing (2020). Tentu saja, kondisi ini menjadi refleksi penting untuk semua stakeholders terkait kebijakan yang mumpuni untuk menerapkan konsep Belajar Dari Rumah yang berkeadilan, peka situasi, dan adaptable dalam situasi Pandemi Covid-19.

Berbicara tentang kesiapan dan partisipasi peserta didik dalam pembelajaran daring selama masa Pandemi Covid-19, tentu berpijak pada alasan mendasar terkait pemenuhan kebutuhan pribadi pada akses informasi dan komunikasi, serta karakter peserta didik itu sendiri. Mengapa? Alasan pertama yang dimunculkan dalam diskusi ini, adalah tingkat penghasilan orang tua atau wali peserta didik yang cenderung menurun selama masa Pandemi Covid-19. Berkurangnya penghasilan setiap keluarga tentu saja berpengaruh pada upaya pemenuhan kebutuhan pokok (primer), sekunder dan tersier.

Tentu saja, adanya tuntutan terhadap kesiapan para orang tua untuk memfasilitasi kebutuhan belajar dari anakanaknya, menjadi hal yang sering kontradiktif dengan keadaan sebenarnya. Banyak orang tua mengeluh karena tidak sanggup atau tidak siap secara finansial agar anaknya bisa mengikuti pembelajaran secara online. Tambahan pula, mentalitas anak-anak yang easy going, instant, dan malas tau menjadi salah satu hambatan bagi orang tua dan pihak sekolah dalam menerapkan pembelajaran daring berbasis platform digital.

Menanggapi kondisi ini, pemerintah turut membantu masyarakat dengan memberikan bantuan jaring pengaman sosial dalam berbagai bentuk dan skema. Dalam dunia pendidikan, sebagaimana dilansir dari laman Kementerian Pendidikan dan Kebudayaan RI (2020), pemerintah telah meluncurkan bantuan pulsa data. Program ini dilanjutkan 
sampai tahun 2021 ini dengan rincian kuota internet untuk jenjang PAUD sebesar 7 GB perbulan, jenjang pendidikan dasar dan menengah sebesar $10 \mathrm{~GB}$ perbulan, para pendidik jenjang PAUD hingga pendidikan dasar dan menengah sebesar 12 GB per bulan, serta bagi dosen dan mahasiswa sebesar 15 GB per bulan (2021).

Alasan kedua, sejauh ini dapat dipertanyakan, apakah program kegiatan belajar dari rumah ini sudah sangat efisien dan efektif diterapkan di semua sekolah. Pada pengamatan penulis, kegiatan belajar dari rumah dengan menggunakan platform digital tidak berjalan efektif. Salah satu penyebabnya adalah karakteristik peserta didik yang tidak terlibat aktif dalam pembelajaran dengan berbagai alasan. Dari petikan wawancara penulis dengan beberapa guru, dijelaskan bahwa hanya sebagian saja peserta didik yang ikut join dalam link kegiatan pembelajaran (2020).

Kondisi-kondisi berdasarkan dua alasan di atas menjadi kesimpulan yang diambil penulis jika penerapan program belajar dari rumah oleh pemerintah dan pihak sekolah, dalam konteks tempat di wilayah Kabupaten Sikka, tidak dapat terlaksana secara maksimal. Hal ini disebabkan karena kesiapan orang tua dan peserta didik secara finansial kurang memadai serta tingkat partisipasi aktif peserta didik dalam pembelajaran daring tidak maksimal. 


\section{Daftar Pustaka}

Kementerian Pendidikan dan Kebudayaan. 2020. Kemendikbud Resmikan Kebijakan Bantuan Kuota Data Internet 2020. https://www.kemdikbud.go.id/ main/blog/2020/09/kemendikbud-resmikankebijakan-bantuan-kuota-data-internet-2020, diakses pada tanggal 29 April 2021

Kementerian Pendidikan dan Kebudayaan. 2021. BantuanKuota Data Internet 2021 Kementerian Pendidikan dan Kebudayaan Rincian Bantuan. https://kuota-belajar.kemdikbud.go.id/ , diakses tanggal 29 April 2021

Piliang, Yasraf Amir. 2001. Sebuah Dunia Yang Menakutkan : Mesin-Mesin Kekerasan Dalam Jagat Raya Chaos. Bandung : Mizan

Rizal, Jawahir Gustav. 2020. Kilas Balik 9 Bulan Pandemi Covid-19 dan Dampaknya Bagi Indonesia. https://www.kompas.com/tren/ $\mathrm{read} / 2020 / 08 / 04 /$ 151000465/mengenal-apa-ituresesi-ekonomi-dampak-dan-penyebabnya?page=all. Diakses tanggal 27 April 2021.

Shalihah, Nur Fitriatus. 2020. Mengenal Apa Itu Resesi Ekonomi, Dampak, dan Penyebabnya. https://www.kompas.com/tren/read/2020/12/03 /063000665/kilas-balik-9-bulan-pandemi-covid19-dan-dampaknya-bagi-indonesia?page=all.

Diaksestanggal 26 April 2021

Virdita, Ratriani. 2020. Apa Itu Resesi Ekonomi dan Dampaknya Yang Resmi Dialami Indonesia. https://nasional.kontan.co.id/news/apa-itu-resesiekonomi-dan-dampaknya-yang-resmi-dialamiindonesia. Diakes tanggal 28 April 2021

Wardiono, Kelik. 2012. CHAOS THEORY: Sebuah Ancangan Dalam Memahami Hukum. Jurnal Ilmu Hukum. Vo. 15, No.2, September 2012: 136-148 


\section{BAB III:}

\section{PSIKIS, NILAI DAN KARAKTER PEMBELAJARAN DARING}

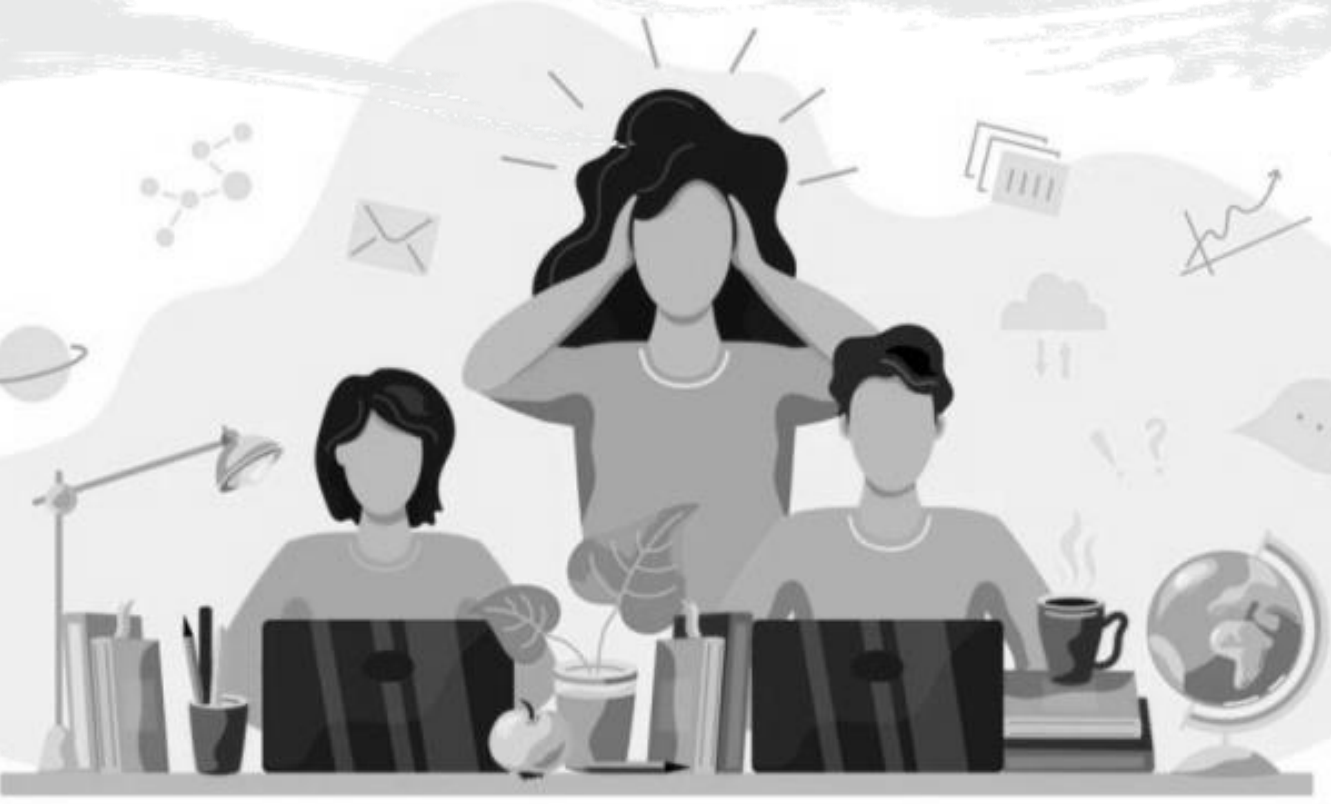




\title{
DUKUNGAN PSIKOSOSIAL BAGI MAHASISWA DI MASA PANDEMI COVID-
}

19

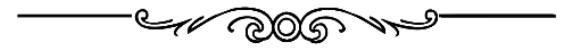 \\ Mariana Ikun RD Pareira, M.Psi.T., Psikolog21 \\ Universitas Nusa Cendana
}

"Reaksi-reaksi psikologis yang dijabarkan merupakan reaksi yang umum terjadi pada masyarakat ketika mengalami stress maupun krisis, namun jika dibiarkan terus dan tidak ditangani, akan menghambat proses belajar mahasiswa dan bahkan akan menjadi gangguan yang lebih serius."

Pandemi Covid-19 yang terjadi saat ini mengubah dunia pendidikan. Banyak sekolah yang tutup dan para pelajar menjalani pendidikan tidak di dalam kelas. Di Indonesia sekitar 626.200 sekolah ditutup karena virus corona mulai dari jenjang PAUD hingga perguruan tinggi (Al Faqir, 2020). Sebagai akibatnya, terjadi perubahan pendidikan yang dramatis dan meningkatnya pembelajaran e-learning dimana pembelajaran dilakukan jarak jauh dan menggunakan platform digital.

Perubahan pendidikan akibat virus corona terjadi tibatiba dan tidak pernah dibayangkan sebelumnya. Hal ini

21Penulis lahir di Kefamenanu, Kabupaten TTU, Nusa Tenggara Timur pada 28 Januari 1976, penulis merupakan Dosen Universitas Nusa Cendana dalam bidang ilmu Psikologi, penulis menyelesaikan gelar Sarjana Psikologi Universitas Katolik Indonesia Atma Jaya (2000), gelar Psikolog (2004), sedangkan gelar Magister Psikologi Terapan Peminatan Anak Usia Dini diselesaikan di Universitas Indonesia (2016). 
dirasakan bukan hanya secara nasional melainkan internasional. Menurut Widodo, Wibowo, dan Wagiran (2020), Covid-19 mengubah sistem pendidikan yang meliputi kurikulum, fungsi pendidik, kedudukan pendidik, dan penilaian. Covid-19 juga mengubah cara mendidik generasi masa depan dan bahkan menyebabkan pendefinisian ulang mengenai peran pendidik.

Perubahan yang terjadi dalam dunia pendidikan khususnya di perguruan tinggi merupakan tantangan bukan saja bagi para dosen, melainkan bagi para mahasiswa agar bisa tetap belajar di masa pandemi Covid-19. Perubahan yang terjadi bisa berdampak positif maupun negatif. Salah satu dampak positif yang dirasakan yaitu menjadi lebih terampil menggunakan media pembelajaran digital. Ketiadaan pembelajaran konvensional melalui tatap muka memicu dosen dan mahasiswa untuk mempelajari mediamedia digital untuk memperlancar proses pembelajaran dalam jaringan (daring). Walaupun demikian, terdapat banyak kendala yang dialami akibat perubahan pembelajaran dari tatap muka secara langsung menjadi pembelajaran daring.

Berdasarkan penelitian yang dilakukan Hutauruk dan Sidabutar (2020), kendala dalam pembelajaran daring dibagi menjadi sembilan bagian yang berkaitan dengan (1) jaringan internet, (2) media pembelajaran, (3) aplikasi yang digunakan dalam pembelajaran, (4) kesiapan bahan ajar, (5) pemahaman materi pelajaran, (6) penyampaian materi oleh dosen, (7) dukungan orangtua, (8) ekonomi keluarga, (9) bantuan dana dari pemerintah/pihak lainnya. Kendala yang paling banyak dirasakan adalah lambatnya jaringan internet, aplikasi yang ngadat ketika mengumpulkan tugas, bahan ajar yang terbatas, kesulitan memahami 
pembelajaran melalui daring, komunikasi menjadi terbatas karena melalui aplikasi.

Temuan dari penelitian Hutauruk dan Sidabutar juga tampak pada hasil survey terbatas yang dilakukan pada beberapa mahasiswa di Prodi Pendidikan Luar Sekolah Universitas Nusa Cendana, Kupang. Lambatnya jaringan internet dan kesulitan memahami materi pelajaran secara daring menjadi isu yang dikeluhkan oleh mahasiswa. Satu kendala lain yang muncul adalah keterbatasan kuota sehingga mahasiswa kadang tidak mengikuti pembelajaran hingga selesai.

Berbagai dampak baik positif dan negatif akibat pandemi membuat mahasiswa dan masyarakat pada umumnya harus menerima sebagai bagian dari kenormalan baru (new normal). Menghadapi perubahan yang terjadi juga dapat mengakibatkan ketidaknyamanan hingga membuat mahasiswa stress. Ketika stress terjadi maka akan muncul reaksi-reaksi psikologis yang mencakup reaksi fisik, kognitif, emosi, sosial, dan spiritual (Wahana Visi Indonesia, 2020). Contoh reaksi-reaksi psikologis yang muncul saat stress dapat dilihat pada tabel berikut:

Tabel 1. Tabel Reaksi-reaksi psikologis

\begin{tabular}{|l|l|l|l|l|}
\hline Fisik & Kognitif & Emosi & Sosial & Spiritual \\
\hline Tegang & Bingung & Khawatir & $\begin{array}{l}\text { Mudah } \\
\text { curiga }\end{array}$ & $\begin{array}{l}\text { Pengahata } \\
\text { n iman }\end{array}$ \\
\hline Pusing & $\begin{array}{l}\text { Sulit } \\
\text { konsent } \\
\text { rasi }\end{array}$ & Cemas & Perundungan & $\begin{array}{l}\text { Pola } \\
\text { ibadah } \\
\text { yang } \\
\text { berubah }\end{array}$ \\
\hline Mual, dll & $\begin{array}{l}\text { Mudah } \\
\text { lupa, dll }\end{array}$ & Takut & Menarik diri & \\
\hline
\end{tabular}

Reaksi-reaksi psikologis yang dijabarkan merupakan reaksi yang umum terjadi pada masyarakat ketika 
mengalami stress maupun krisis, namun jika dibiarkan terus dan tidak ditangani, akan menghambat proses belajar mahasiswa dan bahkan akan menjadi gangguan yang lebih serius. Ketangguhan mahasiswa dalam menghadapi perubahan merupakan hal terpenting. Menjadi tangguh berarti memiliki kemampuan untuk menghadapi tantangan (stress) dan krisis secara efektif (Firda \& Haksama, 2020).

Menjadi tangguh diperlukan suatu proses, pertama perlu mengenali masalah yang dialami dan reaksi psikologis yang muncul. Kedua, memikirkan penanganan atau solusi yang bisa diambil. Ketiga, mencari sumber dukungan baik keluarga maupun komunitas yang membantu agar cepat pulih dari stress atau krisis. Berdasarkan penelitian yang dilakukan oleh penulis mengenai stress dan dukungan sosial pada mahasiswa di Kota Kupang, ditemukan bahwa semakin banyak dukungan sosial yang dimiliki mahasiswa akan mengurangi stress yang dialami.

Lantas, dukungan psikososial seperti apa yang dibutuhkan mahasiswa? Dukungan psikososial diartikan sebagai suatu proses untuk membangun kesejahteraan (well-being) seseorang dengan menggunakan sumber dayanya sendiri dan juga sumber daya yang ada di lingkungan sosialnya (Wahana Visi Indonesia, 2020). Tujuan dari dukungan psikososial adalah mengurangi dampak negatif stress dan mencegah timbulnya gangguan kesehatan mental yang lebih buruk yang disebabkan oleh situasi bencana atau krisis (Everly dalam Cahyono, 2015).

Salah satu dukungan psikososial yang bisa dilakukan adalah dengan memberikan Dukungan Psikologis Awal (DPA). Istilah DPA juga dikenal dengan Psychological First Aid (PFA). DPA merupakan serangkaian keterampilan dasar yang praktis dan bertujuan untuk mengurangi dampak negatif stres, mencegah timbulnya gangguan kesehatan 
mental yang lebih buruk yang disebabkan oleh bencana atau situasi kritis, dan memperkuat proses pemulihan. DPA dapat dianalogikan dengan pertolongan pertama yang diberikan untuk menyelamatkan seseorang yang kehilangan nyawa di dunia kesehatan (Cahyono, 2015).

Memberikan DPA kepada mahasiswa perlu dilakukan dengan tiga kerangka kerja yaitu Safety (aman), Fuction (fungsi), dan Action (aksi). Tiga komponen ini yang perlu difasilitasi oleh pemberi layanan. Tiga target utama dalam layanan ini adalah (1) memberikan rasa aman bagi orang yang membutuhkan dukungan, (2) mendorong keberfungsian bagi orang yang memerlukan dukungan, dan (3) memfasilitasi tindakan orang yang membutuhkan dukungan bagi pemulihannya. Dalam menjalankan DPA, ketiga target ini dijadikan acuan dengan melihat konteks budaya setempat dan orang yang membutuhkan dukungan.

Ketika memberikan DPA kepada mahasiswa, langkah pertama yang dilakukan adalah mengenali kebutuhan dari mahasiswa. Langkah kedua adalah melakukan kontak dengan mahasiswa yang membutuhkan dukungan dan menjalin hubungan yang hangat dan pengertian. Memberikan rasa aman kepada mahasiswa akan memudahkan dalam memperoleh informasi. Timbulnya rasa percaya mahasiswa kepada dosen mendukung proses pemulihan dari stress. Langkah berikutnya adalah memfasilitasi keberfungsian, misalnya mahasiswa tidak mengerjakan tugas atau mengalami masalah di rumah maka penyedia layanan mendorong agar mahasiswa berpikir jernih mengenai masalah yang dialami dan memikirkan tindakan yang bisa dilakukan untuk mengatasinya. Perhatian yang diberikan melalui kata-kata dan perbuatan yang tidak menyakiti merupakan salah satu pendekatan untuk mendorong keberfungsian mahasiswa. 
Langkah yang terakhir adalah memfasilitasi pemulihan dari stress yang dialami mahasiswa dengan membuat rencana tindak lanjut. Misalnya mahasiswa yang tertekan karena mengalami kesulitan dalam menyelesaikan skripsi, diajak untuk membuat rencana penyelesaian tugas akhirnya dengan mengembalikan pada rutinitasnya dan tetap memelihara kontak untuk memotivasi agar bangkit dari situasi yang tidak menyenangkan. 


\section{Daftar Pustaka}

Al Faqir, Anisyah. 2020. Kemendikbud Catat 646.200 Sekolah Tutup Akibat Virus Corona. https://www.merdeka.com/uang/kemendikbudcatat-646200-sekolah-tutup-akibat-viruscorona.html

Cahyono. 2015. Psychological First Aid. Sebuah Kesiapsiagaan Dari Kita Untuk Kita. Depok: Pusat Krisis Fakultas Psikologi Universitas Indonesia.

Firda, Amanatul A., Haksama, Setya. 2020. Membangun Resiliensi Sistem Kesehatan Selama Krisis Covid-19. Jurnal Administrasi Kesehatan Indonesia. 8(1):1-3. Doi: $10.20473 /$ jaki/V8i2.2020.1-3.

Hutauruk, Agusmanto., Sidabutar, Ropinus. 2020. Kendala Pembelajaran Daring Selama Masa Pandemi di Kalangan Mahasiswa Pendidikan Matematika: Kajian Kualitatif Deskriptif. Journal of Mathematics Education and Applied. 2(1):45-51.

Wahan Visi Indonesia. 2020. Buku Saku Dukungan Psikososial Bagi Guru dan Siswa Tangguh di Masa Pandemi Covid-19. Tangerang Selatan: WVI.

Widodo, SFA., Wibowo YE., Wagiran, W. 2020. Online Learning Readiness During The Covid-19 Pandemic. Journal of Physics: Conference Series 1700. 2020 Oct 5. Doi: 10.1088/1742-6596/1700/1/012033. 


\section{PROSES PEMBELAJARAN DARING DAN PEMBENTUKAN KARAKTER PESERTA DIDIK DI MASA PANDEMIK COVID 19}

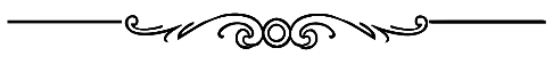

Hiljati, S.Ag.,M.Pd,I.22

IAI DDI Polewali Mandar

"Pembentukan karakter anak tidak boleh terjeda hanya karena adanya pandemik. Bahkan dengan kondisi ini orangtua serta keluarga dari peserta didik seharusnya memaksimalkan fungsinya dalam pembentukan karakter anak dan memaksimalkan fungsi rumah sebagai ruang belajar yang menyenangkan bagi anak-anaknya."

$\mathrm{M}$ asa pandemik covid 19 merupakan suatu fenomena di mana masyarakat di dalam beraktifitas harus terikat dengan protokol kesehatan sebagai salah satu upaya dalam memutus mata rantai penyebaran virus coid 19 tersebut. Pemutusan mata rantai tersebut atau lebih dikenal dengan protokol kesehatan memberi dampak yang besar terhadap aktivitas manusia. Dampak tersebut tidak hanya mempengaruhi sistem sosial masyarakat tetapi juga mempengaruhi banyak bidang sektor dalam kehidupan manusia. Proses pembelajaran serta semua yang terkait dengan pembelajaran itu sendiri merupakan salah satu

22Penulis lahir di Polewali, 25 Pebruari 1971, penulis merupakan Dosen IAI DDI Polewali Mandar dalam bidang Aqidah Akhlak, penulis menyelesaikan gelar Sarjana Agama di IAIN Alauddin Ujungpandang (1995), sedangkan gelar Magister Pendidikan Islam diselesaikan di UIN Alauddin Makassar (2010), 
sektor yang sangat berdampak dengan kondisi pandemik covid 19 ini.

Proses pembelajaran sebagai salah satu sistem yang terdampak mengalami perubahan yang berbeda dengan pembelajaran sebelum masa pandemik. Bersamaan dengan status pandemik ini maka proses pembelajaran kemudian berlangsung di rumah baik secara during ataupun secara luring. Hal ini dilakukan untuk meminimalkan atau memutus rantai penyebaran virus covid 19 dan sekaligus memberikan pengalaman belajar yang bermakna bagi peserta didik. Pembelajaran secara during, maka komunikasi atau proses pembelajaran dilakukan secara online dengan memanfaatkan beberapa aplikasi di media yang dapat memudahkan pembelajaran. Adapun media tersebut seperti whatsapp, zoom, class room, dan beberapa aplikasi lainnya yang dianggap dapat membantu dan memudahkan guru dan peserta didik dalam proses pembelajaran. Pada penggunaan beberapa aplikasi tersebut tentunya didukung dengan ketersediaan sarana dan jaringan. Pada proses pembelajaran ini guru dan peserta didik berada di tempat yang berbeda dan terhubung melalui aplikasi. Proses pembelajaran daring berlangsung di mana guru dalam penyampaian bahan ajarnya secara online dan semua rangkaian pembelajaran berlangsung secara daring atau online. Adapun peserta didik yang menerima bahan ajar juga secara daring atau online di rumah masing-masing namun tetap dalam pantuan atau pendampingan orang tua serta keluarga mereka masingmasing. Maka tentunya aktivitas dan pembelajaran dapat bervariasi sesuai minat dan kondisi masing-masing termasuk mengenai kesenjangan akses atau fasilitas belajar di rumah. Produk aktivitas belajar diberi umpan balik bersifat kualitatif, bukan menjadi keharusan memberi skor 
kuantitatif. Belajar dari rumah bukan berarti guru hanya memberikan tugas kepada peserta didik tetapi sebaiknya juga menjalin komunikasi dan berinteraksi membantu peserta didik dalam mengerjakan tugas-tugas mereka. Meskipun melalui kelas secara online.

Berbeda dengan pembelajaran secara during, maka pembelajaran secara luring tetap rumah sebagai kelas tempat belajar namun tanpa pemanfaatan jaringan. Pada proses pembelajaran ini guru mendatangi rumah peserta didik atau tempat yang disepakati antara guru dan orang tua peserta didik sebagai tempat berlangsungnya pembelajaran misalnya rumah peserta didik atau mesjid. Proses ini dilakukan oleh pihak sekolah atau guru karena keterbatasan akses yang dimiliki peserta didik sementara proses pembelajaran harus tetap berlangsung. Selain itu, kebiasaan belajar di sekolah kemudian berpindah ke rumah menimbulkan masalah baru, ada yang cepat dapat teratasi dan ada pula yang tidak. Mengenai ketersediaan fasilitas belajar, yang sudah ada di sekolah kemudian dapat dimanfaatkan pada proses pembelajaran selama masa pandemik seperti buku dan alat olahraga serta beberapa media pembelajaran yang dapat disediakan oleh guru dan orangtua peserta didik. Namun juga ada beberapa media yang tidak dimanfaatkan pada proses pembelajaran selama masa pandemik baik pembelajaran secara during maupun secara luring karena keterbatasan ruang gerak guru dan peserta didik.

Memasuki tahun kedua masa pandemik covid 19 pembelajaran tetap berlangsung meskipun tidak seperti biasanya. Sekolah dan kelas belajar bergeser ke kelas online dan tentunya memberi kerepotan sendiri bagi sebagian masyarakat Indonesia. Masyarakat kita secara umum masih tetap menganggap pembelajaran yang sesungguhnya adalah 
di sekolah dan berlangsung di kelas. Kondisi pandemik ini belum sepenuhnya dapat mempertegas bahwa belajar tidaklah selamanya di sekolah, tidaklah selamanya dalam kelas yang di sekolah. Karena kenyataan yang dihadapkan pada kita adalah pembelajaran tetap berlangsung meskipun tanpa sekolah dan tanpa kelas yang di sekolah. Proses pembelajaran dapat berlangsung dengan memanfaatkan teknologi. Meskipun penerapan teknologi dalam proses pembelajaran ini tidak sepenuhnya dapat membantu proses belajar mengajar. Harus kita mengakui bahwa pemanfaatan teknologi dalam proses pembelajaran yang berlangsung selama masa pandemik ini memperlihatkan pada kita kenyataan bahwa guru dan orang tua peserta didik tidak semua mahir memanfaatkan teknologi yang terkini. Juga keterbatasan akses yang dimiliki oleh sebagian orang tua peserta didik. Semua ini menjadi catatan penting bagi kita untuk menuju merdeka belajar. Selain keterbatasan kemampuan, keterbatasan akses yang kita hadapi dalam proses pembelajaran di masa pandemik maka yang tidak kalah pentingnya adalah bagaimanakah proses pendidikan karakter peserta didik kita selama belajar dari rumah. Apakah menjadi tanggung jawab guru ataukah orang tua, mengapa kemudian pertanyaan ini muncul, oleh karena sebagian dari orang tua memiliki asumsi bahwa pendidikan karakter adalah tanggung jawab guru, sebagian lainnya menyatakan itu menjadi tanggung jawab orang tua. Ada pula yang menyatakan guru dan orangtua masing-masing memiliki tanggung jawab terhadap pembentukan karakter anak.

Secara umum orang tua menyekolahkan anak mereka dengan harapan agar anak mereka memiliki pengetahuan, keterampilan serta perilaku yang terdidik. Demikian pula dengan harapan kurikulum 2013 yang mencanangkan 
pentingnya pendidikan karakter agar anak di masa yang akan datang mampu bersaing dan memiliki kemandirian dalam menghadapi kehidupannya. Ada kesenjangan proses penanaman karakter yang selama ini berlangsung. oleh karena beberapa orangtua lebih berharap kepada sekolah atau lembaga di mana anak-anak mereka menempuh pendidikan untuk mendidik anak-anak mereka dan seakan pelimpahan tugas mendidik ini sepenuhnya menjadi tanggung jawab pihak sekolah. Dengan adanya masa pandemik ini yang mengharuskan seluruh anak Indonesia melangsungkan proses pembelajarannya dari rumah maka secara otomatis sekolah dan guru tidak lagi menjadi faktor yang mendominasi anak dalam memperoleh pengetahuan, keterampilan dan pendidikan karakter. Maka kemudian orang tua serta lingkungan keluarga diharapkan mampu menjadi partner dalam proses pembelajaran tersebut. Sejalan dengan tuntunan ajaran agama Islam agar orang tua menjadi pendidik yang utama dan pertama bagi anak-anak mereka.

Karakter merupakan suatu sifat yang khas melekat pada diri seseorang yang dapat membedakan dirinya dengan yang lain. Karakter yang terbangun pada diri seseorang mengalami proses dalam jangka waktu yang relatif lama, karakter tidak terbangun seketika. Dalam proses pembentukan karakter bisa terjadi karena merupakan desain atau direncanakan dan juga memungkinkan terjadinya melalui proses yang tidak disengaja atau tidak terencana. Karena proses pembentukan karakter tidak semuanya hanya dibentuk di sekolah atau lembaga formal tertentu, tetapi pembentukan karakter pada seseorang mengalami proses pembentukan di mana dia tumbuh dan berkembang atau di tempat mana yang mendominasi dirinya selama proses tumbuh dan 
berkembangnya. Konsep baiti jannati dalam Islam menunjukkan bahwa betapa pentingnya peran orang tua serta keluarga dalam proses pembelajaran anak. Bahkan Islam menyebutkan bahwa seluruh rangkaian aktivitas kita dari bangun tidur hingga kembali tidur merupakan proses pembelajaran yang tidak pernah berhenti dikuatkan dengan salah satu dalil yang artinya "tuntutlah ilmu mulai dari ayunan sampai ke liang lahat."

Pembentukan karakter anak tidak boleh terjeda hanya karena adanya pandemik. Bahkan dengan kondisi ini orangtua serta keluarga dari peserta didik seharusnya memaksimalkan fungsinya dalam pembentukan karakter anak dan memaksimalkan fungsi rumah sebagai ruang belajar yang menyenangkan bagi anak-anaknya. Dalam pembentukan karakter anak selama anak belajar dari rumah dapat dilakukan beberapa trik yang antara lain, sebagai berikut:

1. Taat melaksanakan kegiatan ibadah

2. Rajin berdo'a

3. Memiliki konsep yang jelas tentang seluruh kegiatan anak.

4. Memiliki peraturan yang berlaku bagi seluruh anggota keluarga.

5. Menanamkan kedisiplinan selama melaksanakan kegiatan di rumah.

6. Setiap anggota keluarga memiliki tanggung jawab terhadap kebersihan, dan kenyamanan di rumah.

7. Menanamkan prinsip bahwa bekerja adalah bagian dari proses belajar.

8. Orang tua atau anggota keluarga yang lebih tua memberi kesempatan kepada anggota keluarga yang lebih mudah untuk dapat bertanggung jawab 
terhadap satu atau beberapa jenis pekerjaan sesuai dengan kapasitas anak.

9. Belajar dan menyelesaikan tugas dari sekolah

10. Memanfaatkan waktu istirahat sesuai porsinya. (saat jam tidur malam, istirahat siang dan waktu bersantai di sore hari)

11. Keluarga menyiapkan suasana rumah yang kondusif dan nyaman agar seluruh anggota keluarga dapat menyelesaikan setiap tugas dan tanggung jawabnya dengan nyaman.

12. Anggota keluarga yang lebih tua memberi contoh sikap santun, beretika atau berakhlakul karimah.

13. Anggota keluarga yang lebih tua membimbing yang lebih mudah dalam menyelesaikan suatu pekerjaan.

14. Memberi batasan durasi waktu kepada anak terhadap penggunaan HP android atau sejenisnya, dan menonton televisi secara konsisten.

15. Seluruh anggota keluarga menjalin komunikasi yang harmonis.

16. Seluruh anggota keluarga berperilaku positif

17. Orang Tua memberi dukungan terhadap kepatuhan pada aturan dalam rumah dan kegiatankegiatan positif anggota keluarga serta memberi reward.

18. Orangtua memberi sanksi terhadap anggota keluarga yang tidak patuh terhadap aturan dalam rumah.

Harapan kita, adalah terbangun kemitraan yang baik antara orangtua dan pihak sekolah serta masyarakat dalam pembentukan karakter anak. Guru menjalankan tugasnya 
sebagai pendidik, motivator, pembimbing dan sebagai pengawas. Sementara orang tua juga tetap menjalankan tugasnya sebagai pendidikan yang pertama dan utama bagi anak-anaknya. Demikian pula dengan masyarakat, dapat menyuguhkan suasana ruang belajar yang terbuka untuk setiap anak. Sehingga di manapun anak berada proses belajar dan pendidikan karakternya tetap berlangsung tanpa dibatasi oleh kondisi-kondisi yang tidak diharapkan atau kondisi yang tidak terduga. 


\section{Daftar Pustaka}

Aji. 2020. "Dampak Covid-19 pada Pendidikan di Indonesia:

Sekolah, Keterampilan, dan Proses Pembelajaran”. SALAM; Jurnal Sosial \& Budaya Syar-i FSH UIN Syarif Hidayatullah Jakarta Vol. 7 No. 5 (2020). Jakarta.

Kusuma, Darma, dkk. 2011, Pendidikan Karakter Kajian Teori dan Praktek di sekolah, Bandung: PT Remaja Rosdakarya.

Wyne dalam Musfah. 2011, Pendidikan karakter Sebuah Tawaran Model Pendidikan Holistik Integralistik, Jakarta: Prenada Media. 


\title{
PEMBELAJARAN DARING MELATIH KEMANDIRIAN DAN PENDEWASAAN PROSES BELAJAR MAHASISWA DI MASA PANDEMIK
}

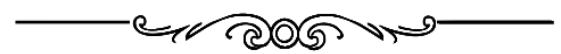

Yulianti Wulandari, SKM.,MARS ${ }^{23}$

\section{Dosen Prodi Ilmu Keperawatan, STIKes Awal Bros Batam}

\begin{abstract}
"Kelas daring ini dianggap praktis karena waktu yang tersisa bisa dipakai untuk belajar atau membuat kegiatan lain yang lebih berguna tanpa meninggalkan rumah."
\end{abstract} Pandemi Covid-19 melanda seantero dunia saat ini.
Banyak negara yang mempunyai kasus positif atas wabah tersebut. Dilaporkan dari portal World Healt Organisation (WHO), bahwa hingga Minggu, 7 Juni 2020, sebanyak 6.799.713 kasus positif dan 397.388 kasus kematian. Sementara di Indonesia pandemi ini telah

23Yulianti Wulandari, SKM.,MARS adalah seorang akademisi dan juga seorang Manager di sebuah Rumah Sakit Group Swasta terkenal di Indonesia. Dimana sebelum bergabung di dunia pendidikan sejak lulus Diploma Keperawatan SINT Carolus, Sarjana Kesehatan Masyarakat serta melanjutkan Pasca Sarjana di Universitas Indonesia dan sudah terjun di dunia perumahsakitan selama hampir 30 (tiga puluh) tahun yang digelutinya sampai dengan sekarang. Lahir pada tgl 11 Juli 1967 di Jakarta. Menyelesaikan pendidikan pascasarja sejak tahun 2000 penulis adalah dosen Pasien Safety dan K3 serta Informasi Keperawata. Saat ini penulis Saat ini penulis sedang mencoba melanjutkan pendidikan S3 di Universitas Borobudur dengan konsentrasi keperawatan sesuai program studi di STIKes Awal Bros Batam. Sekarang berdomisili di Komp Anggrek Mas 2 Blok E3 No 20 Batam-Kepulauan Riau. 
mengakibatkan 31.186 orang terdeteksi positif, 10.498 orang dinyatakan sembuh dan 1.851 orang meninggal dunia.

Seperti kita ketahui wabah COVID-19 merupakan penyakit yang berasal dari virus corona, virus tersebut diisukan berasal dari sebuah pasar tradisional hewan di Wuhan yang bernama Pasar Huanan, ibukota provinsi Hubei, China, dimana kasus pertama dilaporkan terjadi pada Desember tahun 2019 (Coronavirus Disease 2019). Penyebaran Covid-19 terjadi melalui kontak langsung dengan manusia yang telah positif terkena virus Corona dalam jarak yang cukup dekat, sehingga tetesan 'air liur' atau droplet secara tidak langsung menjadi faktor yang membuat manusia lain terpapar virus ini. Melihat dampak yang sangat serius mengakibatkan Organisasi Kesehatan Dunia atau World Health Organization (WHO) menyatakan bahwa, covid-19 ini merupakan pandemi global, karena meluasnya penyebaran virus tersebut ke berbagai belahan dunia dengan berbagai dampak yang dihasilkan dengan keberadaan pandemi ini.

Metode pembelajaran berbasis daring saat ini banyak dibantu dari berbagai platform media pembelajaran online yang dijadikan sebagai salah alat bantu dalam melaksanakan kegiatan belajar-mengajar yaitu Webinar, Zoom, Google Classroom, Google Meeting, Whatsapp Group, dan lain lain. Bisa dikatakan aplikasi Zoom ini jarang sekali mengalami kendala hingga berakibat down pada saat digunakan.

\section{Fungsi Aplikasi Zoom Meeting}

Zoom Meeting merupakan sebuah aplikasi video conference yang dikembangkan oleh perusahaan asal Amerika Serikat (Zoom Video Communications, Inc) yang dapat digunakan pada perangkat komputer, smartphone 
sampai sistem ruang. Untuk menikmati aplikasi Zoom Meeting cukup menginstall aplikasi client atau browser extention pada computer/laptop sedangkan pada smartphone bisa mendownload dan install aplikasi Android maupun iOS.

\section{Kelebihan dan Kekurangan Proses Pembelajaran Daring}

Kemajuan teknologi yang sangat pesat membuat kehidupan kita semakin mudah walau dengan jarak yang sangat jauh sekalipun. Akan tetapi tidak bisa kita pungkiri bahwa ada beberapa kelebihan dan kekurangan dengan belajar secara daring. Sehingga kita harus bisa mengantisipasi apabila kita tahu kelebihan dan kelemahan dari proses belajar secara daring tersebut.

Kelebihan belajar secara daring :

1. Waktu dan tempat yang fleksibel

Waktu dan tempat yang akan digunakan kelas kuliah secara daring dapat menyesuaikan dimana kita berada saat itu. Di dalam rumah, dosen dan mahasiswa dapat melakukan proses ini asal ada signal internet yang kuat.

2. Hemat waktu dan ekonomis

Dengan kelas daring kita tidak perlu waktu khusus untuk pergi kesatu tempat belum lagi bila ada kemacetan saat di perjalanan dan tidak perlu biaya alias ekonomis tidak membutuhkan ongkos untuk menaiki kendaraan agar bisa sampai ketempat tujuan.

3. Kuliah dari dalam negeri maupun luar negeri

Kelas daring ini bisa dilaksanakan kapan saja dimana saja serta dengan jarak yang tak ada batasnya. Bahkan apabila ada dosen tamu dari luar negeri pun bisa dilaksanakan perkuliahan tersebut. 
4. Bermodalkan laptop atau smartphone dan kuota internet

Dosen atau mahasiswa tinggal menentukan posisi yang nyaman untuk memberikan atau menerima serta menyimak materi maupun praktek secara daring hingga pertemuan berakhir.

5. Materi bisa di simpan

Dengan perkuliahan model daring maka perkuliahan yang dilaksanakan bisa dilakukan penyimpanan dan bisa dibuka lagi saat diperlukan atau bisa juga sebagai bahan evaluasi kelas daring nantinya.

6. Praktis

Kelas daring ini dianggap praktis karena waktu yang tersisa bisa dipakai untuk belajar atau membuat kegiatan lain yang lebih berguna tanpa meninggalkan rumah.

Kekurangan Belajar Secara Daring

1. Perbedaan waktu

Saat ada perkuliahan oleh dosen tamu dari luar negeri maka otomatis ada perbedaan waktu yang sangat significant.

2. Budget kuota internet

Kita juga harus bijak dalam menggunakan kuota internet, sering download gambar apalagi video membuat kuota internet habis. siasati dengan memilih mana yang perlu di download atau tidak dan mana yang lebih berguna.

3. Smartphone penuh notifikasi

Kadang kala kita tidak selalu memegang android, dimana kita baru ditinggal sedetik smartphone sudah penuh dengan notifikasi. Mau kita skip untuk tidak dibaca takut ada yang penting atau kita tidak up to date nantinya.

4. Smartphone cepat lowbat 
Penggunaan aplikasi yang banyak pada smartphone otomatis akan membuat baterai cepat lemah walaupun bisa discharge atau diisi kembali akan tetapi saat kita melakukan charge dan menggunakan smartphone akan membuatnya cepat rusak.

5. Ketergantungan terhadap smartphone

Seperti pepatah "dunia ada digenggaman kita" maka benar adanya bila kita tidak bisa jauh jauh dari handphone akibatnya kita tidak bisa hidup/kerja tanpa handphone.

6. Miscommunication

Kuliah daring juga menyebabkan miskomunikasi terlebih bila sinyal internet buruk, jadi kadang tidak bisa disalahkan bila apa yang diterima maha itu tidak 100\% . Untuk itu kita membutuhkan effort yang kuat saat kuliah daring.

7. Tidak fokus.

Tidak semua dosen atau mahasiswa memiliki ruangan yang nyaman untuk menyampaikan atau menerima materi kuliah.

\section{Permasalahan yang Terjadi Saat Kuliah Daring}

1. Permasalahan Dari sisi Dosen

Proses pembelajaran daring yang dilakukan di Indonesia sebenarnya tidak mudah dilakukan dimana dalam proses pelaksanaanya banyak sekali permasalahan yang menjadi dilema baik dari pendidik maupun mahasiswa itu sendiri. Dari sisi pendidik sebenarnya ini adalah tantangan karena seharusnya dosen harus mengikuti perkembangan zaman. Dan hal ini juga sangat membantu meningkatkan profesionalaitas dan mutu pendidikan karena sebenarnya dosen sudah memiliki alat teknologi sejenis smartphone atau laptop hanya pemanfaatannya belum dilaksanakan secara maksimal. Sampai akhirnya 
terjadi pandemic dan mengharuskan para dosen mampu menggunakan teknologi daring untuk sistem pengajaran/perkuliahan jarak jauh.

2. Permasalahan Dari Sisi Mahasiswa

Dalam pelaksanaan proses belajar daring dari rumah diberlakukan sejak Maret ternyata mahasiswa banyak yang belum siap. Dimana harapannya mahasiswa dapat belajar mandiri, bereksplorasi sendiri dan berkembang dalam lingkungannya., Tidak bisa dipungkiri mereka masih membutuhkan stimulus untuk melakukan itu, dimana reward dan punishment tetap berlaku walau pembelajaran dilakukan secara daring. Hal itu disebabkan kemandirian belajar dari mahasiswa banyak belum terbentuk. Kemandirian belajar adalah kondisi aktivitas belajar yang mandiri tidak tergantung pada orang lain, memiliki kemauan, inisiatif serta bertanggung jawab sendiri dalam menyelesaikan masalah belajarnya.

\section{Permasalahan dari sisi Orang tua}

Selain pendidik dan peserta didik dalam menjalankan proses daring ini juga diperlukan peran serta orang tua tentunya sebagai fungsi kontrol di lingkungan rumah. Walaupun perkuliahan daring sudah berjalan beberapa bulan, akan tetapi masih banyaknya keluhan dari orang tua karena dianggap kuliah daring ini merupakan beban tersendiri yang harus dijalani. Dimana orang tua harus menyiapkan alat perangkat yang bisa digunakan, karena tidak semua perangkat smartphone yang digunakan anaknya bisa digunakan. 


\section{Daftar Pustaka}

Anton Sukarno.(1999). Ciri-Ciri Kemandirian Belajar. Jakarta: Kencana Prenada Media.

Charismiadji.A. (2020, April 01). Mengelola Pembelajaran Daring Yang Efektif.

Jacob Utomo. (1980). Kemandirian Belajar Siswa Perlu Ditingkatkan. Jakarta: Bumi Aksara.

Kurtanto. (2017). Keefektifan Model Pembelajaran Daring. Journal Indonesian Language Education And Literature Vol. 3, No. 1, 99-109.

Mohamad Toha Anggoro, A.P. Hardhono,Tian Belawati, Dan Tri Darmayanti Tutorial Elektronik Melalui Internet Dan Fax-Internet, Jurnal Ptj-Ut, Volume 1.2., (Http://Www.Ut.Ic.Id)

Phillip Rekdale, Internet Dan Pendidikan, (Http://Pendidikan.Net)

Rosnida. (2007). Kemandirian Dalam Perilaku. Jakarta: Bumi Aksara

Sudirman Siahaan; E-Learning (Pembelajaran Elektronik) Sebagai Salah Satu Alternative Kegiatan Pembelajaran, (Http://Www.Depdiknas.Go.Id)

Setiawan, P. (2020). Pengertian E-learning Pengertian Elearning Menurut Para Ahli Karakteristik E-learning Manfaat E-learning.

Thursan Hakim. (2006). Mengatasi Rasa Tidak Percaya Diri. Jakarta: Puspa Swara.

Https://Covid19.Who.Int

Https://Www.Covid19.Go.Id 


\section{SEBUAH DIALOG: \\ PENDIDIKAN KARAKTER DAN \\ PEMBELAJARAN SEJARAH BERBASIS \\ DARING

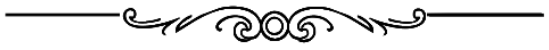

Aulia Novemy Dhita, M.Pd.24

Universitas Sriwijaya

"Meneladani nilai-nilai atau karakter yang dimiliki oleh para tokoh sejarah Indonesia merupakan modal dasar para pendidik dalam menginternalisasi pendidikan karakter."

$\mathrm{P}$ endidikan karakter merupakan amanah Undang-Undang terutama UU No. 20 Tahun 2003 tentang Sistem Pendidikan Nasional pasal 3 yang menjelaskan bahwa pendidikan nasional bertujuan untuk mengembangkan potensi peserta didik agar menjadi manusia yang beriman dan bertakwa kepada Tuhan Yang Maha Esa, berakhlak mulia, cakap, kreatif, mandiri dan menjadi warga negara yang demokratis serta bertanggung jawab. Terkait dengan hal tersebut, maka satuan pendidikan baik yang bersifat formal atau informal dan tingkat pendidikan pra sekolah hingga perguruan tinggi harus mewujudkan amanah

24Penulis lahir di Surabaya, 15 November 1989. Merupakan dosen Universitas Sriwijaya, Program Studi Pendidikan Sejarah pada Fakultas Keguruan dan Ilmu Pendidikan. Menyelesaikan gelar Sarjana di almamaternya, dan melanjutkan magister di Universitas Pendidikan Indonesia-Bandung. Hasil penelitian atau pemikiran penulis, banyak berkaitan dengan tema pendidikan sejarah dan ilmu sejarah. Beberapa karyanya dapat ditemukan di google scholar atau sejenisnya dan surat kabar lokal. 
konstitusi tersebut. Selain satuan pendidikan, keluarga dan masyarakat merupakan lingkungan yang berpengaruh terharap pembentukan karakter peserta didik. Sehingga ketiga unsur tersebut harus bahu membahu agar dapat menciptakan generasi Indonesia yang berkarakter untuk kepentingan dan kemajuan Indonesia.

Salah satu upaya yang dapat dilakukan satuan pendidikan dalam rangka penerapan pendidikan karakter adalah melalui kearifan lokal. Menurut Rahyono (2009: 11) kearifan lokal yang dimiliki oleh kelompok etnis tertentu merupakan hasil kecerdasan masyarakat yang diperoleh dari pengalaman kelompok etnis tersebut. Berangkat dari pengertian tersebut, setiap masyarakat memiliki kearifan lokal yang berbeda dan menjadi ciri khas suatu masyarakat. Hasil kecerdasan masyarakat tersebut jika dikonversikan dengan pendapat Koentjaraningrat merupakan bagian dari kebudayaan yang terdiri dari sistem bahasa, sistem pengetahuan, sistem sosial, sistem peralatan hidup dan teknologi, sistem mata pencaharian hidup serta sistem religi.

Internalisasi nilai-nilai yang terdapat pada kearifan lokal dapat diterapkan dalam pendidikan karakter. Dalam pembelajaran sejarah, hal ini sangat berkaitan dengan idealisme pembelajaran sejarah yang berkaitan dengan nasionalisme dan patriotisme serta karakter lainnya. Menurut Hariyono (2018: 5) dalam pembelajaran sejarah, pendidikan karakter berkaitan dengan kisah sejarah yang digunakan sebagai materi pembelajaran dan memanfaatkan beragam sarana belajar, sumber belajar, metode belajar hingga evaluasi belajar. Selain kedua aspek itu, pendidikan karakter dalam pembelajaran sejarah juga memandang penting posisi pendidik sebagai role model untuk melayani, memfasilitasi dan mendampingi proses belajarnya. Jika 
aspek-aspek tersebut dapat dipenuhi, maka pendidikan karakter mudah untuk diterima. Pendapat tersebut secara tidak langsung menguraikan bahwa pendidikan karakter tidak serta merta mengenai metodologi pembelajaran, tapi juga kepribadian pendidik. Artinya, pendidik harus lebih dulu menguasai bahkan 'menyukai' materi pembelajaran yang akan disampaikannya sehingga peserta didik dapat merasakan 'kenikmatan' belajar.

Pendidikan karakter dapat diterapkan melalui kearifan lokal dalam pembelajaran sejarah berbasis daring. Sebagai kota multikultur, Sumatera Selatan menyimpan budaya yang beragam salah satunya songket Palembang. Menurut Andaya dalam Purwanti dan Siregar (2016: 98) songket Palembang telah populer sejak tahun 1969 yaitu pada masa Kerajaan Palembang dan pada masa Kesultanan Palembang, jenis kain yang dibuat dengan cara ditenun dari benang emas dan perak ini merupakan kebanggaan para bangsawan. Proses menenun sangat rumit dan memerlukan sikap ulet dan sabar. Sikap-sikap tersebut perlu diteladani, ditengah perkembangan generasi saat ini yang ingin serba instan. Untuk menghasilkan songket berkualitas tentu melewati proses panjang, begitu pula bangsa ini, kemajuannya berada ditangan generasi yang tangguh.

Meneladani nilai-nilai atau karakter yang dimiliki oleh para tokoh sejarah Indonesia merupakan modal dasar para pendidik dalam menginternalisasi pendidikan karakter. Melalui kisah-kisah sejarah yang merupakan materi pembelajaran sejarah, pendidik menyampaikan sikap yang harus diteladani. Bagaimana melakukannya? memulainya dari sejarah lokal. Penerapan sejarah lokal dalam materi yang bersifat nasional merupakan bagian dari contextual learning. Misalnya, pada materi Proklamasi Kemerdekaan Indonesia, selain menguraikan mengenai Peristiwa 
Rengasdengklok hingga pengibaran bendera Merah Putih pada tanggal 17 Agustus 29145 di kediaman Soekarno, Jl. Pegangsaan Timur, perlu dijelaskan proses atau kondisi wilayah lain di Indonesia pasca proklamasi kemerdekaan Indonesia. Di Palembang, berita proklamasi kemerdekaan Indonesia pertama kali diterima oleh Mailan (seorang pemuda yang bekerja di Radio Domei). Berita tersebut, ia sampaikan kepada A.K. Gani sebagai tokoh perjuangan di Palembang. Namun demikian, A.K. Gani tidak langsung menyebarkan 'kabar baik' tersebut. Ada proses pertemuan dengan para tokoh perjuangan lain untuk memastikan kabar tersebut ditengah situasi kondisi di Palembang pada saat itu. Sikap yang dapat di teladani dari uraian tersebut adalah mencari kebenaran suatu informasi. Mailan bisa saja langsung menyebarkan informasi tersebut melalui radio. Namun ia lebih memiliki menyampaikannya kepada A.K. Gani. Sikap ini sangat perlu diterapkan, terutama pada kondisi saat ini, dimana informasi hoaks 'bertebaran dimana-mana'.

Lalu bagaimana tantangan pendidikan karakter dalam pembelajaran sejarah yang dilakukan secara daring? Metode pembelajaran ini merupakan program pendidikan yang telah diterapkan sebelum Pandemi Covid-19. Namun sejak penyebarannya yang kian masif, pembelajaran daring study form home diterapkan secara penuh pada tahun 2020. Bukan hanya di Indonesia, tapi seluruh negara di dunia. Pembelajaran daring merupakan salah satu tanda kemajuan teknologi. Menurut Nazerly dalam Purandina \& Winaya (2020: 273) pembelajaran daring memiliki keunggulan yaitu fleksibel (waktu dan tempat) serta dapat mengakses internet setiap waktu. Adapun kelemahan pembelajaran daring yaitu interaksi langsung terbatas dan bergantung pada internet. 
Pendapat tersebut diperkuat dari hasil penelitian yang dilakukan oleh Agusmanto Hutauruk dan Ropinus Sidabutar (2020: 49), problematika pembelajaran daring diantaranya keterbatasan jaringan internet dan pelayanan akademik oleh para dosen. Selain itu penelitian dari Asmuni (2020: 283-285) mendeskripsikan problematika pembelajaran daring yaitu peserta didik tidak dapat memahami materi secara komprehensif, kemampuan pendidik dalam mengelola teknologi yang digunakan dalam pembelajaran dan keterbatasan pendidik mengontrol saat pembelajaran berlangsung. Kendala yang dialami orang tua saat pembelajaran daring di rumah yaitu tidak dapat mendampingi anak mereka terutama bagi orang tua yang bekerja dan keterbatasan ekonomi untuk mendukung pembelajaran daring.

Berkaca dari uraian pendidikan karakter, melalui pembelajaran daring penerapannya juga dapat dimulai dari diri pendidik. Perlu dirancang pembelajaran sejarah yang jelas dan terarah serta menyesuaikan dengan metode pembelajaran daring. Pertama, merancang rencana pembelajaran. Termasuk sumber belajar, metode belajar, sarana belajar dan evaluasi serta tata tertib pembelajaran daring. Misalnya walau pembelajaran dilakukan secara virtual, pembelajaran daring tetap dilakukan tepat waktu, menyalakan kamera, menggunakan pakaian yang sopan, fokus (tidak melakukan kegiatan lainnya saat pembelajaran virtual). Kedua, kekuatan pembelajaran virtual terletak pada kepribadian pendidik termasuk kemampuannya dalam mengelola kelas secara virtual. Kepribadian yang berkarakter merupakan teladan paling mujarab terutama dalam pembelajaran daring. Beberapa kemampuan mengelola kelas virtual diantaranya, kemampuan komunikasi, mampu mencairkan suasana, menggunakan 
contoh yang konkrit dan lainnya. Terkait dengan kemampuan mengelola kelas, terdapat beberapa aplikasi elearning yang dapat digunakan diantaranya Google Classroom, Schoology, Moodle, Edlink, Quipper School dan lainnya. Dalam pembelajaran virtual, untuk memastikan peserta didik fokus dalam pembelajaran dapat menggunakan slido.com, Kahoot! atau Google Form dan lainnya.

Berbagai aplikasi tersebut sangat mudah digunakan untuk mendukung pembelajaran daring. Cara menggunakannya tersedia online sehingga dapat dipelajari kapan saja, baik secara mandiri atau berkelompok. Namun demikian, pada kenyataannya, masih perlu waktu untuk beradaptasi dengan berbagai aplikasi dan fitur-fiturnya. Serta yang paling penting yaitu 'kehadiran' pendidik dalam proses pembelajaran. Pada fase ini, pendidikan karakter lebih banyak dibangun melalui kepribadian pendidik. Peserta didik akan melihat dan merasakan bagaimana sikap guru atau dosen dalam 'melayani' selama proses pembelajaran. Itulah sebab, pendidik harus 'hadir'. Tentu akan berbeda, jika pembelajaran lebih banyak mengerjakan tugas dibandingkan 'kehadiran' pendidik dalam pembelajaran.

Dalam pembelajaran sejarah, materi pembelajaran mengandung nilai-nilai keteladanan yang harus diungkapkan bukan hanya oleh pendidik, namun juga peserta didik dan diterapkan dalam pembelajaran virtual. Kesadaran nilai-nilai luhur yang dimiliki oleh para tokoh bangsa, menghormati etnis lain dalam keragaman kearifan lokal tidak akan membuahkan hasil pada hari itu juga. Namun 'batu sekeras apapun, jika ditetesi air terus menerus, akan berlubang juga'. Dialog ini ditutup dengan refleksi bahwa pendidikan karakter must go on. Dalam 
pembelajaran sejarah, pendidikan karakter dapat diterapkan dengan menggunakan pendekatan kearifan lokal dan sejarah lokal. Lebih dari itu pendekatan tersebut harus beriringan dengan kepribadian pendidik dalam 'melayani' peserta didik dan 'hadir' selama proses pembelajaran daring. 


\section{Daftar Pustaka}

Asmuni. 2020. Problematika Pembelajaran Daring di Masa Pandemi Covid-19 dan Solusi Pemecahannya. Jurnal

Pedagogy: Jurnal Penelitian dan Pengembangan Pendidikan. $\quad 7(4), \quad 281-288 . \quad$ Doi: 10.33394/jp.v7i4.2941

Hariyono. 2018. Pendidikan Sejarah dan Karakter Bangsa: Sebuah Pengantar Dialog. Jurnal Pendidikan Sejarah Indonesia. 1(1), 1-22. Doi: 10.17977/um033v1i12018001

Hutauruk, A. dan Sidabutar, R. 2020. Kendala Pembelajaran Daring Selama Pandemi di Kalangan Mahasiswa Pendidikan Matematika: Kajian Kualitatif Deskripti. SEPREN: Journal of Mathematics Education and Applied. Vol. 02, No.01, 45-51. Doi: 10.36655/sepren.v2i1.364.

Purandina, I. P. Y. dan Winaya, I. M. A. 2020. Pendidikan Karakter di Lingkungan Keluarga Selama Pembelajaran Jarak Jauh pada Masa Pandemi COVID-19. Cetta: Jurnal Ilmu Pendidikan. 3(2), 270290. Doi: $10.37329 /$ cetta.v3i2.454

Purwanti, R. dan Siregar, S.M. 2016. Sejarah Songket Berdasarkan Data Arkeologi. Sidhhayatra. 21(2), 97-106.

Rahyono, FX. 2009. Kearifan Budaya dalam Kata. Jakarta: Wedatama Widyasastra. 


\title{
MEMBANGUN LITERASI MEMBACA \\ MAHASISWA MELALUI PENUGASAN \\ STUDI KASUS DAN INFOGRAFIS PADA \\ PEMBELAJARAN JARAK JAUH
}

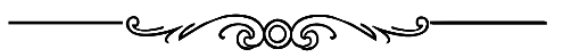

\section{Rahmadyah Kusuma Putri, M.Pd25 \\ Universitas Palangka Raya}

\begin{abstract}
"Pembelajaran jarak jauh yang dilakukan pada mahasiswa "angkatan covid" ini semestinya memberi bekal lebih banyak untuk menghadapi perubahan masa mendatang yang tidak dapat diprediksi."
\end{abstract}

Penghargaan tertinggi bagi seorang dosen bukan hanya gelar akademik dan serentetan karya tulis dengan indeks sitasi tinggi, namun dapat menghasilkan mahasiswa yang survive di tengah gelombang kemajuan zaman. Tentu bukan hal mudah untuk mewujudkan "produk" sesuai dengan visi misi lembaga pendidikan yang mayoritas berorientasi global. Apalagi disaat pandemi dan pembelajaran dilakukan secara jarak jauh. Motivasi untuk memenuhi target tersebut seolah ikut terisolasi dan menunggu nanti.

25Penulis lahir di Medan, 07 November 1993, menyelesaikan gelar Sarjana Pendidikan Biologi di Universitas Negeri Medan (2011) dan Magister Pendidikan Biologi di Universitas Negeri Malang (2018). Penulis adalah dosen di Program Studi Pendidikan Biologi Universitas Palangka Raya, Kalimantan Tengah. Dapat dihubungi melalui email: rahmadyahkusumaputri@fkip.upr.ac.id 
Kebanyakan dosen masih mengikuti arus strategi pembelajaran yang umum digunakan. Trend penggunaan video conference agaknya dianggap sesuai untuk segala kondisi karena mampu mewadahi interaksi tatap muka real time. Namun tidak jarang yang terjadi justru komunikasi satu arah, yaitu mahasiswa tidak mengaktifkan kamera dan audionya, sementara dosen asyik sendiri dengan materi ajar. Lantas tujuan pembelajaran dianggap tuntas dengan berakhirnya sesi 100 menit tersebut.

Selain itu, adapula pembelajaran menggunakan teknologi bersifat asynchronous, seperti LMS, google classroom dan whatsapp sebagai media interaksi antara dosen-mahasiswa-materi ajar yang dinilai cukup efektif untuk penugasan. Namun upaya tersebut masih membutuhkan penyesuaian terhadap jenis tugas yang diberikan, mengingat kebiasaan copy paste mahasiswa menyasar di segala jenis pembelajaran, baik luring maupun daring, tatap muka maupun jarak jauh dan materi sulit maupun mudah.

Pembelajaran jarak jauh yang dilakukan pada mahasiswa "angkatan covid" ini semestinya memberi bekal lebih banyak untuk menghadapi perubahan masa mendatang yang tidak dapat diprediksi. Satu sisi, pembiasaan penggunaan teknologi dalam pembelajaran sudah semakin baik. Di sisi lain, harus diimbangi dengan penguatan keterampilan, bukan hanya pengetahuan. Jika siswa sekolah dasar dan menengah tengah bersiap dengan literasi membaca dan numerik dalam Asesmen Kompetensi Minimumnya, maka mahasiswa juga sebaiknya bersiap untuk menjadi stakeholder dengan penguasaan literasi yang mumpuni, salah satunya adalah literasi membaca. 


\section{Pentingnya Literasi Membaca bagi Mahasiswa}

Mahasiswa sebagai akademisi tentu tidak dapat lepas dari aktivitas membaca, seperti membaca artikel jurnal dan materi kuliah. Literasi membaca merupakan pondasi pembentuk keterampilan abad 21 yang dikenal dengan istilah "The 4Cs", yaitu communication, collaboration, critical thinking, dan creativity (Partnership for 21st Century Skills, 2008). Melihat keterkaitannya dengan keterampilan abad 21, maka dapat diartikan bahwa tanpa keterampilan lliterasi membaca yang baik, manusia tidak akan mampu beradaptasi di abad 21. Literasi membaca bukan sekedar dapat membaca, namun mampu memahami, mengevaluasi, merefleksikan, menarik kesimpulan dan menggunakan informasi yang diperoleh.

Berdasarkan penggolongan tingkat kemampuan membaca menurut Chall (1983), kemampuan membaca mahasiswa diharapkan berada dalam tingkatan kelima (Construction and reconstruction). Pada tingkat tersebut, pembaca dianggap mampu mengkonstruk pemahaman melalui proses analisis dan sintesis informasi dari sumber bacaan. Wandell \& Le (2017) pada penelitiannya tentang cara kerja otak dalam proses membaca, membuktikan bahwa membaca mengaktifkan dan menghubungkan sel saraf visual dan auditori dengan otak bagian depan (frontal) yang berperan dalam mengandalikan bahasa dan fungsi intelektual. Oleh karena itu, kemampuan memahami bacaan sangat penting bagi mahasiswa dalam meningkatkan proses berpikir, sehingga dapat mendukung keterampilan abad 21 .

Ada tiga faktor yang mempengaruhi literasi membaca, yaitu faktor teks, faktor tugas dan faktor pembaca (OECD, 2019). Faktor teks adalah format teks, bahasa yang digunakan dalam teks dan jumlah halaman. Faktor tugas adalah tujuan membaca teks dan keterampilan berpikir. 
Faktor pembaca adalah motivasi, kedekatan pengalaman pembaca dengan teks dan kemampuan membaca. Ketiga faktor tersebut menjadi pertimbangan dalam menentukan strategi pembelajaran untuk membangun literasi membaca mahasiswa.

\section{Penugasan Studi Kasus dan Infografis}

Studi kasus merupakan salah satu strategi pembelajaran yang disarankan pada kebijakan Kampus Merdeka. Studi kasus dilakukan dengan cara melibatkan mahasiswa secara aktif dalam memecahkan permasalahan kontekstual dengan mengedepankan teori - teori ilmu pengetahuan. Sebagai contoh, penerapan studi kasus dilakukan pada mata kuliah Fisiologi Tumbuhan di Program Studi Pendidikan Biologi Universitas Palangka Raya tahun 2021. Mahasiswa diberikan sebuah cuplikan video narasi tentang kekeringan di Likotuden, Flores Timur. Video tersebut mendeskripsikan bahwa hanya tanaman sorgum yang dapat tumbuh di daerah Likotuden.

Selanjutnya mahasiswa diarahkan untuk menganalisis permasalahan yang dihadapi masyarakat Likotuden. Sehingga muncul pertanyaan: Mengapa sorgum dapat beradaptasi di lingkungan kering? Dan Alternatif tanaman apa saja yang dapat tumbuh di daerah kering? Pertanyaan tersebut dibentuk secara mandiri oleh mahasiswa sebagai hasil dari penelaahan terhadap video. Adanya pertanyaan yang akan dijawab dan permasalahan yang akan dipecahkan, mendorong mahasiswa untuk membaca artikel jurnal dengan kata kunci: tanaman C3, C4 dan CAM, peran air untuk tanaman, efek kekeringan pada tanaman dan nutrisi pada tanah kering. Mahasiswa aktif melakukan penyaringan informasi yang sesuai dan dibutuhkan. Secara tidak langsung, kegiatan ini telah membangun literasi membaca mahasiswa. Untuk mengevaluasi literasi 
membaca mahasiswa, dilakukan dalam bentuk penugasan infografis sebagai output dari studi kasus (Gambar 1).

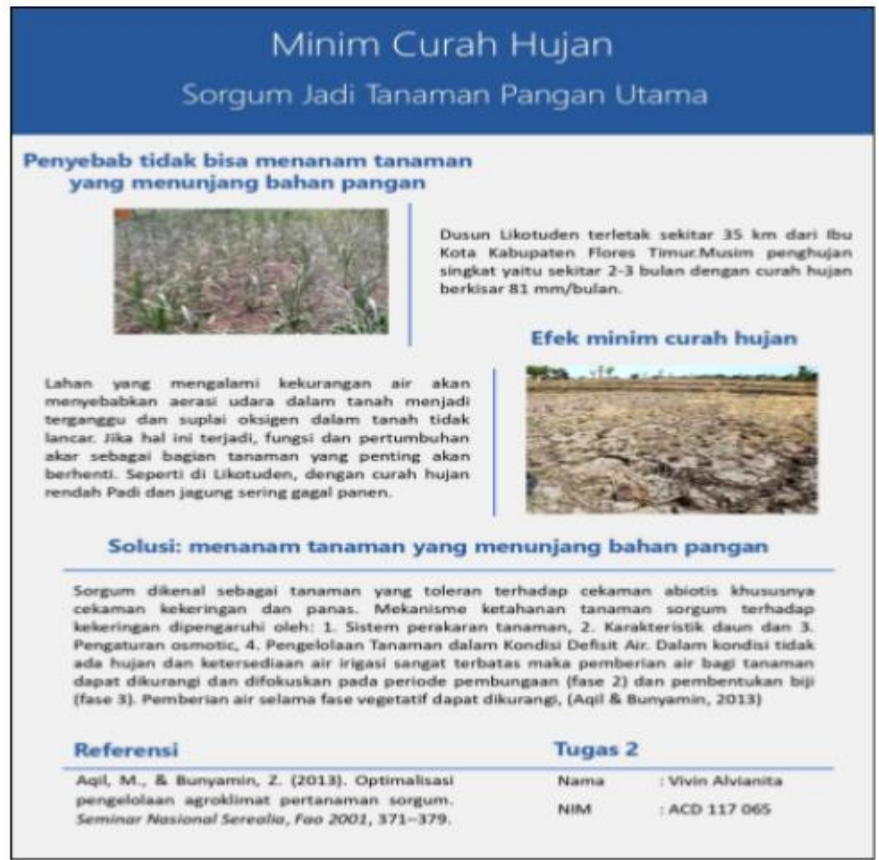

Gambar 1. Contoh Infografis untuk Studi Kasus pada Mata Kuliah Fisiologi Tumbuhan

Infografis menunjukkan pemahaman mahasiswa terhadap artikel jurnal sebagai referensi dalam memecahkan permasalahan. Infografis dipilih sebagai output studi kasus karena mampu memvisualisasikan ide mahasiswa secara jelas dan lebih ringkas. Infografis tersebut memuat komponen: 1) permasalahan, 2) efek fisiologis tumbuhan terhadap permasalahan yang terjadi, 3) solusi atau pemecahan masalah ditinjau dari teori fisiologi tumbuhan. Pada Gambar 1, ketiga komponen ini dijelaskan secara induktif-deduktif sesuai dengan proses berpikir mahasiswa. Melalui kegiatan membaca artikel jurnal dan 
menuliskan solusi permasalahan dalam bentuk infografis, diharapkan mahasiswa mampu memahami berbagai konsep fisiologi tumbuhan sekaligus membangun literasi membaca. Bentuk perubahan strategi pembelajaran telah membuktikan bahwa zaman bersifat dinamis dan memaksa dunia pendidikan untuk lebih adaptif agar dapat bertahan.* 


\section{Daftar Pustaka}

Chall, Jeanne. S. 1983. Stage of Reading Development. New York: McGraw-Hill Book Company

OECD. 2019. PISA 2018 Assessment and Analytical Framework.Paris: OECD Publishing

Partnership for 21st Century Skills. 2008. 21st Century Skills, Education \& Competiveness; A Resource and Policy Guide. Diakses melalui www.21stcenturyskills.org

Wandell, Brian. A. and Le, Rosemary K. 2017. Diagnosing The Neural Circuity of Reading. Neuron, Vol 96(2) :298-311. 


\title{
PERSEPSI DAN EKSPEKTASI PEMBELAJARAN JARAK JAUH (PJJ) DI ERA WABAH PANDEMI COVID-19
}

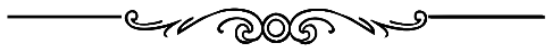 \\ Abdul Khamid, M.Pd26 \\ Institut Agama Islam Negeri Salatiga
}

"Wabah covid-19 ini pastinya memberikan sebuah dampak yang cukup signifikan terhadap keberlangsungan dan proses pelaksanaan pembelajaran."

unia kini sedang dilanda wabah corona Virus Disease
(covid-19). Virus mematikan yang pertama kali muncul di kota Wuhan, Cina, ini menyebar ke lebih dari 200 Negara di seluruh dunia, termasuk salah satunya adalah Negara Kesatuan Republik Indonesia yang mayoritas warganya beragama Islam. (Wachyudi Achmad, 2020).

Perjuangan pemerintah Indonesia dan semua elemen masyarakat masih digencarkan sampai saat ini dalam rangka memerangi merebaknya virus covid-19, kemunculan virus mematikan ini membuat ramai diseluruh masyarakat Indonesia bahkah dunia, berbagai media cetak maupun online setiap harinya memberitakan virus

26Penulis lahir di Grobogan, 25 Juni 1994. Penulis menyelesaikan Pendidikan sarjana Pendidikan Agama Islam IAIN Salatiga (2017). Kemudian melanjutkan ke jenjang Magister Pendidikan Agama Islam IAIN Salatiga lulus Tahun (2019). Saat ini penulis tercatat sebagai dosen aktif di IAIN Salatiga, selain dikampus penulis juga mengajar di salah satu Madrasah Tsanawiyah Swasta dan pengajar di salah satu Pondok Pesantren yang berada di Kabupaten Semarang. 
mematikan tersebut, melihat kegaganasan virus tersebut membuat berbagai kegiatan lumpuh, mulai dari kegiatan perekonomian, kegiatan transportasi, kegiatan pendidikan, dan kegiatan lainnya pun merasakan dampak akan adanya virus covid-19.

Peranan pemerintah untuk memutus rantai penyebaran covid-19 selalu dilaksanakan mulai dari pemberhentian sementara pembelajaran tatap muka digantikan dengan pembelajaran daring dengan skala pemanfaatan perkembangan teknologi internet yang kita ketahuai saat ini serba berkemajuan, pemberlakuan PSBB mulai dari skala kecil sampai PSBB dengan skala besar di laksanakan guna menekan angka peningkatan penderitaan covid-19, selain itu peranan masyarakatpun diperlukan dalam ikut serta mengkampayekan 5M (memakai masker, mencuci tangan, menjahui kerumunan, menjaga jarak, dan membatasi mobilitas). Wabah covid-19 ini pastinya memberikan sebuah dampak yang cukup signifikan terhadap keberlangsungan dan proses pelaksanaan pembelajaran. Kita ketahui bersama keberlangsungan pembelajaran dilakukan secara tatap muka di sebuah ruangan kelas, kini semua pembelajaran dilaksanakan dalam jaringan (daring). Pembelajaran seperti ini pada awalnya tidaklah dikehendaki oleh siapapun, namun dengan adanya wabah ini semua orang harus menyadari dan ikut melaksanakan pembelajaran demikian ini. (Rahmat Rifai dkk, 2020).

Berbekal uraian diatas dalam tulisan ini ingin mencoba menggali pelaksanaan pembelajaran jarak jauh yang kita ketahui bersama sudah berjalan selama adanya wabah pandemi covid-19. Solusi ataupun alternatif apa saja yang menunjang selama pembelajaran jarak jauh dan bagaimana persepsi dan ekspektasi mahasiswa PAI tentang 
pelaksanaan pembelajaran jarak jauh selama wabah pandemi covid-19.

\section{Bagian Solusi di Tengah Wabah Pandemi Covid-19 dengan Pembelajaran Jarak Jauh (PJJ)}

Situasi saat ini kita ketahui bersama menuntut kita harus serba sabar dalam segala bidang aktifitas, mengingat situasi saat ini semua kegiatan terbatasi oleh beberapa peraturan dari pemerintah, seperti dalam bidang pendidikan pun kita ketahui bersama merasakan dampak tersebut pembelajaran yang semula tatap muka kini semuanya diperhentikan dan di alihkan dengan pembelajaran dengan pemanfaatan perkembangan teknologi, semua aturan itu dikeluarkan demi terciptanya situasi masyarakat yang aman dari jangkitan wabah mematikan yaitu covid-19.

Dengan adanya wabah pandemi covid-19 ini, semua kegiatan wabilkhusus dunia pendidikan harus bertranformasi mengikuti perkembangan teknologi, menghadapi pembelajaran seperti ini perlunya kesiapan dan pemahaman bersama anatara pengajar dan yang di ajar guna merasakan kenyamanan bersama dalam proses pembelajaran jarak jauh dan tetap tersampaikannya materi dengan baik. Namun dalam situasi saat ini dibutuhkan solusi yang solutif di tengah-tengah wabah pandemi, yaitu dengan pemanfaatan beberapa perkembangan teknologi yang saat ini menjamur menawarkan beberapa solusi dalam pembelajaran jarak jauh. Dengan berbagai keterbatasan dan perlunya langkah awal guna tetap tersampaikannya materi dengan baik, maka guru/dosen mengambil beberapa langkah pemanfaatan teknologi jejaringan internet guna memberikan solusi di tengah-tengah merebaknya wabah pandemi. Sulusi solutif di tengah pandemi covid-19 yang dibawakan beberapa pengajar menggunakan beberapa 
aplikasi Online pembelajaran jarak jauh diantaranya: Whasapp Grub, Zoom Meeting, Google Meet, Goole Froms, Youtube PPT, dan E-elerning.

Berbekal dengan beberapa Aplikasi Online tersebut pembelajaran di tengah wabah pandemi tetap tersampaikan dengan baik. Dengan demikian tujuh aplikasi yang sering digunakan ini menjadikan sebagian solusi sementara yang cukup baik dalam pembelajaran jarak jauh serta menunjang dan hak-hak sebagai mahasiswa tetap terpenuhi mendapatkan pembelajaran sesuai dengan materi-materi yang sudah ditentukan di awal kontrak perkuliahan, sosuli ini cukup bagus untuk di terapkan disaat semua kampus diliburkan sebagai mahasiswa tetap mendapatkan pelayanan pengajaran melalui berbagai Aplikasi Online, karna pada dasarnya semua demi kebaikan bersama di tengah-tengah krisis kesehatan adanya wabah pandemi covid-19.

\section{Persepsi dan Ekspektasi Mahasiswa dengan adanya Pembelajaran Jarak Jauh (PJJ) di Masa Pandemi Covid-} 19

Berangkat dari adanya wabah pandemi covid-19, salah satu wabah yang menakutkan dan mematikan membuat peran pendidikan berubah total dari tatap muka beralih PJJ, sesuatu yang baru yang belum pernah dilakukan khusunya pembelajaran penuh menggunkan jejaringan internet secara tidak tatap muka, sehingga dalam hal ini menemukan beberapa pro dan kontra, dan menimbulkan persepsi dan ekspektasi yang sangat beragam menurut beberapa mahasiswa.

Tulisan ini berangkat dari penulis di tengah-tengah mengajar bertanya kepada beberapa mahasiswa wabilkhusus mahasiswa PAI selama pembelajaran kurang lebih 2 Semester selama pandemi covid-19, bagaimana 
dosen memberikan materi melalui online. Dan dengan adanya fenomena pembelajaran jarak jauh yang cukup baru ini, bagaimana persepsi atau pandangan mahasiswa dalam hal pemebelajaran online. dengan adanya pembelajaran jarak jauh ini sangatlah beraagam persepsi-persepsi mahasiswa yang muncul salah satunya, pertama, pada dasarnya pembelajaran PJJ sebelumnya banyak yang tidak mengindahkan dan kurang memberikan semangat dalam pembelajaran, tetapi hal ini semakin lama semakin sadar bahwasannya ini untuk kebaikan bersama. Kedua, disisi yang lain pembelajaran PJJ sangatlah baru dan memberikan dorongan kepada mahasiswa untuk lebih mengenal pemanfaatan teknologi yang berkembang saat ini. Ketiga, pembelajaran jarak jauh berjalan cukup lancar dan memuaskan walaupun ada beberapa kendala yang dialami oleh dosen dan mahasiswa dikarenakan memang ini kali pertama adanya pelaksanaan pembelajaran dengan sistem online. Keempat, pembelajaran jarak jauh bisa berjalan dengan baik, namun kami (Mahasiswa) terkadang masih didapati kendala adanya sinyal, sehingga sering ketinggalan materi dalam perkuliahan. Kelima, pembelajaran jarak jauh efektif digunakan ditengah-tengah wabah pandemi, mengingat masih bahayanya wabah tersebut, dengan adanya pembelajaran jarak jauh menjadikan kita (Mahasiswa) yang awalnya gaptek dapat meningkatkan semangat belajar mengikuti perkembangan teknologi. Keenam, jika di Tanya efektif tidaknya sebenarnya masih didapati kurang dibandingkan secara langsung tatap muka, namun dimasa pandemi covid-19 memang lebih aman diberlakukan pembelajaran jarak jauh guna menjaga kebaikan semuanya, sehingga segera terputus rantai penyebaran virus covid-19. 
Dengan demikian persepsi mahasiswa PAI dalam pembelajaran jarak jauh sangatlah beragam, semuanya itu dirasakan awal-awal yang kurang menyenangkan dibandingkan dengan pembelajaran tatap muka, namun setelah dikaji dan dilaksanakan secara perlahan semua bisa menerima dan memahami semua dilaksanakan demi kebaikan dan kesehatan semuanya, sehingga segera terputus rantai penyebaran virus covid-19 yang sudah lumayan lama menghantui di bumi Nusantara.

Selain persepsi yang disampaikan oleh mahasiswa PAI, mereka juga mengemukakan keinginan atau ekspektasinya guna berjalannya pembelajaran jarak jauh tetap berjalan dengan baik dan materi anatara dosen dengan mahasiswa dapat dipahami secara menyeluruh. Arti kata eskpektasi itu sendiri berasal dari bahasa Inggris "expectation" yang artinya harapan (Ayi Sobarna, 2005). Dalam hal ini mahasiswa mempunyai harapan dalam masa pembelajaran jarak jauh di era wabah pandemi covid-19 ini diantaranya: pertama, berlakunya pembelajaran jarak jauh kami (Mahasiswa) berharap adanya fasilitas tambahan yang diberikan dari pihak kampus, terkusus mahasiswa akhir mendapatkan pelayanan yang lebih guna mempercepat penyelesaian tugas akhir. Kedua, kuota tidak bisa kita (Mahasiswa) pungkiri dengan adanya pembelajaran jarak jauh menguras banyak kuota, dengan demikian perlunya penambahan subsidi kuota kepada mahasiswa. Ketiga, pembelajaran jarak jauh terkadang mahasiswa terkendala adanya sinyal yang kurang mendukung, dengan demikian mohon lebih sabar lagi untuk para pengajar manakala masih didapati mahasiswa yang kurang jelas dapat diperjelas kembali materinya. Keempat, adanya wabah pandemi, pembelajaran jarak jauh mengajak kepada semuaya untuk tanggap dalam situasi apapun penguatan 
pemanfaatn teknologi dalam pembelajaran meningkatkan mutu pembelajaran terkhusus pembelajaran PAI.

Dengan demikian harapan ataupun ekspektasi mahasiswa PAI di tengah-tengah pembelajaran jarak jauh ini mempunyai beberapa harapan sehingga dengan adanaya harapan tersebut dapat tersampaikan dan terealisasikan sehingga tetap berjalannya informasi dengan baik antara pengajar dan yang di ajar guna menuju pembelajaran yang tetap tersampaikan materinya dalam kondisi apaupun tetap harus berlangsungnya sistem pendidikan. 


\section{Daftar Pustaka}

Achmad Wachyudi. (2020) "Peran dan Tantangan Pendidikan Agama Islam di Era Pandemi Covid-19 pada Lingkungan Keluarga".JIE: Journal Of Islamic Education. Vol. 5 No. 2. Diakses di http://www.ejournal.stitmuhbangil.ac.id/ index.php/jie/ artcle/view/188

Ani Sobarna. (2005) "Ekspektasi Mahasiswa Unisba Terhadap Kuliah Pendidikan Agama Islam Persepetif Psikologi Eksistensial". Mimbar: Jurnal Sosial dan Pembangunan. Vol. XXI No. 4. Diakses di http://ejournal.unisba.ac.id/ index.php/mimbar/ article/view/194/pdf

Lubis Rifai Rahmad dkk. (2020) "Alternatif Startegi Pembelajaran Selama Pandemi Covi-19 Di STAI Sumatra Medan". Ansiru: Jurnal PAI. Vol. 4 No. 1. Diakses di http://www.jurnal.unisnu.ac.id 


\section{WADAH OLAHRAGA REKREASI NAGARI PAUAH LUBUK SIKAPING}

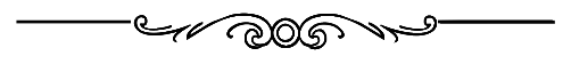

Prima Nanda, S.Pd., M.Pd.27

\section{SMA Negeri 2 Lubuk Sikaping, Pasaman, Sumatera Barat}

"Nagari Pauah merupakan salah satu nagari yang memiliki wadah yang sangat mendukung dalam pengembangan olahraga rekreasi."

$S_{\text {meningkat karena kurang olahraga dan aktivitas fisik, }}^{\text {aat ini, masalah kesehatan pada individu sedang }}$ seperti mesin melakukan sebagian besar pekerjaan, yang membuat aktivitas tubuh penting secara individual. Olahraga saat ini menjadi sebuah trend atau gaya hidup bagi sebagian masyarakat umum, bahkan hingga menjadi sebuah kebutuhan mendasar dalam hidup. Olahraga menjadi kebutuhan yang sangat penting karena tidak terlepas dari kebutuhan mendasar dalam melaksanakan aktivitas gerak sehari-hari. Secara sederhana olahraga dapat dilakukan oleh siapapun, kapanpun, dimanapun, tanpa memandang dan membedakan jenis kelamin, suku, ras, dan lain sebagainya.

27Penulis lahir di Lubuk Sikaping, 11 Desember 1991, penulis merupakan Guru PJOK di SMA Negeri 2 Lubuk Sikaping, Kabupaten Pasaman, penulis menyelesaikan gelar Sarjana Pendidikan Jurusan Pendidikan Kepelatihan Olahraga di Universitas Negeri Medan (2015), selanjutnya menyelesaikan gelar Magister Pendidikan, Program Studi Pendidikan Olahraga di Universitas Negeri Medan (2019) 
Mengacu pada Undang-Undang Sistem Keolahragaan Nasional Nomor 3 tahun 2005 Bab II pasal 4 menetapkan bahwa keolahragaan nasional bertujuan memelihara dan meningkatkan kesehatan, kebugaran, prestasi, kualitas manusia, menanamkan nilai moral dan akhlak mulia, sportivitas, disiplin, mempererat dan membina persatuan dan kesatuan bangsa, memperkokoh ketahanan nasional, serta mengangkat harkat, martabat, dan kehormatan bangsa. Pentingnya masyarakat menjadikan olahraga sebagai kebutuhan yang mendasar dengan tujuan meningkatkan kualitas sumber daya manusia. Olahraga rekreasi adalah olahraga yang dilakukan oleh masyarakat dengan kegemaran dan kemampuan yang tumbuh dan berkembang sesuai dengan kondisi dan nilai budaya masyarakat setempat untuk kesehatan, kebugaran dan kegembiraan. Hal ini sejalan dengan pasal 19 Bab VI UU Nomor 3 Tahun 2005 dinyatakan bahwa "olahraga rekreasi bertujuan untuk memperoleh kesehatan, kebugaran jasmani dan kegembiraan, membangun hubungan sosial dan atau melestarikan dan meningkatkan kekayaan budaya daerah dan nasional". Selanjutnya dinyatakan bahwa pemerintah daerah dan masyarakat berkewajiban menggali, mengembangkan dan memajukan olahraga rekreasi.

Olahraga telah dijadikan sebagai gerakan nasional dan merupakan implementasi dari pembangunan olahraga di Indonesia. Sejalan dengan itu, maka dicetuskanlah slogan "Tiada Hari Tanpa Olahraga" dengan harapan olahraga dapat tumbuh dan mengakar dalam kehidupan sehari-hari masyarakat disegala lapisan, mulai dari perkotaan sampai ke pedesaan. Ketika olahraga telah menjadi sebuah kebutuhan setiap orang dalam hidupnya maka timbulah sebuah permasalahan yaitu kebutuhan akan fasilitas yang bisa menunjang aktivitas olahraga. Demi kenyamanan dan 
kelancaran dalam melakukan aktivitas olahraga tersebut maka diperlukan pula fasilitas yang baik dan memenuhi standar keolahragaan. Dalam hal ini Pemerintah sebagai pembuat kebijakan mempunyai kewajiban dan tanggungjawab untuk memenuhi kebutuhan fasilitas tersebut sebagaimana yang diamanatkan Undang-Undang Sistem Keolahragaan Nasional Nomor 3 Tahun 2005.

Nagari Pauah merupakan salah satu nagari yang memiliki wadah yang sangat mendukung dalam pengembangan olahraga rekreasi. Nagari Pauah merupakan center dari pusat pemerintahan di Kecamatan Lubuk Sikaping Kabupaten Pasaman. Nagari Pauah memiliki wadah yang cukup berpeluang untuk pengembangan olahraga rekreasi. Pemerintah sangat perlu memperhatikan peluang mengingat pentingnya olahraga rekreasi untuk pembangunan kualitas sumber daya manusia dan tidak menutup kemungkinan pada peningkatan perekonomian serta eksistensi daerah dimata masyarakat luar. Nagari Pauah memiliki banyak wadah dan budaya aktivitas masyarakat yang saat ini sudah mulai hilang dikalangan masyarakat. Dapat dibuktikan bahwa banyaknya tempattempat yang yang memungkinkan adanya aktivitas olahraga tetapi tidak manfaatkan sebagai wadah aktivitas olahraga masyarakat. Banyaknya aktivitas permainan masyarakat yang sudah ditinggalkan dan memiliki nilai yang bermanfaat dalam peningkatan kualitas diri masyarakat. Untuk itu pada penulisan ini penulis bertekad memberikan pemahaman dan pandangan terhadap wadah olahraga rekreasi yang berpeluang dalam pembangunan kualitas sumber daya manusia maupun meningkatkan perekonomian pemerintah maupun masyarakat.

Batang Sumpu di Nagari Pauah yang memiliki area jalur sepanjang $\pm 1 \mathrm{KM}$ yang bisa digunakan masyarakat 
untuk beraktivitas olahraga. Namun saat ini wadah tersebut masih belum dimanfaatkan sebagai wadah beraktivitas olahraga. Batang sumpu juga memiliki aliran air yang tidak terlalu deras, hal ini juga dapat dimanfaatkan sebagai wadah olahraga rekreasi air dan ini dapat mengundang wisatawan untuk datang menyaksikan aktivitas budaya permainan air masyarakat seperti lomba babenen, lomba rakik batang pisang. Batang Sumpu juga memiliki lapangan yang cukup luas dan dapat dimanfaatkan untuk aktivitas olahraga rekreasi seperti bermain layang-layang bisa dilakukan acara tahunan. Batang sumpu dikelilingi dengan lahan persawahan ini juga dapat dimanfaatkan sebagai wadah festival mairiak disepanjang jalur batang sumpu. Jika pemerintah dapat memberikan perhatian khusus dalam pengembangan olahraga rekreasi maka dapat memberikan manfaat bagi baik dalam meningkatkan kualitas dan perekonomian masyarakat maupun pemerintah daerah.

Bukik ketek dilubuk sikaping sebagai wadah perkemahan dan aktivitas down hill run. Perkemahan dapat dimanfaatkan oleh sekolah sebagai aktivitas pramuka yang saat ini merupakan anjuran dalam kurikulum K13 sebagai aktivitas ekstrakurikuler. Namun hal itu tidak terlepas dari upaya pengadaan fasilitas sarana prasarana yang harus dilengkapi seperti mes perkemahan, penerangan dan wadah halang rintang. Pengadaan dan perbaikan jalur down hill run juga penting diperhatikan untuk meminimalisir resiko kecelakaan pada masyarakat. Dengan adanya wadah olahraga rekreasi akan mampu meningkatkan sumberdaya manusia yang berkualitas dan mampu menarik mata wisatawan sebagai salah satu objek daerah yang penting dikunjungi. Selain itu akan dapat memberikan lapangan pekerjaan baru bagi masyarakat sejalan dengan 
meningkatkan kualitas perekonomian masyarakat maupun perekonomian daerah.

Penulisan ini bertujuan untuk membuka mata pemerintah dalam menyalurkan atau memanfaatkan wadah yang ada di Nagari Pauah dalam mendukung pendidikan serta memberikan peningkatan perekonomian melalui pembukaan objek wisata daerah. Peluang pengadaan tempat wisata di nagari pauah dapat direalisasikan oleh pemerintah daerah dapat menjadikan Nagari Pauah Menjadi Center Objek Wisata Di Kabupaten Pasaman. Center objek wisata memberikan dampak positif dalam meningkatkan perekonomian masyarakat serta mempermudah akses pendidikan kepada generasi muda maupun masyarakat. 


\section{Daftar Pustaka}

2014. Undang-undang Republik Indonesia Nomor 3 Tahun 2005 Tentang Sistem keolahragaan Nasional dan Dilengengkapi Dengan Peraturan Pemerintah Nomor 16, 17, 18 Tahun 2007. 


\title{
BENTUK LATIHAN MENTAL DALAM PERKULIAHAN DI MASA PANDEMI
}

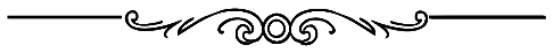 \\ Eka Kurnia Darisman, S.Pd., M.Pd.28 \\ Universitas PGRI Adi Buana Surabaya
}

"Latihan mental secara umum dilakukan dengan cara penguatan jati diri, confidence, atau hal lain yang dapat meperkuat diri sendiri dari aspek psikologis."

Pandemi Covid-19 di Indonesia yang telah berlangsung sejak pertama kali dilaporkan oleh Presiden Joko Widodo pada 2 Maret 2020 yang lalu, memiliki perkembangan yang tidak dapat diprediksi dengan pasti. Masa awal perkembangan kasus aktif dan kematian di Indonesia menunjukkan peningkatan cukup tajam. Kemudian sempat melandai dan diprediksi kegiatan pembelajaran baik di tingkat sekolah maupun perguruan tinggi akan dimulai bulan Januari 2021. Namun ternyata hal yang tidak dapat diduga sebelumnya, kasus positif dan meninggal karena Covid-19 melonjak pesat. Hal ini mengakibatkan kegiatan pembelajaran dilanjutkan dengan

28Penulis lahir di Probolinggo, pada 6 Januari 1988, penulis merupakan Dosen Prodi Pendidikan Jasmani di Universitas PGRI Adi Buana Surabaya. Penulis menyelesaikan gelar Sarjana Pendidikan Olahraga di Universitas Negeri Surabaya (2010), kemudian menyelesaikan gelar magister pendidikan olahraga Universitas Negeri Surabaya (2012), dan sejak tahun 2017 hingga sekarang menyelesaikan studi doktoral ilmu keolahragaan juga di Universitas Negeri Surabaya. Penulis merupakan pengurus APOPI dan salah satu Mental Coach dibawah APMOI.. 
menggunakan sistem pembelajaran daring (Covid19.go.id, 2020).

Upaya percepatan penanganan dari Pemerintah, untuk melandaikan grafiknya belum terlihat maksimal. Grafik fluktuatif masih terlihat dari laporan demi laporan terkait kasus Covid-19 ini. Hal yang sangat dikhawatirkan dari pandemi yang seakan tidak diketahui ujungnya ini salah satunya adalah para praktisi dan pelaku di dunia pendidikan, terutama di tingkat perguruan tinggi. Kegiatan belajar mengajar secara langsung di tingkat perguruan tinggipun ditiadakan dan untuk mengurangi kontak serta kerumunan, maka pada masa pandemi ini semua kegiatan pembelajaran dilakukan secara daring. Semua kegiatan tersebut dilakukan dan diupayakan tetap berjalan dengan melakukan berbagai macam penyesuaian.

Kuliah daring memang terlihat mudah dan menyenangkan, karena bisa dilakukan dimana saja dan kapan saja sesuai dengan keinginan. Kegiatan-kegiatan perkuliahan pun dilakukan dengan memanfaatkan aplikasi seperti zoom, skype, google classroom, microsoft team, google meet dan lain sebagainya. Bahkan tidak jarang pula perguruan tinggi memiliki e-learning tersendiri dalam sistem mereka masing-masing. Tetapi, tidak semua perkuliahan tersebut bernilai positif tanpa kendala ataupun hambatan dalam pelaksanaannya. Karena kegiatan pembelajaran berbasis internet, maka sangat tergantung pada jaringan dari masing-masing provider yang digunakan. Bukan hanya itu, lokasi domisili mahasiswa pun akan mempengaruhi seberapa jelas mereka bisa mengikuti perkuliahan daring ini. Apalagi daerah pelosok yang memiliki keterbatasan sinyal.

Tidak semua mahasiswa dan dosen merasakan menikmati kegiatan pembelajaran seperti ini. Bahkan tak 
jarang pula mahasiswa merasakan baru pertama kali melakukan kegiatan perkuliahan secara daring ini. Bisa dibilang juga mereka sebelumnya memiliki kekurangan dalam mengakses sesuatu melalui perangkat lunak seperti handphone atau laptop mereka. Hal-hal kecil yang menjadi penghambat kegiatan perkuliahan daring ini akan menjadi bom waktu yang dapat muncul sewaktu-waktu. Mengapa demikian ? hal ini dapat menjadi penyebab kejenuhan mahasiswa, yang nantinya akan berujung pada menurunnya tingkat motivasi berprestasinya.

Sebagai salah satu contoh kecil, ketika Roni (bukan nama sebenarnya) sedang mengikuti perkuliahan daring, kemudian di tengah-tengah pembahasan materi ternyata sinyal Roni menghilang, entah karena lokasi Roni yang terpencil dan sulit terjangkau sinyal, atau memang kuota internet Roni yang telah mencapai limitnya. Perasaan kesal dan jengkel akan merasuk dan berkecamuk didalam pikiran Roni. Jika hal seperti ini secara terus menerus terjadi, bukan tidak mungkin Roni akan merasakan bosan, kemudian perlahan akan berkurang motivasi belajarnya. Hal yang tidak kita inginkan pun bisa saja terjadi, yakni Roni akan berhenti kuliah karena merasa percuma mengikuti perkuliahan daring dengan segala keterbatasan dan kekurangan yang dirasakannya. Salah satu hal yang dapat dilakukan oleh seorang dosen dalam proses perkuliahan daring di masa pandemi ini salah satunya adalah dengan menggunakan latihan mental.

Berbicara mengenai latihan mental, definisi dari latihan mental sendiri adalah suatu metode latihan dimana pada suatu penugasan diimajinasikan atau divisualisasikan tanpa latihan yang terlihat secara fisik (Said \& Jannah, 2018). Bisa juga diartikan sebagai bentuk latihan jangka panjang dan sistematis untuk berkembang dan belajar 
mengendalikan tingkah laku, penampilan, emosi dan mood stress serta proses badaniah. Latihan mental biasanya dilakukan pada atlet yang memiliki target prestasi. Diperlukan karena setiap orang memiliki situasi psikologis harapan untuk sukses dan ketakutan akan kegagalan (Darisman dkk., 2021) .

Dalam kasus perkuliahan di masa pandemi ini, hasil belajar mahasiswa diibaratkan target prestasi yang harus dicapai. Sedangkan pandemi dengan Covid-19 nya adalah lawan yang perlu dihadapi. Jadi diperlukan latihan khusus yang dipersiapkan agar mahasiswa dapat mencapai target prestasi yang dicanangkan. Oleh karena itu, latihan mental termasuk salah satu bentuk latihannya. Melalui latihan mental, akibat negatif yang muncul akan lebih mudah diatasi. Latihan mental secara umum dilakukan dengan cara penguatan jati diri, confidence, atau hal lain yang dapat meperkuat diri sendiri dari aspek psikologis.

Latihan mental tidak banyak orang mengenalnya, namun jika menyebut latihan imagery, atau positive selftalk atau reframming akan lebih dikenali. Beberapa bentuk hal yang bisa dilakukan untuk menjaga kesehatan mental disaat pandemi adalah sebagai berikut:

1. Mengurangi asupan berita negatif

Membaca atau mengikuti berita memang penting, selain untuk menambah wawasan, juga agar kita tidak tertinggal informasi terkini yang ada disekitar. Tetapi jangan sampai berita yang kita ikuti menimbulkan dampak negatif kepada kita, seperti membuat cemas hingga mengakibatkan ketakutan berlebih. Terlalu banyak membaca berita dengan tema tertentu juga akan mempengaruhi kesehatan mental seseorang. Oleh karena itu, kita perlu memilah berita dari sumber yang terpercaya, paling tidak setiap 2 hari sekali. 


\section{Menghabiskan waktu bersama orang terdekat}

Dengan aktivitas yang padat sehari penuh, maka perlu menyediakan waktu untuk berkumpul dengan orang terdekat, baik itu keluarga ataupun sahabat. Bisa dengan sekedar makan siang bersama, menghabiskan waktu akhir pekan bersama, atau melakukan hal yang disukai bersamasama.

\section{Membiasakan bercerita}

Jika seseorang merasa tidak nyaman dan menganggapnya sebagai hal yang dapat mengganggu aktivitasnya, maka ceritakanlah. Bicaralah dengan orangorang yang dipercaya dan terpercaya. Baik itu keluarga, teman dekat, atau mungkin seorang psikolog. Setidaknya, dengan bercerita akan mengurangi beban dan membuat suasana hati menjadi lebih senang, lega serta nyaman.

4. Jangan mengkonsumsi alkohol atau barang lain yang menyebabkan candu

Jika berada dalam keadaan tertekan atau stress, biasanya seseorang akan melampiaskannya pada rokok atau minuman beralkohol. Bahkan bukan tidak mungkin akan menggunakan obat-obatan terlarang sebagai salah satu solusinya. Hal tersebut malah akan memperparah kondisi fisiknya, bukan malah menyembuhkan tetapi membuka peluang penyakit baru masuk kedalam dirinya.

5. Konsumsi buah dan sayur

Seperti yang tertulis dalam penelitian Warsaw University of Life Science pada tahun 2020 (Prudential.co.id, 2020) yang mengatakan bahwa konsumsi buah dan sayur dapat bermanfaat positif bagi kesehatan mental seseorang.

6. Luangkan waktu untuk berolahraga 
Sempatkan waktu setidaknya 15 sampai dengan 30 menit perhari untuk berolahraga. Dengan olahraga, kita akan merasa lebih fresh, disamping itu dengan olahraga juga akan membantu meningkatkan hubungan erat dengan orang lain, yang artinya circle pertemanannya tidak hanya golongan tertentu.

7. Lakukan hobi yang disukai

Apapun hobinya, lakukan sesuka hati. Melalui aktivitas yang disukai, pikiran akan menjadi lebih tenang, fresh, dan hatipun senang (Darisman, 2016).

Dari beberapa hal diatas, bisa menjadi contoh dan acuan yang bisa dilakukan pada masa pandemi seperti ini. Terutama bagi mahasiswa yang merasakan kejenuhan dari perkuliahan secara daring ini. Namun, ada beberapa bentuk latihan mental yang juga bisa dilakukan pada perkulihan di masa pandemi ini. Hal yang paling mudah dilakukan adalah dengan positive selftalk. Selftalk adalah ketika seseorang berusaha untuk berbicara kepada diri sendiri mengenai apapun yang dia rasakan. Sedangkan positive selftalk adalah seseorang yang sedang berbicara dengan diri sendiri dan berusaha memberikan afirmasi positif kepada dirinya agar mampu menurunkan beberapa resiko gangguan kesehatan mental (Komarudin, 2013). Hal ini bisa dilakukan dengan cara berbicara pada diri sendiri dan meyakinkan diri sendiri bahwa kita bisa melakukan lebih baik dari sebelumnya

Contoh dari positive selftalk ini adalah ketika Abdi, mahasiswa semester 5 , selalu mengalami kesulitan tiap kali perkuliahan daring berlangsung. Namun dia berusaha meyakinkan diri sendiri dan berbicara pada dirinya sendiri, "ayo Abdi, kamu pasti bisa dapat nilai tertinggi di UAS nanti, harus yakin" atau bisa juga berbicara "Abdi, targetmu mata kuliah pendidikan kesehatan sekolah adalah $\mathrm{A}$, ayo, pasti 
bisa mewujudkan!" Disamping itu, mahasiswa juga perlu meningkatkan self awareness, atau kepekaan terhadap kondisi diri mereka sendiri. Kemudian carilah dukungan dari lingkungan yang positif. Dan lakukan kegiatan yang menyenangkan ketika perkuliahan daring berlangsung (Holden dkk, 2014). Tidak perlu menuntut terlalu tinggi, berikan pengertian dan penguatan kepada mahasiwa, bahwa apa yang mereka lakukan sekarang ini sebagai wujud dari perjuangan. Sebuah perjuangan pemuda melawan rasa malas dan bosan, demi sebuah masa depan yang lebih baik, di masa pandemi ini. 


\section{Daftar Pustaka}

Covid19.go.id. (2020). Perkembangan Pandemi di Indonesia.

Darisman, E. K. (2016). Buku Ajar Sosiologi Olahraga. Unipa Press.

Darisman, E. K., Prasetiyo, R., \& Bayu, W. I. (2021). Belajar Psikologi Olahraga. Jakad Publisher.

Holden, S. L., Keshock, C. M., Forester, B. E., \& Pugh, S. F. (2014). Athlete Burnout: Is the Type of Sport a Factor? Sport Journal, 21(April 2014), 1-6. http://search.ebscohost.com/login.aspx?direct=tru $\mathrm{e} \& \mathrm{db}=\mathrm{s} 3 \mathrm{~h} \& \mathrm{AN}=98579237 \&$ site $=$ ehost-live

Komarudin. (2013). Psikologi Olahraga: Latihan Mental dalam Olahraga Kompetitif. Rosda.

Prudential.co.id. (2020). Cara Menjaga Kesehatan Mental.

Said, H., \& Jannah, M. (2018). Penentu Kemenangan, Problematika dan Solusi Mental dalam Olahraga. Unesa University Press. 


\title{
PERAN GURU DALAM MEMOTIVASI KEBERANIAN BERTANYA PESERTA DIDIK PADA PEMBELAJARAN DARING
}

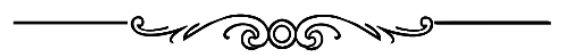

\section{Anik Widayanti E.W.T, S.Psi, M.Psi ${ }^{29}$ \\ SMAN 2 Probolinggo}

\begin{abstract}
"Peran serta Guru untuk memotivasi peserta didik agar berani bertanya kepada Guru bisa diwujudkan dengan baik selama pembelajaran daring, maka kualitas pembelajaran akan bisa didapatkan dengan mudah."
\end{abstract}

Proses pembelajaran yang ada melibatkan peran serta antara peserta didik dan Guru. Agar proses pembelajaran bisa menjadi maksimal, maka interaksi peserta didik dengan Guru perlu dijaga kualitasnya dengan baik. Untuk mewujudkan hal ini, maka perlu upaya tersendiri baik yang berasal dari Guru maupun dari peserta didik. Salah satu yang bisa mempengaruhi interaksi antara Guru dengan peserta didik adalah keberanian bertanya peserta didik. Akan tetapi keberanian bertanya peserta didik juga didukung oleh Guru terkait terutama bagaimana motivasi Guru selama proses pembelajaran. Pembelajaran selama pandemi covid 19 seperti saat ini tentunya tidak

${ }^{29}$ Anik Widayanti E.W.T lahir di Madiun, 11 Juni 1976. Penulis saat ini sebagai Guru Bimbingan dan Konseling SMAN 2 Probolinggo. Menyelesaikan gelar Sarjana Ilmu Psikologi di Universitas Muhammadiyah Surakarta (2000), Program Profesi Psikolog Universitas Muhammadiyah Surakarta (2002), Program Akta Empat STKIP PGRI Pasuruan (2004), Magister Profesi Psikologi Universitas 17 Agustus 1945 Surabaya (2013). 
bisa dilakukan tatap muka penuh, akan tetapi perlu penyikapan khusus yaitu pembelajaran secara daring. Di sinilah pemahaman pesert didik terhadap penjelasan materi pembelajaran yang disampaikan oleh Guru tentunya juga akan berbeda dalam proses penerimaannya maupun hasil yang diperoleh oleh peserta didik. Jika dibandingkan dengan proses pembelajaran yang terjadi sebelum masa pandemi covid 19. Perbedaan tersebut tentunya terkait dengan perbedaan bertemu langsung dan tidak langsung selama proses pembelajaran.

Jika pembelajaran secara langsung antara Guru dengan peserta didik maka komunikasi bisa terjadi langsung juga dan jika ada sesuatu yang kurang dipahami, maka peserta didik bisa langsung bertanya tentang apa yang belum dipahami. Tetapi jika selama proses pembelajaran tidak langsung atau dilakukan secara daring, maka situasi akan berbeda karena keberadaan Guru tidak bisa secara langsung dihadapi oleh peserta didik akan tetapi melalui alat komunikasi dalam proses pembelajarannya. Inilah kemungkinan yang berpeluang adanya permasalahan tertentu terkait pemahaman terhadap materi pembelajaran bisa saja terjadi, terutama keberanian bertanya.

Karakteristik peserta didik yang berbeda beda antara satu dengan yang lain bisa mempengaruhi besar tidaknya keberanian bertanya kepada Guru jika ada kesulitan terkait pembelajaran yang diikutinya. Jika peserta didik yang mengalami kesulitan bertanya ini tidak mendapat perhatian dari Guru, maka bisa memberi dampak yang kurang baik terhadap pemahaman materi dan yang nantinya akan berujung pada keberhasilan peserta didik dalam belajar. Kondisi ini sebaiknya bisa dilakukan sedini mungkin oleh Guru untuk bisa membantu agar peserta didik mau bertanya. Memahami keberanian bertanya oleh Guru 
kepada peserta didik juga perlu data terkait mengapa peserta didik tersebut tidak berani bertanya. Inilah saatnya Guru yang bersangkutan bisa menanyakan kepada peserta didik jika ada peserta didik yang mengalami tidak berani bertanya. Selain itu pengamatan terhadap peserta didik selama pembelajaran daring (jika dilakukan secara virtual) juga menjadi alternatif mendapatkan data. Ada beberapa kemungkinan yang bisa menjadi latar belakang peserta didik tidak berani bertanya. Adapun kemungkinan yang bisa saja terjadi tidak berani bertanya oleh peserta didik karena peserta didik sudah memahami selama pembelajaran, Untuk yang seperti ini biasanya peserta didik belum ada kemauan untuk bertanya karena dianggap materi selama pembelajaran sudah dipahami dengan baik. Dan saat itu belum atau tidak ada pertanyaan yang disampaikan kepada Guru.

Peserta didik yang selama pembelajaran tidak bertanya karena mengalami kebingungan terhadap materi pembelajaran, sedangkan mau bertanya ada perasaan malu yang dirasakan, maka ini juga akan mempengaruhi keberanian bertanya kepada Guru. Malu yang terjadi bisa saja malu bertanya kepada Guru dan tidak bisa memulai bagaimana bertanya, malu karena harus berbicara di depan teman-temannya walauun dalam daring. Atau malu karena merasa dirinya kurang mampu menyerap materi pembelajaran disbanding dengan teman yang lain. Kondisi peserta didik yang tidak ada keberanian bertanya karena rasa malas yang dialami peserta didik juga akan mempengaruhi peserta didik tidak bertanya. Berbicara rasa malas yang dirasakan oleh peserta didik, tentunya jika rasa malas ini masih dirasakan oleh peserta didik maka tidak ada kemauan untuk menanyakan sesuatu kepada Guru. Kita 
tahu malas akan menutup semua hal untuk sesuatu yang akan kita lakukan.

Ketidak beranian bertanya bisa saja terjadi karena peserta didik belum merasa perlu untuk bertanya. Nilai perlu tidaknya di sini juga membuat keputusan peserta didik untuk memilih diam dan tidak bertanya selama proses pembelajaran. Karena belum merasa penting, maka secara otomatis belum ada kepentingan untuk bertanya. Karena jika dilakukan, maka peserta didik merasa belum ada manfaat untuk didapatkan olehnya. Ketidakberanian bertanya karena ada hal sebelumnya yang membuat dirinya tidak nyaman karena bertanya juga menjadi penyebab mengapa peserta didik tidak bertanya kepada Guru. Ini kaitannya dengan kejadian tertentu yang pernah peserta didik alami sebelumnya dan masih terekam kejadian itu, sehingga jika peserta didik melakukan bertanya maka merasa akan mengaami hal yang kurang nyaman lagi sama seperti sebelumnya yang pernah peserta didik rasakan.

Alternatif atau kemungkinan tersebut di atas yang bisa menjadi penyebab peserta didik tidak berani bertanya kepada Guru selama pembelajaran daring bisa saja terjadi, maka Guru sebaiknya mencari solusi untuk peserta didik bisa keluar dari kondisi tersebut. Hal yang bisa dilakukan oleh Guru adalah dengan memberi motivasi yang dimiliki oleh peserta didik terkait dengan keberanian bertanya. Dengan adanya motivasi dari Guru kepada peserta didik diharapkan keberanian bertanya bisa muncul walaupun apa pun yang terjadi dirasakan peserta didik tidak akan menyurutkan keberanian bertanya kepada Guru. Kemampuan memotivasi peserta didik karena faktor tidak berani bertanya karena kemungkinan yang terjadi pada peserta didik sebelumnya bisa membuat peserta didik menjadi mau bertanya. Motivasi yang diberikan oleh Guru 
bisa memiliki beberapa hal latar belakang dengan memberi pengertian kepada kepada peserta didik bahwa materi pembelajaran yang sudah dipahami oleh peserta didik tidak menyurutkan peserta didik untuk udak bertanya lagi. Dengan bertanya akan ada pemahaman lebih berupa penguatan terhadap apa yang sudah diterima sebelumnya. Ini bisa ditempuh dengan cara mengajukan pertanyaan yang bersifat menguatkan terhadap materi yang diterima sehingga menjadi lebih yakin terhadap.

Memberi motivasi peserta didik untuk berani bertanya kepada Guru karena merasa kebingungan untuk memulai bertanya bisa ditempuh dengan cara memberikan kesempatan dari hal yang paling sederhana atau yang paling mudah untuk disampaikan pertanyaannya kepada Guru. Jika disertai perasaan malu untuk bertanya maka Guru bisa memulai terlebih dahulu bertanya kepada peerta didik yang seperti itu, sehingga peserta didik bisa menyampaikan pendapatnya. Atau misalnya disertai dengan perasaan malu jika berbicara di depan temantemannya walaupun pembelajaran daring, maka bisa diberi pengertian kepada peserta didik (tidak hanya yang merasakan malu tersebut) bahwa semua peserta didik sebaiknya belajar menghargai setiap ada temannya yang mengajukan pertanyaan (tidak menertawakan atau menunjukkan sikap maupun perkataan yang membuat teman yang bertanya menjadi malu bertanya) dan bertanya bukan berarti dirinya tidak mampu tetapi justru dengan bertanya akan membuat seseorang menjadi lebih memahami materi.

Memberi motivasi peserta didik untuk berani bertanya kepada Guru karena belum memahami materi pembelajran dengan cara menanyakan terlebih dulu kepada peserta didik apakah ada kesulitan selama pembelajaran daring 
akan membuat peserta didik menjawab atau berbicara untuk mengungkapkan sesuatu terkait pembelajaran yang sudah diterima. Dengan demikian membuka peluang peserta didik untuk mengajukan pertanyaan. Karena ada yang mengajak terlebih dahulu untuk membuka komunikasi atau pembicaran. Memberikan motivasi peserta didik berani bertanya kepada guru karena rasa malas yang dirasakan oleh peserta didik bisa ditempuh dengan cara memberi masukan kepada peserta didik untuk tidak mengikuti malas yang dirasakannya akan tetapi memberi pengertian dan keyakinan terhadap diri sendiri bahwa malas menghalangi untuk langkah selanjutnya. Masih ada kesempatan dan waktu yang segera dilakukan. Peserta didik agar segera membuat tujuan yang jelas, sehingga malas yang dirasakan bisa diatasi.

Memberikan motivasi peserta didik karena pernah mengalami kejadian yang kurang menyenangkan sebelumnya ketika bertanya bisa ditempuh dengan cara memberi semangat bahwa sesuatu yang sudah terjadi bisa dijadikan pengalaman untuk introspeksi diri ke depan tentang apa yang menjadikan masa lalu menjadi tidak nyaman dialami. Memberi pengertian belum tentu hal yang tidak menyenangkan akan terus menjadi tidak menyenangkan. Belajar dari sebuah pengalaman masa lalu dan bangkit dari sebuah kegagalan atau tidak mengulangi hal yang sama yang mengakibatkan kegagalan dan mempersiapkan sesuatu menjadi lebih baik bisa membuat masa selanjutnya menjadi lebih siap menjalani atau lebih baik.

Memberikan motivasi kepada peserta didik untuk berani bertanya seperti yang sudah dijelaskan di atas selama pandemi covid 19 bisa dilakukan secara daring. Jika memungkinkan untuk dilakukan secara klasikal pada saat 
pembelajaran daring tetapi jika untuk peerta didik tertentu yang tidak bisa dilakukan secara klasikal maka diperlukan dilakukan secara individual dengan cara daring. Intinya disesuaikan dengan kondisi peserta didik agar memudahkan untuk memberi motivasi secara tepat. Tidak kalah pentingnya peserta didik untuk mendukung suksesnya keberanian bertanya kepada Guru juga diperlukan partisipasi yang aktif, membiasakan diri dan memiliki semangat untuk menjadi berani bertanya agar materi yang diterima dari Guru bisa terserap dengan mudah dan jelas serta lebih dipahami. Karena jika tidak bertanya padahal ada sesuatu hal yang tidak memungkinkan untuk diikuti dengan baik selama pembelajaran daring, maka akan ada permasalahan tertentu yang dirasakan oleh peserta didik.

Peran serta Guru untuk memotivasi peserta didik agar berani bertanya kepada Guru bisa diwujudkan dengan baik selama pembelajaran daring, maka kualitas pembelajaran akan bisa didapatkan dengan mudah. Bisa kita bayangkan bahwa peserta didik maupun Guru bisa menjalani dengan suka cita dalam pembelajaran daring jika semuanyan berjalan dengan baik. Kondisi pandemi covid 19 dengan pembelajaran daring membuat semangat belajar semakin tinggi dengan hasil yang maksimal. Karena peserta didik maupun Guru sama-sama memiliki kemudahan untuk menyelesaikan permasalahan yang dialami terkait dengan materi pembelajaran. 


\section{PERSEPSI MAHASISWA PRODI PENDIDIKAN BAHASA ARAB INSTITUT AGAMA ISLAM DDI POLEWALI MANDAR TENTANG PEMBELAJARAN DARING DI MASA PANDEMI COVID-19 TA. 2020-2021

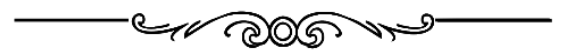 \\ Dr. Hamzah, S.S., M.Pd.I30 \\ Institut Agama Islam DDI Polewali Mandar}

"Perkuliahan daring pada hakikatnya sangat bagus dan tepat untuk dijalani saat ini terkhusus hidup dalam era industri 4.0 di abad 21 ini, dimana semua hal tidak terlepas dari digitalisasi dan orientasi pembelajaran sudah berbasis e-learning"

Cona Virus Disease atau disingkat dengan Covid-19
merupakan sebuah wabah pandemik global yang mengubah wajah baru tatanan dunia khususnya dalam beraktifitas. Dan ini menjadi sebuah penanda terjadinya babak baru tepatnya pada awal tahun 2020 yang secara global, ramai-ramai menerapkan kebiasaan baru (new normal) dalam beraktifitas yang tidak lazim seperti

30Penulis merupakan Dosen IAI DDI Polewali Mandar dalam bidang Kebahasaaraban dan Pendidikan Bahasa Arab. Kelahiran Pambusuang 05 Juli 1987. Ia meraih gelar Sarjananya pada tahun 2009 di UIN Alauddin Makassar Jur. Bahasa \& Sastra Arab Fak. Adab \& Humaniora, gelar Magisternya pada tahun 2011 di UIN Alauddin Makassar Konsentrasi Pendidikan Bahasa Arab, dan gelar Doktornya pada tahun 2019 di UIN Maulana Malik Ibrahim Malang Prodi Pendidkan Bahasa Arab dengan biaya Pemerintah Indonesia lewat program Beasiswa MORA 5000 Doktor Angkatan Kedua (2016). 
biasanya. Tak ayal, dunia pendidikan pun ikut merasakan dampaknya yang membuat sistem pembelajarannya menjadi lebih terkini (up to date) yaitu lebih mengikuti arus globalisasi digital, abad 21 dan era industri 4.0 meski belum semua pelaku pendidikan yang berada di daerah dan pelosok belum siap untuk menerapkan hal-hal yang bersifat baru dan virtualis tersebut.

Akibat dan konsekuensi dari wabah covid-19 yang sampai tahun 2021 ini masih belum bisa dipastikan redanya (meski sedang digalakkan vaksinasi covid-19) sehingga pelaksanaan pembelajaran di masing-masing satuan pendidikan termasuk di Perguruan Tinggi tanpa terkecuali masih diperpanjang untuk dilakukan secara virtual. Kondisi ini menjadi tanda tanya buramnya pelayanan pendidikan tahun ini khususnya satuan pendidikan di tingkat menengah pertama dan menengah atas seperti Madrasah Tsanawiyah (MTs) dan Madrasah Aliyah (MA) Swasta di daerah misalnya yang jauh dari perkotaan yang belum terlalu siap sarana prasarananya untuk mendukung pembelajaran daring secara virtual dan juga kurangnya SDM yang ahli di bidang IT (Hamzah R. R., 2021).

Abad 21 ini, di sisi lain memberikan pengalaman baru tersendiri dalam sebuah sistem pembelajaran yang orientasinya tidak lagi menggunakan gaya klasik satu arah dan sesuai untuk semua (direct instruction and one-sizefits-all) melainkan menyesuaikan tuntutan ke arah keseimbangan baru yang lebih bersifat interaktif (interactive exchange) yang dipersonalisasi sesuai kebutuhan (personalized) bahkan pembelajaran tidak lagi berbasis teks (text-based) melainkan berbasis web (webbased) (Bernie Trilling, Charles Fadel, 2009, hal. 38-39). Akan tetapi di sisi lain, hal tersebut belum semua satuan 
pendidikan secara merata untuk siap menerapkan dan melakoni hal tersebut di Negara Kesatuan Republik Indonesia ini. Misalnya di beberapa satuan pendidikan di wilayah Sulawesi Barat yang masih mengeluhkan hal tersebut (Hamzah R. R., 2021).

Melihat pendefenisian yang diberikan oleh Perserikatan Bangsa Bangsa (PBB) terkait pendidikan abad 21 adalah membangun masyarakat berpengetahuan (knowledge based-society) yang memiliki: 1) keterampilan melek TIK dan media (ICT and media litercy skills), 2) keterampilan berpikir kritis (critical thinking), 3) keterampilan memecahkan berbagai persoalan (problemsolving skills), dan 4) keterampilan berkolaborasi (collaborative skills) (Setyawan, 2020). Masyarakat Indonesia terkhusus pelaku pendidikan belum secara merata melek terhadap teknologi informasi (TIK), meski sudah ada yang menerapkan hal tersebut di kota-kota besar yang sarana prasarana lembaga mereka sudah mumpuni untuk hal tersebut, namun tidak sedikit lembaga lainnya yang masih ketinggalan untuk bisa menerapkan hal tersebut, tak ayal di perguruan tinggi khususnya perguruan tinggi swasta. Dan ini menjadi problem tersendiri bagi mahasiswa dan dosen yang belum terlalu piawai dalam dunia IT dan laptop.

Tulisan ini mencoba mencari tahu persepsi mahasiswa prodi Pendidikan Bahasa Arab Institut Agama Islam DDI Polewali Mandar tentang pembelajaran daring di Masa Pandemi Covid-19 Tahun Ajaran 2020-2021. Beberapa data yang sudah dikumpulkan oleh penulis melalui wawancara kepada beberapa mahasiswa prodi Pendidikan Bahasa Arab Institut Agama Islam DDI Polewali Mandar terkait penerapan pembelajaran daring di masa pandemi covid-19 
ini dengan beragam respon persepsi mereka meski bisa disimpulkan secara merata.

Penulis mencoba mengambil sampel 6 perwakilan mahasiswa dari tiap angkatan (angkatan 2017, 2018, 2019 dan 2020) sehingga berjumlah 24 perwakilan mahasiswa secara keseluruhan. Beberapa poin pertanyaan penulis yang dilayangkan kepada informan saat wawancara secara langsung adalah terkait sejauhmana efektifitas dan efisiensi pembelajaran daring yang dijalani semasa pandemi covid19, bagaimana daya serap/pemahaman terhadap materi pembelajaran, apa saja keluhan terkait proses pembelajaran daring selama pandemi covid-19, dan apa masukan buat pembelajaran selama pandemi covid-19.

Meskipun prodi PBA FTIK IAI DDI Polman sudah menerapkan pemanfaatan google suite (G-Suite) dalam sistem perkuliahannya namun belum semua dosen bisa menerapkan demikian yang terkoneksi dengan google education (Hamzah, 2021), beberapa dosen prodi Pendidikan Bahasa Arab belum semua bisa menggunakan google classroom dalam melakukan proses pengajaran, para dosen berbeda-beda dalam menggunakan aplikasi yang mendukung proses pembelajarannya secara daring. Diantara mereka ada yang menggunakan aplikasi meet google yang menurut sebagian mereka lebih ekonomis, ada juga sebagian mereka yang menggunakan aplikasi zoom meeting room karena pertimbangan sudah tersedia di handphonenya, bahkan ada juga yang masih menggunakan aplikasi whatsapp untuk memudahkan proses pengajarannya karena pertimbangan terjangkau di kalangan mahasiswa.

Dalam wawancara penulis kepada para mahasiswa, pertama; rerata mereka mengeluhkan pembelajaran daring terkait efektifitasnya yang sangat jauh dari harapan meski 
materi pembelajaran sudah tersampaikan secara daring baik diajarkan via google classroom, meet google, zoom meeting room dan via chat whatsapp. Dari 24 responden yang penulis wawancarai, $100 \%$ dari mereka menyatakan bahwa pembelajaran dengan menggunakan sistem daring kurang efektif dan kurang efisien meski aktifitas pembelajaran sudah berjalan dan materi ajar sudah tersampaikan. Mereka beranggapan bahwa perkuliahan daring belum siap untuk dilaksanakan sebenarnya, disamping kurang bersedia untuk mengikuti demikian karena hal baru, juga dosen kurang persiapan yang matang untuk melakukan perkuliahan daring, seperti penyampaian materinya yang dadakan dan masih monoton tanpa ada slide materi yang dibagikan, kurang kontrol penguasaan ruang kuliah bahkan seakan hanya memenuhi kewajiban tatap muka perkuliahan.

Kedua; terkait daya serap dan pemahaman mahasiswa terhadap materi pembelajaran yang mereka pelajari secara daring selama pandemi covid 19, dari skala 10-100\%, responden rerata menjawab daya serap dan pemahaman mereka terhadap materi ajar hanya kisaran 30-45\% pencapaiannya. Hasil ini bila ditinjau sangat miris karena sangat nampak kurang efektifitasnya perkuliahan daring yang perlu dievaluasi untuk dicarikan solusi dan alternatif agar perkuliahan ke depan bisa berjalan efektif dan efisien.

Para mahasiswa beranggapan bahwa perkuliahan daring itu terkesan hanya memenuhi tatap muka perkuliahan saja sampai batas minimal 13-14 kali pertemuan tatap muka secara virtual tanpa ada pertimbangan efektif tidaknya pemahaman mahasiswa terhadap materi ajar yang telah diajarkan oleh dosen. Sehingga anggapan sebagaian mereka sangat merugikan perkuliahan daring, disamping rugi waktu, rugi 
pembayaran dan rugi biaya kuota data karena tidak ada subsidi paket internet dari pihak kampus.

Dari segi efisiensi perkuliahan, beberapa mahasiswa yang jauh dari lokasi kampus misalnya dari daerah Kabupaten Mamuju dan kabupaten Mamasa usai wawancara kepada mereka, mereka menganggap sangat terbantukan dengan perkuliahan daring bahkan mereka memberikan skala persentasi $65-70 \%$ efisien karena bisa mengikuti perkuliahan secara daring meski begitu-begitu saja. Namun mereka juga mengeluhkan akses dan jaringan internet yang kurang kuat di sekitar tempat tinggal mereka sehingga mereka kadang asal turut hadir dan bisa mengisi absen perkuliahan daring, setelah itu mereka acuh tak acuh terhadap materi perkuliahannya.

Ketiga; keluhan terbesar dari para mahasiswa selama melakoni perkuliahan di masa pandemi covid 19 usai melakukan wawancara secara langsung adalah: 1) akses jaringan internet di daerah mereka yang masih sangat lambat, 2) kurang subsidi kuota data internet sehingga membuat mereka terkuras biaya meski sebagian dari mereka dapat subsidi kuota dari pemerintah namun tidak bisa dimanfaatkan karena kendala akses jaringan dan lain hal, 3) sarana prasarana kurang mendukung dan memadai sehingga kurang termotivasi untuk melakukan perkuliahan secara daring dan menganggap itu hanya rugi waktu dan materi, 4) dosen kurang persiapan dalam pembelajaran daring sehingga terkesan hanya memenuhi tatap muka perkuliahan dan me-list absen kehadiran, dan 5) kurang pengawasan dan kontrol ruang kelas sehingga perkuliahan monoton dan satu arah.

Keempat; adapun masukan dan permintaan yang direkomendasikan oleh para mahasiswa prodi Pendidikan Bahasa Arab kepada para pemangku jabatan khususnya 
yang ada di lingkup kampus Institut Agama Islam DDI Polman terkait tentang perkuliahan daring adalah: 1) diharapkan agar perkuliahan ke depannya bisa dilakukan tatap muka secara luring untuk dan demi efektifnya perkuliahan, 2) ada subsidi kuota dari pihak kampus kepada mahasiswa bila masih tetap menggunakan sistem perkuliahan daring, 3) diminta agar dosen pengajar ada persiapan matang, perhatian dan peduli dalam memahamkan materi ajar perkuliahan agar bisa dipahami secara efisien dan efektif materinya terkhusus kontrol perkuliahannya di ruang meeting, 4) ada kebijakan tertentu terkait kehadiran perkuliahan daring selama pandemi covid-19 bagi mahasiswa di luar daerah seperti di pedalaman kabupaten Mamasa dan kabupaten Mamuju.

Sebagai penutup dari penelitian sederhana ini, peneliti menyampaikan bahwa perkuliahan daring itu pada hakikatnya sangat bagus dan tepat untuk dijalani saat ini terkhusus hidup dalam era industri 4.0 di abad 21 ini, dimana semua hal tidak terlepas dari digitalisasi dan orientasi pembelajaran sudah berbasis e-learning (Mabruri, M., \& Hamzah, H., 2021). Namun realitas yang terjadi saat ini merupakan karena lambatnya responitas terhadap perkembangan kekinian sehingga terasa asing dan aneh saat sesuatu itu sudah saatnya untuk dijalani. Semoga adanya keluhan dan masukan dari berbagai lini itu menjadi dasar dan batu loncatan kepada para pendidik dan dosen untuk bisa lebih cepat merespon perubahan zaman, melek terhadap teknologi informasi dan jaringan minimal bisa mengoperasikan laptop dan gadget berbasis android sebab arus perkembangan zaman sudah semakin cepat terlebih masyarakat sekarang sudah beramai-ramai menjemput era society 5.0. Di samping itu, semoga pemangku jabatan di lembaga pendidikan bisa merespon cepat perubahan dan 
memenuhi kebutuhan sarana prasarana yang layak dan terkini untuk lembaga pendidikan di daerah-daerah tertinggal dan berkembang sehingga pembelajaran dan perkuliahan secara daring bisa nampak maksimal, efektif dan efisien. 


\section{Daftar Pustaka}

Bernie Trilling, Charles Fadel. (2009). 21st Century Skills: Learning for Life in Our Times. United States of Amerika: Jossey-Bass.

Setyawan, C. E. (2020). ARAH PERENCANAAN PEMBELAJARAN BAHASA ARAB ABAD 21. Journal Al-Manar, 9(1), $55-82$. https://journal.staimsyk.ac.id/index.php/almanar/ article/view/133

Hamzah. (2021). Pemanfaatan Google Suite (G-Suite) dalam Sistem Pembelajaran Bahasa Arab Fakultas Tarbiyah dal Ilmu Keguruan IAI DDI Polewali Mandar Pada Masa Pandemi Covid-19. In A. Wijayanto, Waktunya Merdeka Belajar (pp. 99107). Tulungagung: Akademia Pustaka.

Wijayanto, A. (2021, April 29). WAKTUNYA MERDEKA BELAJAR. https://doi.org/10.31219/osf.io/49q2f

Hamzah, R. R. (2021). Kreatifitas Guru Mata Pelajaran Bahasa Arab dalam Meningkatkan Keaktifan Belajar Siswa Kelas XI Siswa MA Nuhiyah Pambusuang Kecamatan Balanipa Kabupaten Polewali Mandar Pada Masa Pandemi Covid-19. Naskhi: Jurnal Pendidikan dan Bahasa Arab, 3(1), 48-56. https://journal.iaimsinjai.ac.id/index.php/naskhi/a rticle/view/557

Mabruri, M., \& Hamzah, H. (2021). The Urgency of Using Internet-Based Arabic Learning Media in Online Learning in the Global Pandemic Era. Loghat Arabi: Jurnal Bahasa Arab dan Pendidikan Bahasa Arab, $1(2)$, http://journal.ddipolman.ac.id/loghat/index.php/l oghat/article/view/6. 
$\mathrm{S}$ eiring dengan tema Hardiknas tahun 2021 maka sangat tepat apabila para pendidik atau akademisi memiliki jurus jitu untuk wujudkan proses belajar yang profesional meskipun tetap menjaga diri dari penyebaran virus corona. Akademisi sangat diharapkan memiliki kemampuan mengembangkan proses belajar secara daring di sekolah dan selanjutnya dijadikan acuan bagi anak didik dan diberi kebebasan dalam mengembangkan proses belajarnya secara mandiri di rumah sehingga target belajar yang hendak dicapai dapat terwujud, meskipun ada dugaan bahwa selama pandemi Covid-19 ini sangat mungkin terjadi penurunan kualitas anak didik karena salah satu penyebabnya yaitu masih sulitnya menciptakan proses belajar yang optimal secara daring, tanpa dipantau langsung para guru seperti proses belajar tatap muka di sekolah.

Pemikiran-pemikiran yang cerdas dari berbagai pakar pendidikan dan akademisi yang telah dijabarkan dalam tulisantulisan telah memperkaya isi buku Bunga Rampai "Akademisi dan Jurus Jitu Pembelajaran Daring" sehingga para guru sedikitbanyaknya dapat menggunakannya sebagai dasar berpikir untuk mensukseskan proses belajar daring di rumah anak didik. Selanjutnya dengan mempertimbangkan bahwa wabah pandemi covid-19 yang belum tahu pasti kapan berakhirnya, maka berbagai sumbangan pemikiran dari para pakar pendidikan yang ada dalam buku Bunga Rampai ini bisa menjadi opsi bagi para guru, anak didik, sekolah dalam mengambil kebijakan terkait proses belajar daring. Demikianlah sebagai pengantar yang menjadi dasar pemikiran betapa pentingnya buku Bunga Rampai ini untuk dibaca para guru, anak didik dan masyarakat.

\section{Akademia Pustaka}

Perum. BMW Madani Kavling 16, Tulungagung

(7) https://akademiapustaka.com/

@ redaksi.akademia.pustaka@gmail.com

(f) @redaksi.akademia.pustaka

0]@akademiapustaka

081216178398
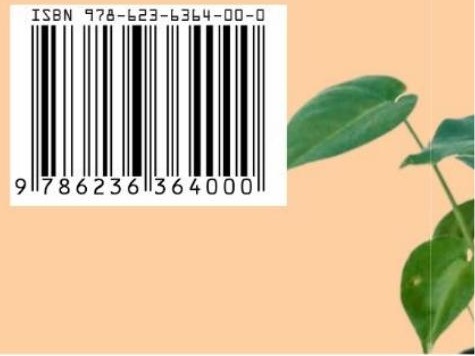